NBER WORKING PAPER SERIES

\title{
MULTILATERILISING REGIONALISM: SPAGHETTI BOWLS AS BUILDING BLOCS ON THE PATH TO GLOBAL FREE TRADE
}

\author{
Richard Baldwin \\ Working Paper 12545 \\ http://www.nber.org/papers/w12545
NATIONAL BUREAU OF ECONOMIC RESEARCH
1050 Massachusetts Avenue
Cambridge, MA 02138
September 2006

My thanks to Theresa Carpenter for excellent research assistance. The paper pulls together thinking that I have been working on since the late 1980s, so it owes tribute to virtually all of my co-authors but especially those with whom I have written on political economy theory namely my father Robert E. Baldwin, Frederic Robert-Nicoud and Rickard Forslid. I also thank the scholars who have directly contributed data, information and insights, namely Kevin O'Rourke, Doug Irwin, Bernard Hoekman, Patrick Low, Toni Estavadeoral, Olivier Cadot, Michael Gasiorek, Peter Holmes, Michel Fouquin, Gary Hufbauer, Michael Finger, Doug Nelson, Simon Evenett, Steve Charnovitz, and Alan Winters. My understanding of East Asian regionalism was greatly influenced during a 2 week visit to JETRO's Institute for Developing Economies (IDE) in January 2006, and a month long visit in 2003 to KIEP in Seoul. My thanks to my IDE hosts Masahisa Fujita and Daisuke Hiratsuka in Chiba Japan, and my hosts in Seoul Choong Yong Ahn, Hyungdo Ahn and Inkyo Cheong. The views expressed herein are those of the author(s) and do not necessarily reflect the views of the National Bureau of Economic Research.

(C2006 by Richard Baldwin. All rights reserved. Short sections of text, not to exceed two paragraphs, may be quoted without explicit permission provided that full credit, including $\odot$ notice, is given to the source. 
Multilateralising Regionalism: Spaghetti Bowls as Building Blocs on the Path to Global Free Trade

Richard Baldwin

NBER Working Paper No. 12545

September 2006

JEL No. F1, F15

\begin{abstract}
This paper addresses the final steps to global free trade -- the political economy forces that might drive them, and the role the WTO might play in guiding them. Two facts form the departure point: 1) Regionalism is here to stay; 2) the motley assortment of regional trade agreements is not the best way to organise world trade. Moving to global duty-free trade will require a multilateralisation of regionalism. The paper presents the political economy logic of trade liberalisation and uses it to structure a narrative of world trade liberalisation since 1947. The logic is then used to project the world tariff map in 2010, arguing that the pattern will be marked by fractals - fuzzy, leaky trade blocs made up of fuzzy, leaky sub-blocs (fuzzy since the proliferation of FTAs makes it impossible to draw sharp lines around the 3 big blocs, and leaky since some FTAs create free trade 'canals' linking the blocs). The paper then presents a novel political economy mechanism - spaghetti bowls as building blocs - whereby offshoring creates a force that encourages the multilateralisation of regionalism. Finally, the paper suggests three things the WTO could do to help multilateralise regionalism.
\end{abstract}

Richard Baldwin

Cigale 2

CH-1010 Lausanne

SWITZERLAND

and NBER

Baldwin@HEI.UNIGE.CH 


\title{
Multilateralising regionalism
}

\section{Spaghetti bowls as building blocs on the path to global free trade}

\author{
Richard E. Baldwin ${ }^{1}$ \\ Graduate Institute of International Studies, Geneva
}

2 October 2006; First draft: 21 June 2006

\begin{abstract}
This paper addresses the final steps to global free trade - what they might look like, what sort of political economy forces might drive them, and what the WTO might do to help. Two facts form the point of departure: 1) Regionalism is here to stay; world trade is regulated by a motley assortment of unilateral, bilateral and multilateral trade agreements; 2) this motley assortment is not the best way to organise world trade. Moving to global duty-free trade will require a multilateralisation of regionalism. This paper presents a political economy logic of trade liberalisation and uses it to structure a narrative of world trade liberalisation since 1947. The logic is then used to project the world tariff map in 2010, arguing that the pattern will be marked by fractals - fuzzy, leaky trade blocs made up of fuzzy, leaky sub-blocs (fuzzy since the proliferation of FTAs makes it impossible to draw sharp lines around the big-3 trade blocs, and leaky since some FTAs create free trade 'canals' linking the big-3 blocs). The paper then presents a novel political economy mechanism - spaghetti bowls as building blocs - whereby offshoring creates a force that encourages the multilateralisation of regionalism. Finally, the paper suggests three things the WTO might do to help multilateralise regionalism.
\end{abstract}

\section{INTRODUCTION}

This is a paper about the final steps to global free trade - what they might look like, what sort of political economy forces might drive them, and what the World Trade Organisation (WTO) might do to help. Two facts form the point of departure: 1) regionalism is here to stay. World trade is regulated by a motley assortment of unilateral, bilateral and multilateral trade agreements - a 'spaghetti bowl' of trade deals to use Jagdish Bhagwati's memorable turn of phrase. This fact is very unlikely to change. If anything, the future is likely to see the assortment getting motlier. 2) No one argues that this tangle of trade deals is the best way to organise world trade. The implication that flows from these two facts is that taking the world to global duty-free trade will require a multilateralisation of the world's existing and emerging regionalism.

The final section of the paper, Section 4, provides some thoughts on what the WTO could do to help 'tame the tangle' of free trade agreements (FTAs). To provide underpinnings for these thoughts and for the assertion that multilateralising regionalism is the way forward, the paper first presents (in Section 2) a basic political economy framework for trade liberalisation. The framework focuses on three mechanisms: the juggernaut effect for

\footnotetext{
${ }^{1}$ Presented as the 2006 World Economy Annual Lecture, Nottingham, 22 June 2006. My thanks to Theresa Carpenter for excellent research assistance. The paper pulls together thinking that I have been working on since the late 1980s, so it owes tribute to virtually all of my co-authors but especially those with whom I have written on political economy theory namely my father Robert E. Baldwin, Frederic Robert-Nicoud and Rickard Forslid. I also thank the scholars who have directly contributed data, information and insights, namely Kevin O'Rourke, Doug Irwin, Bernard Hoekman, Patrick Low, Toni Estavadeoral, Olivier Cadot, Michael Gasiorek, Peter Holmes, Michel Fouquin, Gary Hufbauer, Michael Finger, Doug Nelson, Simon Evenett, Steve Charnovitz, and Alan Winters. My understanding of East Asian regionalism was greatly influenced during a 2 week visit to JETRO's Institute for Developing Economies (IDE) in January 2006, and a month long visit in 2003 to KIEP in Seoul. My thanks to my IDE hosts Masahisa Fujita and Daisuke Hiratsuka in Chiba Japan, and my hosts in Seoul Choong Yong Ahn, Hyungdo Ahn and Inkyo Cheong.
} 
multilateral trade liberalisation, the domino effect for regional trade liberalisation, and 'race to the bottom' (RTB) unilateralism for unilateral trade liberalisation. It also covers three ancillary political economy logics that interact with the juggernaut, domino and RTB effects, namely the intra-sectoral special interest politics effect, the asymmetric lobbying effect, and the magnification of footloose-ness effect (home market effect magnification). Intra-sectoral special-interest politics explain why sectors marked by two-way trade were the first to be liberalised. Asymmetric lobbying effects explain why losers lobby harder and thus why the threat of trade diversion creates such powerful pro-liberalisation forces. The magnification of footloose-ness explains why nations are so eager to sign FTAs with big nations when tariffs are already so low. To establish the framework's usefulness, Section 2 also employs the framework to organise a line-sketch of post-war trade liberalisation. Taking this historical narrative as a rough test of the framework's usefulness, the Section then goes on to predict the world tariff map in 2010.

A novel political economy mechanism - what might be called the 'spaghetti bowls as building blocs' mechanism - is presented in Section 3.2.3 and used to argue that systematic political economy forces may push the world up the last two steps to global free trade. The basic idea is that production unbundling (also called fragmentation, vertical specialisation, or slicing up the value added chain) tends to turn the former beneficiaries of spaghetti-bowl complexity into victims; 'us' becomes blended with 'them' and this creates a mild political economy force that favours a taming of the tangle, i.e. a multilateralisation of regionalism.

\section{The literature}

The literature that is relevant to this paper is too vast to review in any detail; it includes contributions by authors in economics, political science and international law. Political scientists who have recently written in this area include Keohane (2002) and Destler (2005), with Milner (1988), Gilligan (1997), and Destler and Odell (1987) being the classics. Jackson $(1997,2000)$ and Charnovitz $(2002,2005)$ are examples on the legal side. When it comes to economics, it is useful to divide the studies into two types. Some are written for the broad audience of economic actors, policy makers, and their staffs; these aim to help them organise their thinking about the complex world. Others are written for professors and students of economics specialising in international trade; these aim to meticulously working through the logic of precisely but narrowly defined problems. Several surveys of the latter are available, especially noteworthy being Panagyriya (2000), Bagwell and Staiger (2002), and Yamamoto (2002). It is also important to cite Bill Ethier's writings (Ethier 1998a, b) on the interactions among unilateralism, regionalism and multilateralism as his papers span the two types. It is much harder to find a good synthesis of the broadaudience literature, in part because the literature is evolving so rapidly in response to the radical developments the world has seen in the past five years. For example Winters (1996), Panagyriya (1999) and World Bank (2000) are excellent stocktakings, but they pre-date the cascade of East Asian FTAs and the new phenomenon of cross-bloc FTAs. The thinking in the present paper is most closely related to the notion of 'competitive liberalisation' by Fred Bergsten in, for example, Bergsten (1998). The insightful thinking and writing of Jagdish Bhagwati are both incredibly influential in shaping the thinking in this paper and too numerous to cite, except perhaps the landmark essay Bhagwati (1994) entitled "Regionalism and multilateralism."

\section{POLITICAL ECONOMY LOGIC OF TRADE LIBERALISATION}

This section presents a framework for organising thinking about trade liberalisation. Before turning to the theory, it sets out the facts to be explained by outlining the basic elements of post-war tariff liberalisation.

\subsection{Then and now: Trade $\&$ tariffs, 1950 vs 2005}

The 1930s were dark years for the world trade system. When WWII started, tariffs everywhere were high and trade had collapsed to 70\% of it 1928 level (Anderson and Norheim 1993). The US's 1930 Smoot-Hawley tariff had sparked tariff wars and defensive trade blocs (Kindleberger 1989) with Germany, Italy, Japan and the Soviet Union leading trade blocs with explicitly autarkic aims and militaristic motivations. Small European nations formed the Oslo group, and Britain and France leaned on their empires with attendant tariff preferences. 
How different things are today. A great deal of world trade is duty-free and tariffs average less than $4 \%$ on the bulk of the remaining trade (WTO 2005). Of course a large number of economically small nations maintain high tariffs and tariffs are still substantial on a few low-volume items in the major trading nations, but neither exception makes much difference on the global scale. For this reason, the paper largely ignores issues raised by the trade of small nations (those whose imports constitute less than a half of one percent of world imports), highly protected but low-volume goods such as sugar and dairy products, and small inter-regional and intra-regional trade flows (those below $2 \%$ of world trade). Space limitations dictate this choice, but this important omission deserves to be remedied in future work.

\subsubsection{World trade patterns: 1950 versus 2003}

World trade in 1950 is hardly recognisable from today's perspective, as can be seen from the regional groupings that GATT (1953) chose to illustrate the network of world trade in its first statistical publication (Table 1). Most of today's nations were colonies and the commercial importance of Britain and her empire was still very much in evidence. The US and UK were pitted against each other in the GATT and this struggle threatened, at times, to throttle the GATT in its infancy. (The US pressed for the dismantlement of Britain's system of Imperial Preferences and Britain insisted on lower US tariffs against British goods, Zeiler 1997). Just one of the many features of Table 1 that seems odd from today's perspective is the fact that Britain's exports to the Dominions and colonies exceeded US exports to all of Continental Europe. The table also shows that trade and currency blocs were very much one in the same in 1950.

Table 1: Network of world trade, 1951.

\begin{tabular}{|c|c|c|c|c|c|c|c|c|c|c|c|}
\hline & $\begin{array}{l}\text { Continental } \\
\text { Western } \\
\text { Europe }\end{array}$ & $\begin{array}{l}\text { North } \\
\text { America }\end{array}$ & $\begin{array}{l}\text { Overseas } \\
\text { Sterling } \\
\text { Area }\end{array}$ & $\begin{array}{l}\text { European } \\
\text { Sterling } \\
\text { Area }\end{array}$ & $\begin{array}{l}\text { Rest } \\
\text { of the } \\
\text { World }\end{array}$ & $\begin{array}{l}\text { Dollar } \\
\text { Latin } \\
\text { America }\end{array}$ & $\begin{array}{l}\text { Other } \\
\text { Latin } \\
\text { America }\end{array}$ & $\begin{array}{l}\text { W. } \\
\text { European } \\
\text { colonies }\end{array}$ & $\begin{array}{l}\text { Communist } \\
\text { nations }\end{array}$ & Japan & World \\
\hline Continental Western Europe & $11 \%$ & & & $3 \%$ & $2 \%$ & $0 \%$ & & $2 \%$ & & & $23 \%$ \\
\hline North America & $4 \%$ & $7 \%$ & & & & $4 \%$ & & & & & $22 \%$ \\
\hline Overseas Sterling Area & $3 \%$ & $3 \%$ & $3 \%$ & $5 \%$ & & & & & & & $16 \%$ \\
\hline European Sterling Area & $3 \%$ & & $5 \%$ & & & & & & & & $12 \%$ \\
\hline Rest of the World & $2 \%$ & & & & & & & & & & $8 \%$ \\
\hline Dollar Latin America & & $3 \%$ & & & & & & & & & $6 \%$ \\
\hline Other Latin America & & $2 \%$ & & & & & & & & & $6 \%$ \\
\hline W. European colonies & $2 \%$ & & & & & & & & & & $4 \%$ \\
\hline Communist Nations & & & & & & & & & & & $3 \%$ \\
\hline Japan & & & & & & & & & & & $0 \%$ \\
\hline Total World & $28 \%$ & $21 \%$ & $14 \%$ & $13 \%$ & $8 \%$ & $5 \%$ & $4 \%$ & $4 \%$ & $2 \%$ & $0 \%$ & $100 \%$ \\
\hline
\end{tabular}

By 1963, the European Economic Community (EEC) was in business, and Britain had formed the European Free Trade Association (EFTA) and applied to join the EEC. Many of Britain's colonies were independent nations that had raised tariffs against British manufactured goods (Findlay and O'Rourke 2007 Chapter 9). Rich nations were growing fast while poor nations were struggling to keep up or actually falling behind. In particular, Europe enjoyed spectacular GDP growth rates and North American was close behind. This brought the world trade pattern much more in line with today's pattern. As the left panel of Figure 1 shows, in 1963 there were two 'hubs' - North America and Western Europe. A large fraction of world trade was either within or between these two hubs. The flows between the hubs and the various 'spokes' - Latin America, Africa, the Middle East, Asia and Japan - were small; there was no significant trade among the spokes.

This pattern evolved little over the subsequent half century with one major exception - the emergence of Asia. Japan's trade grew to over 5\% of the world total and this was followed by the emergence of China and rapid growth in intra-Asian trade. Today Asia accounts for about a quarter of world trade. Trade within and between Western European and North American nations still accounts for about two-fifths of world trade, but by 2003 Asia clearly constitutes a third hub. 
Figure 1: World direction of trade, 1963 and 2003.

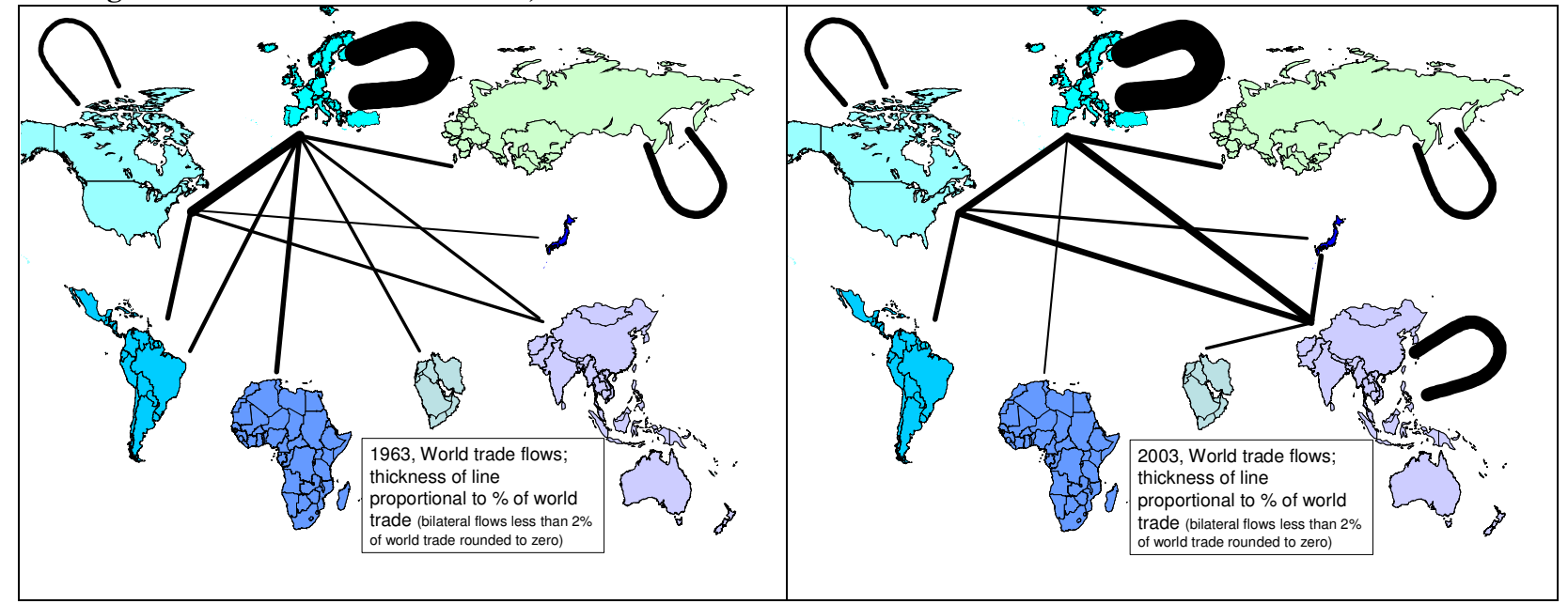

Note: The left panel show world trade flows in 1963; the thickness of lines indicates the bilateral flow's share of world trade (flows less than $2 \%$ are rounded to zero for clarity). The right panel shows the same for 2003.

Source: WTO (2004), GATT (1986,Table A.13).

Table 2: Tariffs 1931 to 2000, Europe and North America (Findlay and O'Rouke 2007).

\begin{tabular}{|c|c|c|c|c|c|c|c|}
\hline & 1931 & 1950 & $\begin{array}{l}\text { Early } \\
1960 \mathrm{~s}\end{array}$ & 1976 & $\begin{array}{l}\text { Mid- } \\
1980 \mathrm{~s}\end{array}$ & 1990 & 2000 \\
\hline European Average & 30.4 & 17.8 & 14.0 & 8.9 & 6.6 & 8.3 & 4.2 \\
\hline Greece & & 39 & & & 7 & 8 & 4 \\
\hline Germany & 18 & 26 & 13 & 9 & 7 & 8 & 4 \\
\hline Italy & 42 & 25 & 13 & 9 & 7 & 8 & 4 \\
\hline United Kingdom & & 23 & 18 & 9 & 7 & 8 & 4 \\
\hline Austria & 28 & 18 & & 12 & 9 & & 4 \\
\hline Portugal & & 18 & & & & 8 & 4 \\
\hline France & 29 & 18 & 13 & 9 & 7 & 8 & 4 \\
\hline Belgium & 13 & 11 & 13 & 9 & 7 & 8 & 4 \\
\hline Netherlands & & 11 & 13 & 9 & 7 & 8 & 4 \\
\hline Norway & & 11 & & 9 & & 7 & 3 \\
\hline Sweden & 24 & 9 & & 6 & 5 & & 4 \\
\hline Denmark & & 3 & & 9 & 7 & 8 & 4 \\
\hline Spain & 76 & & & & & 8 & 4 \\
\hline Finland & 23 & & & 13 & & & 4 \\
\hline Switzerland & 22 & & & 4 & 3 & & \\
\hline N. American Average & 37 & 15 & 17 & 12 & 7 & 8 & 4 \\
\hline Canada & & & & 13 & & 11 & 5 \\
\hline United States & 37 & 15 & 17 & 11 & 7 & 6 & 4 \\
\hline
\end{tabular}

Notes: See Findlay and O'Rourke for details on data sources and construction; generally the figures represent simple averages.

Source: Findlay and O'Rourke (2007 Table 9.1).

\subsubsection{Tariffs}

Protection levels were still quite high in the late 1950s, although lower than they were in the 1930s. In 1950 the average tariff was $18 \%$ in Europe and $15 \%$ in North America (Table 2). It is important to note, however, that quantitative restrictions - often imposed for balance of payments reasons - were frequently the binding constraint on trade, especially in Europe. By 2000, when most of the Uruguay Round cuts had been phased in, tariffs where much lower, averaging about $4 \%$ in the North Atlantic nations. Tariffs in the rest of the world also started high in the early 1960s (roughly before the GATT got really serious about tariff cutting in the Kennedy Round) and have come down since. As inspection of the table shows, Japan's tariffs have come down to under 3\%, but many other nations in Asia and elsewhere maintain levels of protection between 10 and 15\% (Table 4). 
Table 3: European \& US tariffs, 1958, Selected manufactured goods

\begin{tabular}{llllllll}
\hline \hline & Benelux & France & W. & & & \\
& Germany & Italy & EEC6 & UK & US \\
\hline Instruments & 13 & 22 & 8 & 17 & 16 & 27 & 29 \\
Footwear & 20 & 21 & 10 & 21 & 19 & 25 & 19 \\
Clothing & 20 & 26 & 13 & 25 & 21 & 26 & 32 \\
Furniture & 13 & 23 & 8 & 21 & 17 & 20 & 24 \\
Building parts \& fittings & 15 & 19 & 8 & 25 & 17 & 15 & 20 \\
Transport equipment & 17 & 29 & 12 & 34 & 22 & 25 & 13 \\
Electric machinery & 11 & 19 & 6 & 21 & 15 & 23 & 20 \\
Machinery other than electric & 8 & 18 & 5 & 20 & 13 & 17 & 12 \\
Manufactures of metal & 11 & 20 & 10 & 23 & 16 & 21 & 23 \\
Iron and steel & 5 & 13 & 7 & 17 & 10 & 14 & 13 \\
Non-Metallic mineral manuf. & 12 & 16 & 6 & 21 & 13 & 19 & 13 \\
Textiles & 14 & 19 & 11 & 10 & 16 & 23 & 26 \\
Paper, Paperboard & 14 & 16 & 8 & 18 & 15 & 13 & 10 \\
Wood Manufactures & 11 & 19 & 7 & 22 & 16 & 15 & 18 \\
Rubber Manufactures & 17 & 17 & 10 & 19 & 18 & 21 & 18 \\
Leather & 11 & 11 & 12 & 18 & 12 & 16 & 16 \\
Chemicals & 7 & 16 & 8 & 17 & 12 & 15 & 24 \\
\hline \hline
\end{tabular}

Note: Benelux (Belgium, Netherlands and Luxembourg) had formed a customs union in 1947.

Source: El-Agraa (1994), Table 3.24

Table 4: Tariffs 1960s to 2000, Other nations (Findlay and O'Rouke 2007).

\begin{tabular}{|c|c|c|c|c|}
\hline & Early $1960 \mathrm{~s}$ & Mid-1980s & 1990 & 2000 \\
\hline Asian Average & 31 & 33 & 21 & 9 \\
\hline Indonesia & & 24 & 19 & 9 \\
\hline Philippines & 46 & & 20 & 7 \\
\hline Taiwan & 30 & & 10 & 6 \\
\hline Thailand & & & 41 & 16 \\
\hline China & & 41 & 43 & 16 \\
\hline Korea & & & 13 & 8 \\
\hline Japan & 18 & & 4 & 3 \\
\hline \multicolumn{5}{|l|}{ Other Nations } \\
\hline Brazil & 99 & 44 & 35 & 17 \\
\hline India & & 80 & 84 & 32 \\
\hline New Zealand & & & 9 & 3 \\
\hline Mexico & 22 & 17 & 14 & 17 \\
\hline Nigeria & & & 36 & 26 \\
\hline
\end{tabular}

The figures in Table 3 show European and US tariffs on a range of items for 1958, the year the EEC started to form its customs union. US tariffs were generally above the level of EEC6 tariffs. The UK's tariffs were close to the US levels and often higher. From today's perspective, it is striking that these key Anglo-Saxon nations maintained higher tariff levels than Continental Europeans. European regional integration had only just begun and the four GATT Rounds had cut tariffs only modestly.

As Table 5 shows, in 2002 the simple average was $4 \%$ for the US, EU and Japan and somewhere between a quarter and two-fifths of their industrial tariffs were bound at zero. The story is quite different, however, for agriculture and textiles and clothing. In the US, EU, Japan and Canada, the bound rates for textile and clothing are roughly twice the average. The gap is even larger for agricultural goods; Japan's bound tariffs are seven times higher in food than manufactures, for the EU and Canada the figure is four times, and for the US it is twice. The gap between bound and applied rates is relatively modest. 
Table 5: Tariffs in rich and poor nations, circa 2002

\begin{tabular}{lcccccccc}
\hline & & & & & & & \multicolumn{3}{c}{ South } \\
Duty free (\% of tariff lines) & US & EU & Japan & Canada & China & Indonesia & Chile & Africa \\
\cline { 2 - 9 } Simple average bound rate & 38 & 28 & 41 & 30 & 8 & 2 & 0 & 10 \\
Agricultural, bound & 5 & 6 & 8 & 8 & 10 & 38 & 25 & 21 \\
Industrial, bound & 8 & 16 & 27 & 23 & 15 & 47 & 26 & 47 \\
Textile and clothing & 4 & 4 & 4 & 6 & 9 & 36 & 25 & 18 \\
Simple average applied rate & 9 & 8 & 7 & 12 & 12 & 29 & 25 & 27 \\
Agricultural, applied & 5 & 6 & 7 & 7 & 12 & 7 & 6 & 11 \\
Industrial, applied & 10 & 16 & 19 & 21 & 18 & 8 & 6 & 12 \\
Textile and clothing & 4 & 4 & 4 & 4 & 11 & 7 & 6 & 11 \\
\hline \hline
\end{tabular}

Notes: Bound rates are "final bound rates" from the Uruguay Round, Applied from 2002. Source: WTO Annual Report, 2003, Chapter 2.

For developing nations, taking China, Indonesia, Chile and South Africa as representative, the bound rates are much higher than those for rich nations. The straight average for industrial bound tariffs of the four poor nations is $22 \%$, fives times that of the rich nations. The developing nations' bound rates are also higher for food than manufactures (34\% versus 19\% taking the simple average), but the gap is no where near as high as it is for rich nations. The developing nations have bound very few items at zero. One striking aspect of the figures in Table 5 is the divergence between the bound and applied rate for developing nations. For example the average applied rate on industrial goods is only $50 \%$ higher for the poor nations versus the rich nations in the table. For developing nations, it seems that unilateral and regional liberalisations have been the main modalities for tariff cutting and these cuts have not be bound in the multilateral setting.

\subsubsection{Sevenx stylized facts about post-war tariff liberalisation}

For what follows, it is useful to simplify the main trends in post-war liberalisation into stylised facts:

1. The GATT process started when tariffs were very high worldwide;

2. Rich nations liberalised much more than poor nations in both the GATT process (i.e. bound rates) and RTAs;

3. The liberalisation focused on industrial goods in which two-way trade in similar goods is prevalent;

4. The process took 40 years;

5. Some sectors were excluded entirely and others experienced much less tariff cutting;

6. Regional tariff cutting went hand-in-hand with multilateral liberalisation.

7. Unilateral liberalisation was important in developing nations from the mid 1980s.

The next task is to organise the historical narrative around a handful of political economy mechanisms. This is meant to imbue the political economy logic with some credibility so that it may be used to predict the future. But before telling the story of post-war trade liberalisation, the next section presents the political economy logic to be employed.

\subsection{A Political economy framework}

This paper assumes that tariffs are the endogenous outcome of an interaction between a nation's economy and its political system. ${ }^{2}$ From this political economy perspective, trade liberalisation is a puzzle. Why would nations find it politically optimal to reduce tariffs that they had previously found optimal to impose ${ }^{3}$ This section considers mechanisms that help answer the 'liberalisation puzzle.' It starts with the basic lobbying model of tariff choice.

\footnotetext{
${ }^{2}$ See Baldwin (1976) for an early view and Hillman (1989) for a review of the main approaches, and Grossman and Helpman (2002) for mathematical refinements of several of the basic approaches.

${ }^{3}$ See Baldwin and Baldwin (1996) for an early treatment of the political economy of endogenous trade liberalisation.
} 


\subsubsection{Political economy of tariff choices ${ }^{4}$}

According to the political economy approach adopted in this paper, a tariff is chosen to balance the supply and demand for protection in the political market much as a price balances supply and demand in a competitive market. Walrasian supply curves are marginal cost curves, so by analogy the supply of protection is the marginal cost to the government of imposing a tariff, where the cost is in terms of damage to the economy as measured by simple utilitarian indicators. Walrasian demand is the marginal utility curve, which by analogy becomes lobbying expenditures by import-competing firms which are linked to the marginal benefit of tariffs, i.e. their impact on operating profit.
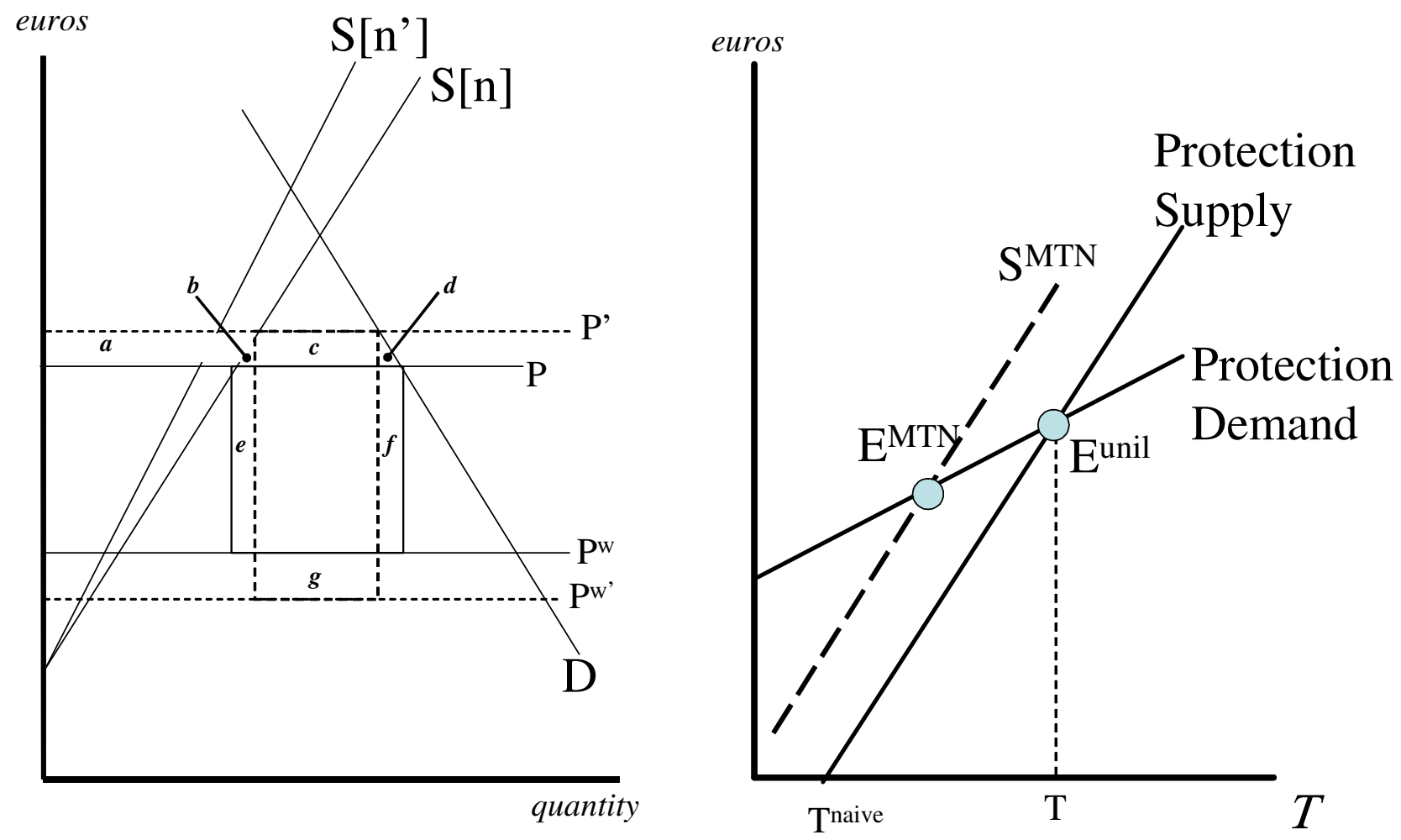

Figure 2: Supply and demand for protection, unilateral case.

To understand the basic determinants of the supply and demand for protection, Figure 2 shows how various players are affected by a tariff change ( $\mathrm{T}$ is the specific tariff). Consider first the impact on national welfare, taking the sum of consumer surplus, producer surplus and tariff revenue as the metric. A marginal tariff hike lowers consumer surplus (-a-b-c-d), raises producer surplus $(+a)$ and changes tariff revenue $(+c+g-e-f)$ with the net effect being $-(e+f)+g$ as shown (minus the triangles $b+d$, but these are second-order small for marginal tariff changes). While this net will be positive at very low tariff levels, it eventually becomes negative since imports fall as the tariff rises, with imports eventually reaching zero at the prohibitive tariff. To reflect this, the Protection Supply curve in the right panel intersects the y-axis below zero since the 'naïve optimal tariff' (i.e. the optimal tariff assuming the government is a welfare maximiser) is positive for any nation that has any market power in any market and it is positively sloped since the welfare cost of a marginal tariff hike is increasing in the tariff level beyond the naïve optimal tariff.

I may be losing it but in your welfare analysis in figure 2 surely the

$>$ net welfare effect is $-(e+f+b+d)+g$ ? It is not clear to me why the

$>\mathrm{H}$-triangles (areas $\mathrm{b}+\mathrm{d}$ ) disappear in your calculation, unless areas e and

$>\mathrm{f}$ are defined to include $\mathrm{b}$ and $\mathrm{d}$, respectively.

${ }^{4}$ For a more formal treatment of this, see the original treatments by Findlay and Wellisz (1982), Baldwin (1985); Grossman and Helpman (1994) or reviews in Hillman (1989); see Baldwin and Robert-Nicoud (2006) "Protection for sale made easy" for a simplified presentation of Grossman and Helpman (1994). 
$>$

The demand for protection stems from import-competitors' marginal gains (+a) and this increases with $\mathrm{T}$ since a higher tariff means higher output and this means there will be more to protect on the margin. To reflect this, the 'Protection Demand' in the right panel intersects the y-axis above zero (the marginal increase in producer surplus is positive even at a zero tariff assuming the nation produces some of the good at world prices) and it is positively sloped since the domestic supply curve is rising. The politically optimal tariff is defined at the intersection of the supply and demand curves. ${ }^{5}$

\subsubsection{Juggernaut \& MTNs}

There are several models of how Multilateral Trade Negotiations (MTNs) affect tariffs. The juggernaut approach is employed here. ${ }^{6}$

Starting from an initial situation where tariffs are chosen unilaterally as in Figure 2, announcement of an MTN based on the principle of reciprocity alters the array of political forces inside each and every nation participating in the talks. Reciprocity is the key. It converts each nation's exporters from bystanders in the tariff debate to opponents of protection within their own nation. Exporters can win the prize of better access to foreign markets only if tariffs in their home nation are lowered, so lobbying against domestic tariffs becomes a way of lowering foreign tariffs. The marginal impact of a lower foreign tariff on national welfare is illustrated in the left panel of Figure 3. Lower foreign tariffs raise the price facing domestic-based exporters. This lowers domestic consumer surplus by A and raises producer surplus by $A+B_{1}$. Even if the profits of exporters are not over-represented in the political economy system, this will raise the marginal cost of protection. In terms of the Figure 2 framework, reciprocal trade talks shift the supply of protection upwards as shown in the right panel by the curve marked $S^{\mathrm{MTN}}$. To put it differently, the MTN changes the political objective function facing all governments. ${ }^{7}$ The result is that now all nations participating on the basis of reciprocity find it politically optimal to cut tariffs somewhat. This is the first part of the juggernaut logic.

This first step in the juggernaut framework has long been recognised in histories of trade liberalisation. ${ }^{8}$ While this basic point has been expressed in many forms, it may be useful to think of the MTN's reciprocity as solving the 'political economy externality' faced by all governments. Governments know that freer trade would be better for their nation, but they know it would be difficult to muster a political coalition for unilateral liberalisation (Hufbauer, Erb and Starr 1980). The novel aspect of the juggernaut idea lies in its view of liberalisation as a dynamic process. Explaining this requires an additional element of political economy logic.

The additional element plays on the fact that the politically optimal tariff depends upon the size of the export and import-competing sectors. If there are many active firms in the import competing sector, then the marginal benefit of a tariff hike is greater in the unilateral case. Likewise the size of the gain to the export sector from an MTN tariff cut depends upon the size of the export sector. But what determines the number of firms in the import and export sectors? To start with, consider only the number of firms in the import competing sector.

In the simplest case, we assume firms have identical (rising) marginal cost functions and the fixed entry cost is rising in the number of firms, i.e. the long-run supply curve is more elastic than the short-run curve. That is to say, a drop in the domestic price will lead to the exit of some import-competing firms, so the domestic supply curve will

\footnotetext{
${ }^{5}$ Microfoundations for this approach can be found in Baldwin (1987) and Grossman and Helpman (1994).

${ }^{6}$ The standard account of multilateral liberalisation starts from the prisoner's dilemma. Optimal tariff arguments, the standard account asserts, lead nations to pursue terms-of-trade gains in an uncoordinated manner and the result is high tariffs all around. Because terms-of-trade battles are worse-than-zero-sum, Pareto-improving cooperation is possible and this is why the GATT succeeded. This traditional view might be called the GATT-as-coordination-device model of trade liberalisation. The Bagwell and Staiger (1999) view of the GATT refines this standard view by restricting outcomes to cooperation that is self-reinforcing, i.e. a subgame perfect equilibrium in a repeated game with various punishment strategies. This standard view surely constitutes the deep fundamentals of the GATT's success; as a matter of pure logic, mutual gains from cooperation must be at the heart of any successful agreement between sovereign nations. This story, however, fails to account for many stylised facts listed above. Baldwin (1994 Chapter 2.5.2) introduced the juggernaut effect.

${ }^{7}$ See Baldwin and Robert-Nicoud (2006) for a formalization based on the protection-for-sale (PFS) framework. When tariffs are unilaterally chosen, the government's objective function was a weighted sum of welfare (consumer and producer surplus and tariff revenue in the import competing industry) and contributions of the import-competing firms. Export producer surplus mattered but since it was unaffected by the tariff (first-order approximation), it was a constant and thus dropped out of the government's first order condition. With the MTN, exporter producer surplus becomes a function of the domestic tariff (since the foreign tariff is a function of the domestic tariff under reciprocity), so the government's first order condition gets an extra term in the welfare element, and if the exporters are politically organized, there is an extra term in the contributions sum. Both of the extra terms are negative (welfare and contributions fall more for any marginal tariff increase under the MTN versus unilateral case).

${ }^{8}$ For relatively recent examples see Hoekman, Bernard and Kostecki, Michel (2001), Baldwin (1984). The basic idea dates much further back as Irwin (1996) points out. Even more recently, its logic has been studied formally in precisely defined settings by Grossman and Helpman (2001), and Bagwell and Staiger (2002).
} 
rotate counter-clockwise. This is shown in the left panel of Figure 2 by S[n']. Tracing out the full graphical impact of the lower number of firms (from $n$ to n') would clutter the diagram excessively, but it is easy to see that the welfare impact would remain as before, $-(\mathrm{e}+\mathrm{f})+\mathrm{g}$, but the demand for protection would rotate in since the marginal impact of a tariff hike on import-competing profits would be smaller for any given level of $\mathrm{T}$.

Turning this around, the impact of higher tariffs will now be twofold. Higher tariffs will raise the number of firms, but the higher number of firms will in turn raise the politically optimal tariff. To find the equilibrium, we fold the politically optimal tariff choice into a single curve - called the GFOC since it is the solution to the government's first order condition - and we add a free entry curve - FE - that relates the equilibrium number of firms to the tariff. This is shown in the right panel of Figure 3.
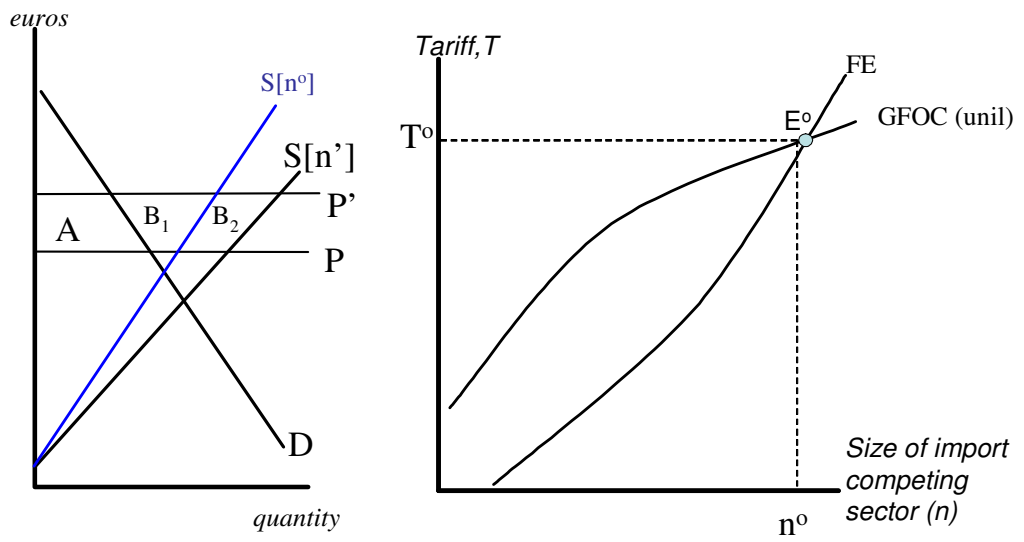

Figure 3: Juggernaut framework

The diagram in Figure 3 forms the backbone of our historical narrative in the next section, so it is worth discussing a number of its features. The horizontal axis plots the number of firms in the import-competing sector. This number is determined by a free entry condition (the basic distinction is the difference between the short-run and long-run supply curves in a Walrasian model), i.e. ' $n$ ' is a function of the tariff. On the vertical axis is the tariff, T, and this is determined by the solution to the government's first order condition - GFOC - when it optimises a 'politically realistic objective function' of which the Grossman-Helpman approach is one example. ' The GFOC in the unilateral case is marked GFOC (unil). The intersection of GFOC (unil) and FE gives us the combination of $\mathrm{n}$ and $\mathrm{T}$ where the government is choosing the politically optimal tariff taking $\mathrm{n}$ as given and firms enter up to the point of zero pure profits taking $\mathrm{T}$ as given. The equilibrium is marked as $\mathrm{E}^{\mathrm{o}}$. It would be useful to have the equilibrium number of firms in the export sector in the same diagram as well, but this is not possible in two dimensions since the free-entry number of firms in the export sector depends upon the foreign tariff rather than T. ${ }^{10}$ See Staiger (1995), Bond and Park (2002), Zissimos and Lockwood (2004), and Chisik (2003) for related explanations of gradualism.

\section{Reciprocal trade talks and the juggernaut effect}

The two elements above, Figure 2 and Figure 3, allow graphical presentation of the two steps of the juggernaut effect. To illustrate it, consider the impact of the announcement of reciprocal trade talks on the politically optimal tariff in all participating nations. As discussed above, the MTN re-arranges the political economy forces inside each participating nation in a way that raises the marginal cost to the government of maintaining any given tariff level (taking as given the number of firms in the import-competing sector). In the right panel of Figure 2, this appears as a shift up in the supply of protection curve. In the right panel of Figure 3, it shows up as a shift down of the GFOC curve since the government finds it politically optimal to set a lower tariff for any given level of $\mathrm{n}$. This is illustrated in the left panel of Figure 4. The new long run equilibrium is E', but since entry and exit occur slowly, the tariff and state of the import-competing industry do not jump to E'. Telling a simple version of the dynamics, the reciprocal

\footnotetext{
${ }^{9}$ Figure 2 took some elements of the government's first order condition and called them the marginal political cost of protection (supply) and took other elements and called them the marginal political benefit of protection (demand). The intersection is the graphically solution since this is where the sum of all elements equals zero.

${ }^{10}$ Plainly general equilibrium effects are ignored as in Grossman and Helpman (1994); while these are surely important, they are second order when it comes to the political economy of tariffs for major industrial nations.
} 
trade talks result in an instantaneous drop in the tariff to $\mathrm{T}_{1}$. This liberalisation induces some import-competing firms to exit (and some export firms to enter but this is not shown in the diagram). The state of the economy eventually reaches $\mathrm{A}$, at which point another reciprocal trade talk with the same partners would result in another tariff cut, this time to point B. That is, given the smaller size and thus smaller political influence of the importcompeting sector, and the larger size and thus larger political weight of the export sector in all nations, the participating nations would find it politically optimal to cut their tariffs reciprocally to the point B. And the cycle repeats itself until the new long run equilibrium $E^{\prime}$ is reached.
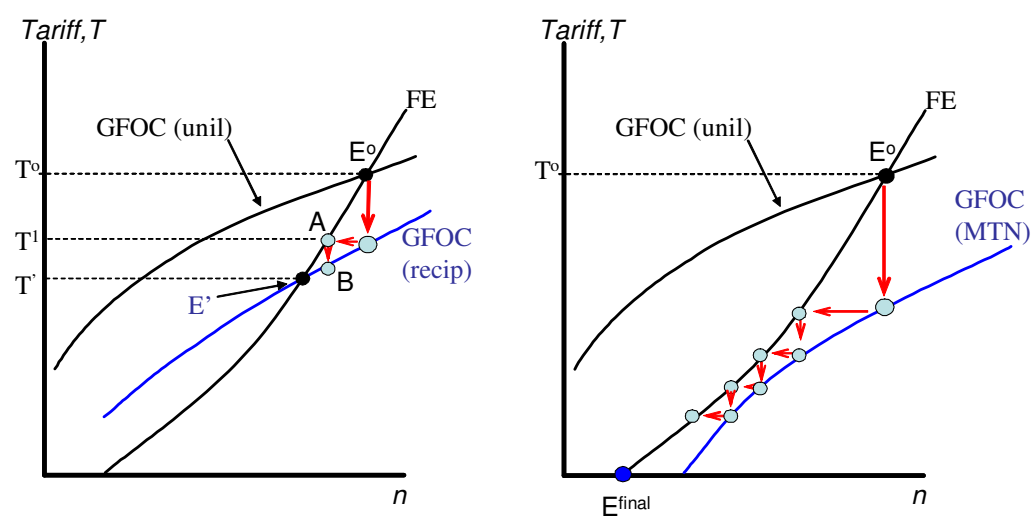

Figure 4: Juggernaut effect and MTNs

The left panel of Figure 4 shows the situation when the reciprocal trade talk covers either only some of the nation's trade partners, or only part of the goods exported. The right panel shows the situation when all trade is covered. ${ }^{11}$ Here the shift down in GFOC is large enough to ensure that the long-run equilibrium involves zero tariffs as shown by point $E^{\text {final }}$. The stylised adjustment process, shown by the series of dots and arrows, gradually leads all participating nations to free trade.

\section{Intra-sectoral special interest politics}

The juggernaut approach in its simple form works best when the export firms and the import-competing firms are in different sectors. Much of the post-war trade liberalisation, however, has been of industries marked by two-way trade in similar products. In industries such as transport equipment, chemicals and electrical machinery, the exporting firms and the import-competing firms are all producing similar goods. One problem is that the standard framework for understanding this intra-industry trade - what is often called the new trade theory - does not mesh well with the juggernaut theory. In the most common version of the new trade theory (the Dixit-Stiglitz version of Helpman and Krugman 1985), reciprocal liberalisation does not raise profits of exporting firms. The point is that firms lose in the domestic market what they gain in the export markets. In the oligopoly version of the theory (Brander and Krugman 1983, Markusen 1981) the profits of all firms fall in all markets since the extra competition narrows price-cost margins via a pro-competitive effect. In either case, it is hard to understand why exporters would fight for trade liberalisation.

To understand juggernaut liberalisation of intra-industry trade, it is necessary to reach for the very latest trade theories, the so-called new-new trade theory (Melitz 2003, Eaton, Kortum and Kramarz, 2004). These models allow for differences in firm size and efficiency and explain why the largest, most efficient firms export while smaller firms sell only domestically. In addition to matching many important aspects of reality, this implies that there is what might be called 'intra-sectoral special interest politics'. In the new-new trade models, reciprocal trade liberalisation raises the profits of big export firms while lowering the profit of small firms in the same industry that sell only in the local market (Falvey, Greenaway and Yu 2004, Baldwin and Forslid 2004). The intuition is simple. Reciprocal liberalisation harms small firms that sell only locally since it raises the degree of competition they face; they have no exports to benefit from the expanded foreign market access. This leads to a downsizing of such firms

\footnotetext{
${ }^{11}$ See Baldwin and Robert-Nicoud (2005) for a formal example that shows a full MTN leads to full liberalization. The basic reason turns on the fact that total production of a nation's export sectors exceed the production of its import-competing sectors (the former produce for domestic and foreign consumption while the later only cover part of domestic consumption). Since lobbying contributions are proportional to output, the export sectors win the battle for free trade.
} 
with some of them exiting the industry. For the big firms, by contrast, the extra competition at home is offset by better market access abroad. On net they gain since their sales benefit from the downsizing and exit of small firms in both markets. Turning from the economic impact of reciprocal liberalisation to the political economy aspect, the key fact is that there are many more small firms than big firms. Thus, Olsen's Asymmetry suggests that industries engaged in intra-industry trade will tend to be pro-liberalisation. ${ }^{12}$ Notice the juggernaut's liberalisation-begetsliberalisation features of this mechanism. Big exporting firms drive the liberalisation of sectors marked by intraindustry trade since they are better organised politically than the small firms in the same sector, and the liberalisation itself downsizes the anti-trade small firms while upsizing the pro-trade big firms. ${ }^{13}$

\subsubsection{Dominos \& PTAs}

Preferential trade liberalisation has been a key element in post-war trade liberalisation, so a political economy framework for understanding such preferential liberalisation is necessary. Here the domino theory of regionalism is employed. $^{14}$

The domino theory starts with a positive model of membership in a preferential trade arrangement (PTA) and proceeds in two stages - the immediate impact of an idiosyncratic deepening of integration in the PTA, and the knock-on impact implied by bloc-enlargement. To start with the positive model, the assertion is that a nation's decision to join a PTA is determined by its domestic political equilibrium that balances pro-membership and antimembership forces. The theory associates the pro-joiners with the nation's exporters that gain from preferential access if the nation joins and suffer from discrimination if the nation stays out. The anti-membership political economy forces are associated with the import-competing industries that would lose from the liberalization that membership would imply as well as non-economic objections to membership. Consumers and taxpayers are taken as interest groups of second-order importance for the usual "Olsen's Asymmetry" reasons.

Given an initial political equilibrium membership in the PTA, an idiosyncratic shock that deepens the PTA's integration generates new political economy forces in non-member nations as non-member exporters now have a greater stake in membership - they face more discrimination if their nation stays out and greater market access if it joins. Anti-membership forces are also strengthened in non-member nations as the liberalization implied by membership is heightened. If the industrial output of export sectors is systematically larger than the output of import-competing sectors (as is usually the case since the export sector produces for both domestic and foreign consumers) and a sector's political power is linked to its size, the shock raises the pro-membership forces more than the anti-membership forces. For outsiders that were previously close to indifferent to membership (politically), these changes shift the domestic political economy equilibrium to the pro-joiner camp.

The second stage starts if one non-member actually does decide to join. The PTA enlargement implies that discrimination facing the remaining non-members expands and this again heightens the pro-membership political economy forces in outsiders, potentially producing a membership application from an outsider that previously found it politically optimal to stay out. The cycle repeats itself until a new political equilibrium membership in the PTA obtains.

If the world was marked by perfect information and synchronized periodicity in political decision-making, PTA membership bids would be perfectly coordinated and bloc enlargement would happen in a step-like fashion. Uncertainty, imperfect information and mis-matches of decision timings suggest that the new political economy equilibrium may be reached only gradually. During the transition it might look like regionalism was spreading like wildfire.

\footnotetext{
${ }^{12}$ Olsen's asymmetry (from Mancur Olsen) stresses the fact that the losers from protection are hard to organise politically since they are many in number, geographically disperse, and lose little from each tariff, while the gainers from protection (import-competing firms) are few in number, often geographically concentrated and gain enormously from individual tariffs.

${ }^{13}$ The mechanism is first discussed in Baldwin (2000). Baldwin and Robert-Nicoud (2005) work out a more formal model. Bombardini (2004) applies the new-new trade theory to endogenous lobbying formation.

${ }^{14}$ The idea underlying the domino mechanism is an old one. A version can be distilled from Jacob Viner's account of how dozens of German principalities and citystates were cajoled and coerced into joining Prussia's Zollverein (Viner 1950 Chapter V.3). More recently, Whalley (1993) also views Western Hemispheric regionalism as largely defensive (rather than US-led). He, however, focuses on fears of US protectionism instead of trade diversion, and he does not posit a circular causality between bloc size and the strength of inclusionary pressures. Hufbauer (1989) uses the term "FTA magnetism" which captures the first step (idiosyncratic deepening sparks membership requests) but does not relate the strength of the magnetism to the bloc size. The formal model of the domino theory of regionalism was first presented in Baldwin (1993a) which was published as Baldwin (1995). See Baldwin (1994, 1997, 2002, 2006) for applications it to European, Western Hemisphere and Asian domino effects.
} 
The domino effect can be illustrated in Figure 5. The EE curve shows how the pressures to join rise as membership in the bloc expands (the pressure is measured in dollars since this is the change in the governments objective function with and without membership). The RR curve shows the intrinsic resistance of nations to joining the bloc, arranging nations from those with the lowest resistance to those with the highest. Under easy regularity conditions, $\mathrm{EE}$ and $\mathrm{RR}$ intersect at $\mathrm{E}^{\mathrm{o}}$ and this determines the equilibrium bloc membership. A deepening of integration in the block will rotate EE up and this results in a new political economy equilibrium at E'. The arrows suggest a simple dynamic story of how some nations apply to join, and their decisions to join trigger membership requests from nations that previously found it politically optimal to stay out.

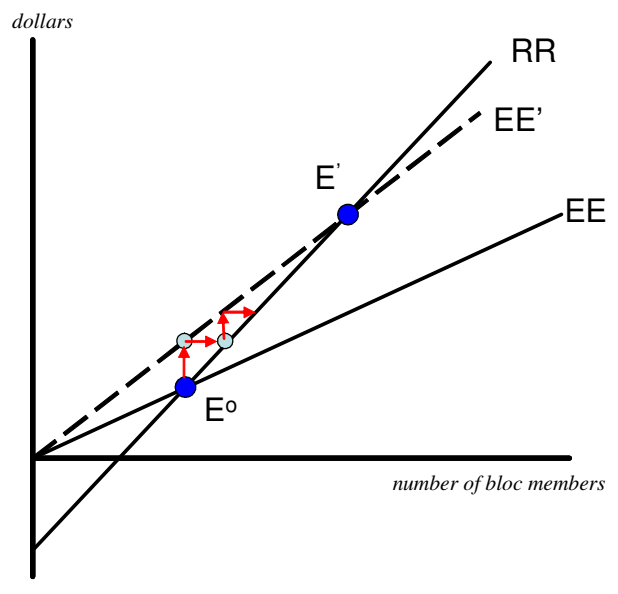

Figure 5: The domino theory of regionalism. Source: Baldwin (1993 Figure 1).

\section{The supply side of PTA membership}

So far there has been no mention of the 'supply side' of membership - i.e. thinking about whether the incumbents would allow the applicants to join. This is not an omission but rather a strategic choice of the domino theory, and thus a limitation. Many theorists since Krugman (1993) have viewed the equilibrium bloc size as an exercise in terms-of-trade exploitation, so the economic interest of the incumbent PTA members must be a key issue in the determination of bloc size. While such considerations may play a role, the domino theory asserts that it is a secondary role that can be ignored for the sake of parsimony. The justification for this bold assumption lies in observation of real-world PTAs. For example, in the case of the EU (which accounts for $40 \%$ of world trade) membership is explicitly open to all European nations that meet the so-called Copenhagen membership criteria (these have nothing to do with terms of trade effects). In the case of the US, the initial reluctance to expand the list of bilateral FTAs beyond Canada and Mexico has eroded recently. The US now seems ready to offer an FTA to almost any nation, provided of course, that the partner is willing to accept the US template FTA which involves a great deal of market opening in sensitive areas including agricultural markets, intellectual property rights, and services. In Asia, the big nations - Japan, China and Korea - seem ready to negotiate with all comers and the small player - ASEAN - has in fact led the region in FTAs. Plainly the supply-side of membership might be critical in some regions of the world, so we should view this omission as a strategic simplification that trades-off clarity for completeness. See Aghion, Antras and Helpman (2004) for a careful treatment of the supply and demand for membership in a cooperative game theory framework. They formally prove that almost anything can happen; in particular that the domino effect is one possible outcome even when the supply side is considered. ${ }^{15}$

\section{Asymmetric lobbying}

The political economy forces driving the domino effect are strengthened by the peculiar tendency of special interest groups to fight harder to avoid losses than to secure gains. Joining allows excluded firms to avoid damages

\footnotetext{
${ }^{15}$ For other game theoretic foundations, extensions and modifications of the domino theory see Bond and Syropoulos (1996), Freund (2000), Yi (1996), Mclaren (2002), Levy (1997), and Krishna (1998).
} 
as well as to win new commercial opportunities, so trade diversion may play a particularly important role in generating new, pro-membership political economy activity. Many explanations for this 'loser's paradox' are possible, but one simple economic interpretation that is relevant to the domino theory is based on unrecoverable investments, i.e. sunk costs. Entry into most industries and markets involves large unrecoverable investments in product development, training, brand name advertisement and production capacity. In such situations, established firms can earn positive profits without attracting new firms, but only in so far as these profits constitute a fair return on the entry investments, i.e. sunk costs create quasi-rents, not pure rents. Given that firms in an industry will have already incurred the sunk costs, deepening of an existing bloc, or formation of a new one will destroy quasi-rents, and thus generate strong, de novo political forces pushing the government to redress the new discrimination. The most direct way would be to join the bloc, but other modalities are possible. Government of excluded nations may seek to restore quasi-rents by calling for a multilateral trade round, or forming a new trade bloc among excluded nations. ${ }^{16}$

\subsubsection{How dominos can start the juggernaut rolling}

Since the formation of the EEC in 1958, RTAs and MTNs have proceeded in tandem, so it is useful to connect RTA liberalisation and MTN liberalisation in a simple analytic framework. Figure 5 serves the purpose.

The free entry schedule in Figure 3 was drawn assuming that there was only one foreign nation and thus only one domestic tariff. When one allows two trade partners, an RTA with one of them will shift the FE curve to the left. The argument is simple. The relationship shown by FE gives $n$ as a function of the MFN tariff rate T. But a preferential tariff cut that boosts the nation's imports from the preferred partner will imply that domestic firms face a higher degree of competition for any given level of the MFN tariff. Consequently, a schedule relating the MFN tariff to $\mathrm{n}$ will shift when tariffs are cut preferentially. The shift, from FE to FE' in Figure 5, depicts the situation where the preferential liberalisation has increased the domestic economy's total imports. Notice that in this case, the RTA would change the politically optimal MTN tariff from $\mathrm{E}^{\circ}$ to E'. Or, to use Jadish Bhagwati's memorable phrase, trade blocs would be building blocks.

Viner's ambiguity, however, tells us that an RTA may instead lower the amount of imports (and thus competition in the import substituting sector) that corresponds to a given MFN tariff; in this case, the FE curve would shift the other way, from FE to FE". The result would be that trade blocs are stumbling blocs, i.e. that the politically optimal MFN tariff is higher after the bloc. Notice however, that if MTN reciprocity is sufficiently strong, MTNs will grind the MFN tariff to zero $\left(\mathrm{E}^{\mathrm{final}}\right)$ regardless of whether the RTAs are trade creating or trade diverting; this is shown in the right panel.
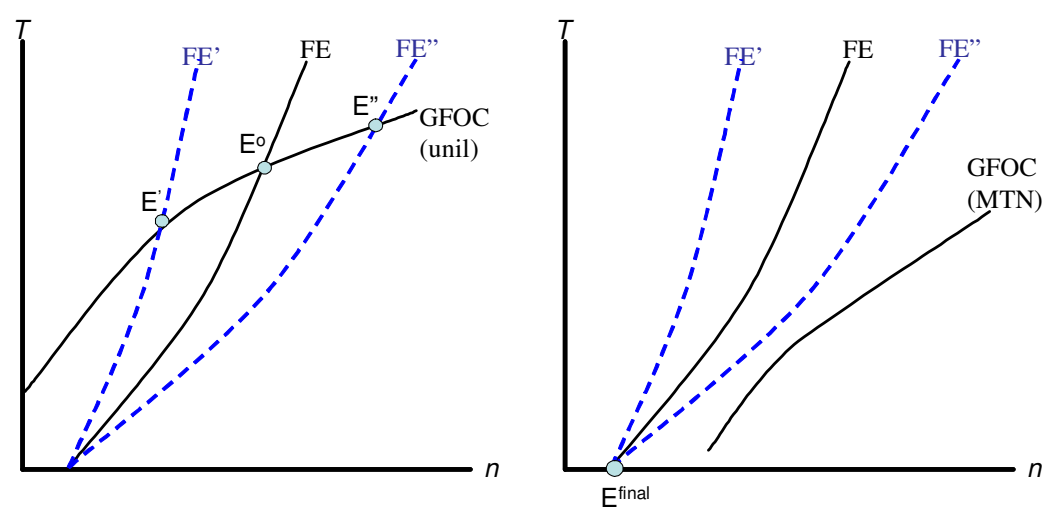

Figure 5: Dominos start Juggernauts

\subsubsection{Race-to-the-bottom unilateralism}

Trade liberalisation of the main world trade flows (see Figure 1) has taken the form of regionalism or multilateralism. In recent years, however, many developing nations have begun cutting their tariffs unilaterally.

${ }^{16}$ See Baldwin and Robert-Nicoud $(2002,2005)$ for a formal treatment of the ideas and Baldwin (1993b) for an early formal model. 
Indeed, most of the rapid expansion of trade in East Asia has been fostered by unilateral trade liberalisation rather than preferential trade liberalisation. From the perspective of endogenous trade policy, unilateral tariff cutting is a challenge since one must explain why it became politically optimal to remove a tariff that was previously politically optimal to impose; neither domino nor juggernaut effects will do. To account for this requires a third political economy logic. Since the logic takes its inspiration from the public finance theory of race-to-the-bottom tax competition, it could be called 'race to the bottom (RTB) unilateralism.'

Following the success of Japan and the four-tigers (Korea, Taiwan, Singapore and Hong Kong), many developing nations pursued 'dual track' development strategies that blocked the imports of manufactured goods for final consumption while simultaneously fostering manufactured exports (Greenaway, Morgan and Wright 2002). The strategy fit in well with the global trend towards the 'unbundling' of manufacturing processes, what has sometimes been called fragmentation, or slicing up the value-added chain (Grunwald and Flamm 1985, Krugman 1995, Ng and Yeats 2003). Rising rich-nation wages and the rapid fall in trade and communications costs meant that firms that had previous bundled together most or all stages of manufacturing in one nation now found it profitable to unbundled and off-shore some stages (especially labour-intensive stages) to nations whose low productivity is more than offset by their low wages. Since there where many low-wage nations ready to welcome the off-shored jobs and investment, locational competition among these nations resulted in, inter alia, low tariffs on the imported intermediates. In some cases, this consisted of 'duty drawbacks' and duty-free treatment for plants located in Export Processing Zones, but as the complexity of unbundling grew and timeliness in production became a key competitive factor the cumbersome duty-drawback system was switched to low or zero MFN applied rates.

The political economy of these tariff cuts are completely different to those discussed in Figure 2. Since the tariffs apply to imported intermediate inputs which are typically only available abroad, there was little or no importcompeting industry to harm with lower tariffs. Moreover, since the tariff cuts were viewed as critical to creating new industry jobs, unilateral tariff cutting became politically optimal, especially when other low-wage nations started doing it.

\subsubsection{Home market magnification effect}

The next piece of analytics concerns the common misperception that low tariffs make market access less of an issue. For example, WTO (1995 p.56), after noting that the Uruguay Round greatly lowered tariffs in rich nations, writes: "These MFN tariff reductions have diminished considerably the incentive to obtain preferential market access in developed country markets." Given the plethora of North-South FTAs that world has seen in the last decade, something must be wrong with the WTO's logic. The answer is called the 'Home market magnification effect.' In plain English it explains why industry becomes more footloose in a world of low tariffs, not less.

Krugman (1980) demonstrated the now-famous Home Market Effect which explains how trade costs and scale economies combine to give large markets a disproportionate share of world industry. The standard intuition for this result is that firms seek to locate production in the big market in order to minimise trade costs. This explanation seems to suggest that the effect would get weaker as trade costs (including tariffs) become less important. This is wrong, but explaining why requires some background.

Figure 6 shows the determination of the location of industry in a two nation world. ${ }^{17}$ Initially nations are the same size and trade costs are equal so the obvious outcome is symmetry, i.e. the number of home firms, $\mathrm{n}$, and foreign firms, $\mathrm{n}^{*}$, are equal. The point $\mathrm{A}$ is defined by the intersection of the two free entry conditions, marked $\mathrm{FE}_{\mathrm{H}}$ and $\mathrm{FE}_{\mathrm{F}}$ and it is the equilibrium since each nation's industry is in equilibrium taking as given the other nation's n. Home's free entry condition is downward sloped in the diagram since a drop in the number of home-based firms would require an increase in the number of foreign firms in order to restore zero profits. Moreover, the trade-off is not oneto-one since trade costs mean that competition is localised to some extent. Due to trade costs, the degree of competition from local firms is greater per firm than the degree of competition from firms based abroad. This is why a drop of $\mathrm{n}$ by one unit, requires an more than one unit increase in $\mathrm{n} *$ to restore the free entry equilibrium in the home economy. A similar effect works in the foreign economy. Its free entry condition, $\mathrm{FE}_{\mathrm{F}}$, is also negatively sloped but its slope exceeds unity since a one-unit drop in $\mathrm{n}^{*}$ requires a more than one unit rise in $\mathrm{n}$ to push foreign profits back to zero. The pair, $\mathrm{n}$ and $\mathrm{n}^{*}$, is where both free entry conditions are satisfied.

${ }^{17}$ The figure assumes industry is marked by increasing returns and Dixit-Stiglitz monopolistic competition. 
Given this set up, consider the impact of making the home market a bit larger and the foreign market a bit smaller. This change will, if $\mathrm{n}$ and $\mathrm{n}$ * stay at the symmetric level, create pure profits in the home economy since the home based firms will now be able to service a larger share of their customers without trade costs. The home free entry condition must shift out therefore to, say, the dashed line; it will require some combination of more home firms and/or more foreign firms to restore profits to zero in the home market. Likewise, the foreign free entry condition must shift in since foreign-based firms now face worse market access than before; they have to incur trade costs to sell to a larger share of their customers than before so their profit becomes negative. This means the new $\mathrm{FE}_{\mathrm{F}}$ is shifted in since it requires some combination of lower $n$ and/or lower $n^{*}$ to restore zero profits in the foreign market. The equilibrium, point $\mathrm{B}$, is marked by a rise in $\mathrm{n}$ and a fall in $\mathrm{n} *$. The shift in firms exceeds the shift in market size - that is the home market effect. Note that in this exercise, the shock is a change in market size, but the key is market access. A similar shifting of firms would occur even with equal size nations, if home unilaterally raised its tariffs and foreign did not retaliate. ${ }^{18}$

Consider the impact of globally lower trade costs (say lower MFN tariffs in home and foreign) in this framework. Lower trade costs mean that local competition and foreign competition are more similar, so the slopes of the free entry conditions approach minus one. In the extreme of no trade costs, the competition from firms located at home, namely $\mathrm{n}$, is identical to the competition from firms located in foreign, namely $\mathrm{n}^{*}$, so both FE schedules have a slope of minus one. A near-free-trade situation is shown in the right panel of Figure 6 . In the perfectly symmetric case, the lower trade costs have no impact on the location of industry, but if home improves its market access - say the home market gets bigger and the foreign market smaller, the FE curves shift as before and $n$ rises while $n^{*}$ falls. The important point is that the shift in industry from foreign to home is larger for any give change in market access when trade costs are lower. This is the home market magnification effect. It implies the somewhat counterintuitive results that small changes in relative market access have larger effects on the location of industry when trade costs are low. Or to put it colloquially, firms get more footloose in a globalised world, not less.

As far as trade policy is concerned, this means that small advantages created by tariffs matter more when the overall level of protection is low. For example, preferential market access to the EU's or US's markets means more in 2006 when worldwide MFN tariffs are low, than it did in 1990 when MFN tariffs where higher. This goes some way to explaining why the grinding down of MFN tariffs in the post-war period did not dampen the domino effect. ${ }^{19}$
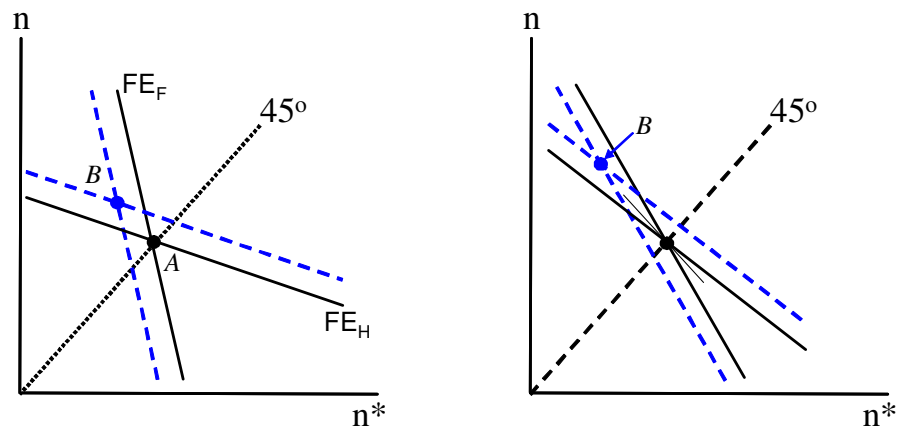

Figure 6: Home market effect and its home market magnification effect

The next task is to use the three main effects, juggernaut, domino and RTB unilateralism, to organise thinking about how tariffs were liberalised in the post-war world.

\subsection{The historical narrative}

The GATT was set up to reduce tariffs on trade and it did its job. The full story of how five decades of MTNs and RTAs liberalised tariffs would fill a bookshelf. The goal here is to structure the historical narrative using the three

\footnotetext{
${ }^{18}$ See Baldwin, Forslid, Martin, Ottaviano and Robert-Nicoud (2003) Chapters 12, 13 and 14 for the formal analysis.

${ }^{19}$ See Baldwin (2000, p. 239) for an early application of the home market magnification effect to the political economy of trade liberalization.
} 
political economy effects from above. The exercise may have some merit in its own right, but the main purpose for this paper is to boost confidence in the three effect's relevance to real-world events.

\subsubsection{Domino and juggernauts}

The history of the world's post-war trade liberalisation begins in 1934. Regretting its burst of protectionism, the US Congress authorised the US President to cut tariffs via the Reciprocal Trade Agreements Act of 1934. This authorised the US administration to negotiate item-by-item tariff cuts on a reciprocal basis (primarily bilateral). It is hard to find consistent global data on tariffs, but US data is available and the US was a vital player in the post-war trade system, so US data is taken as indicative. ${ }^{20}$ Figure 7 shows the US average tariff on dutiable imports from 1920 to 1996.

The 1934 Act switched the US from a unilateral tariff setter to a reciprocal trade talker. As per the juggernaut theory, this rearranged political economy forces inside the US in a way that lowered the politically optimal tariff. As the tariffs of US and its partners fell, anti-trade forces grew weaker and pro-trade forces stronger. This industrialrestructuring-re-negotiating dynamo rolled forward slowly. As can be seen from the figure, it took a couple of decades to reach the new political economy equilibrium. The vehicle for implementing the new political equilibrium was the Hull Trade Pacts in the first instance and the GATT in the second (the 1934 Act is what authorized the US to bargain in the first five GATT Rounds). The basic assertion here is that the item-by-item reciprocity did not realign US political economy forces enough to make free trade politically optimal.

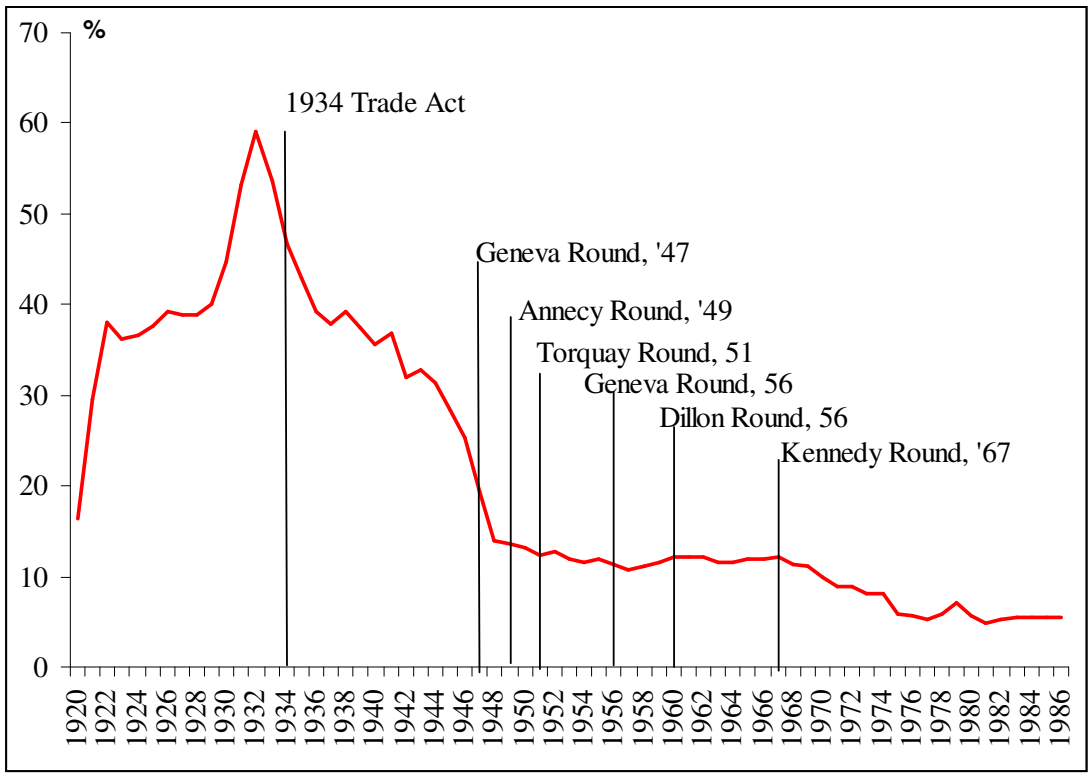

Figure 7: US tariffs 1920 - 1986.

Note: Average tariff on dutiable imports.

Source: Source: Historical Statistics of the United States, Colonial Times to 1970.

The 1950s political economy equilibrium was not to last, however. European dominos started the juggernaut rolling anew in the early 1960s. Michael Finger has pointed out several important problems with using the Figure 7 data; see

\section{Box 1: Issues with the average tariff data}

Michael Finger pointed out that as regards Figure 7 one has to be careful in using the duties collected to dutiable imports as an indication for the evolution of tariffs. For example, if liberalization cuts nuisance tariffs to zero, the average of duties to dutiable imports could rise when the previously low duties and their imports drop out of the numerator and denominator. He notes, the share of dutiable trade in total US imports is changing sharply in post

${ }^{20}$ See the appendix figure Figure 14 for EU average tariff data from 1971 to 2003 . Thanks to Michael Finger for this data. 
WWII period which makes this indicator less reliable. "This change is linked to the large structural change in US imports with a rise in the share of (finished) manufactured goods which do not enter duty-free and face on average a much higher tariff than agricultural products and raw materials as well as ores and metals. The ratio of duties collected to imports is therefore affected by these structural shifts. Commodity price changes affect the ratio too." The main differences between the ratio of duties to total imports and the figures shown in Figure 7 are first, the level of the average tariff is much lower and two, the US tariff appears to rise between 1950 and 1970. See Appendix Figure 15 for the full figures provided by Michael Finger.

He also notes a further reservation concerning the use of tariff averages as an indicator of protection levels. Given the wide range of protectionist instruments available to nations, using the tariff levels to reflect a nation's trade policy stance demands some qualification. Non-tariff barriers vary considerably over time and across nations and we do not have good estimates of their protectionist impact for all the years and nations under study. Moreover, one cannot hope that these other restrictions evolved at the same speed and in the same direction as tariff levels.

In bilateral communication with the author, Finger writes: "On the importance of tariffs in the late 1940s I found a revealing comment in the Economist (November 22, 1947, p. 827) after the creation of GATT and the conclusion of the first GATT round: "....that for many countries -and not least for the UK- customs tariffs are at present without any influence on the volume of trade." Foreign exchange restrictions, quantitative restrictions including many import and export bans, state trading and licensing requirements had been widespread. The GATT Secretariat issued between 1950 and 1952 four reports on quantitative or discriminatory restrictions and none on tariff levels. Only in 1953 it released tariff levels estimates for 1952."

In the 1980's the re-emergence of the so-called VERs and the rise of contingent protection all this is not reflected in the tariff average. At the same time, the important preferential tariffs in the case of regional integration in North America and Western Europe are not reflected in the MFN bound and applied tariff rates."

It is exactly this sort proviso that dictates the focus on tariffs in this paper. This is a serious omission that will hopefully be redressed as more data emerges.

\section{8-1958 Regionalism begins to liberalise \& European Domino effect: Phase I}

While the GATT brought down tariffs worldwide, the European arrangement set up by the Marshall Fund - the Organisation for European Economic Cooperation (OEEC) - liberalised trade in Western Europe. Of particular note were the European Payments Union (EPU) and the EPU/OEEC's 'Code of Liberalization'. The former removed the necessity for balance-of-payments linked quotas and the latter required members to lower trade barriers by 25 per cent. Intra-European trade doubled from 1950 to 1958; imports from North America grew only 50\%. Europeans, especially the Six (Germany, France, Italy and the Benelux nations), tried various forms of tighter integration most notably the successful European Coal and Steel Community (ECSC) and the failed European Political Community (EPC) and European Defence Community (EDC). None of these had much impact on trade, but all that changed in $1957 .^{21}$

The 1957 Treaty of Rome launched the European Economic Community (EEC), but given the EPC and EDC failures, the signing did not trigger a domino effect - that came when the Six moved rapidly from words to action in setting up their customs union. Due to the impeding discrimination, the US and UK found it politically optimal to engage in pro-trade initiatives that they had previously found politically optimal to resist. Britain led the 1960 formation of a trade bloc (EFTA) among other excluded Western European nations, and then applied to join the EEC in 1961. Why would Britain, who had found it politically optimal to stay out of the EEC in 1957, find it politically optimal to apply in 1961 ? The domino theory's answer is that the impending trade diversion and missed opportunity of trade creation re-aligned British pro- and anti- membership forces. As a result, the pro-joiners gained the upper hand in the British political system. Britain's application triggered a domino effect of its own. Ireland, Norway and Denmark, nations that had seen fit to stay out of the EEC in the 1957, all put in applications soon after Britain did since they found it politically optimal to join an EEC that included Britain when they found it politically optimal to stay out of the EEC6.

\section{2-1967, RTAs force an MTN, dominos start juggernaut cycle II}

\footnotetext{
${ }^{21}$ See chapter 1 of the textbook Baldwin and Wyplosz (2006) for details.
} 
North America sent a third of its exports to Europe and the high European tariffs suggested that the trade diversion effect could be large. The US had to react. US membership in the EEC was out of the question, so the US sought to redress the discrimination in a very different way. In 1961, President Kennedy started moves to secure Congressional authority for negotiating down the EEC's Common External Tariff in the GATT. The GATT-EEC link is explicit in Kennedy's "Special Message to the Congress on Foreign Trade Policy," January 25, 1962; here is the first of "five fundamentally new and sweeping developments [that] have made obsolete our traditional trade policy" (i.e. the $1934 \mathrm{Act}$ ) which he used to argue for a stronger form of reciprocity: ${ }^{22}$

" The growth of the European Common Market - an economy which may soon nearly equal our own, protected by a single external tariff similar to our own - has progressed with such success and momentum that it has surpassed its original timetable, convinced those initially skeptical that there is now no turning back and laid the groundwork for a radical alteration of the economics of the Atlantic Alliance. Almost 90 percent of the free world's industrial production (if the United Kingdom and others successfully complete their negotiations for membership) may soon be concentrated in two great markets - the United States of America and the expanded European Economic Community. A trade policy adequate to negotiate item by item tariff reductions with a large number of small independent states will no longer be adequate to assure ready access for ourselves - and for our traditional trading partners in Canada, Japan, Latin America and elsewhere - to a market nearly as large as our own, whose negotiators can speak with one voice but whose internal differences make it impossible for them to negotiate item by item."

The resulting 1962 Trade Expansion Act triggered a change in the way MTNs were run. From the Kennedy Round onwards, the tariff cutting was, broadly speaking, across the board for industrial tariffs. This institutional change had a massive impact on the alignment of political economy forces inside each of the major trading nations. Instead of having to fight for item-by-item-partner-by-partner improvements in market access, exporters in all participating nations could anticipate a massive increase in market access, if only they could convince their own governments to cut tariffs across the board. This launched the juggernaut dynamo on the thirty year path that crushed all tariffs in its way. The Kennedy, Tokyo and Uruguay Rounds each iteratively lowered industrial tariffs by about a third, with each cut reshaping the relative political economy power of pro-liberalisation and anti-liberalisation forces in all nations that participated on the basis of reciprocity.

\section{The 1960s burst of regionalism and multilateralism}

Domino effects were also in full swing during the 1960s. By 1968 the EEC had removed all tariffs on intra EEC trade and EFTA had removed all tariffs on intra-EFTA industrial trade; regionalism had fully liberalised the large fraction of world trade that took place inside these two blocs. The 1965 Canada-US Auto Pact, and the 1965 New Zealand Australia Free Trade Agreement brought tariffs to zero on a much smaller slice of world trade but reflected the eagerness of all the major traders to engage in regional tariff cutting in tandem with the multilateral tariff cutting in the Kennedy Round. The list of areas where regional liberalisation worked well lines up fairly well with the list of sectors liberalised multilaterally. The Kennedy Round was successful in liberalising industrial trade, especially in sectors dominated by two-way trade in similar products, but not agriculture. The same can be said of European integration. EFTA explicitly left agriculture out of the deal and the EU boosted protectionism in agriculture with its 1962 Common Agricultural Policy. In addition to regionalism and multilateralism, the mid-1960s saw the same set of nations engaging in some unilateral tariff liberalisation. Developed nations unilaterally cut tariffs on some imports from developing nations in 1965 and 1966 (WTO 1999) even before the formal launch of the Generalised System of Preferences (GSP) in 1974. Developing nations, by contrast, resisted tariff-cuts multilaterally, regionally and unilaterally. The 1960s saw a rash of South-South FTAs but none of these managed to alter trade flows significantly, presumably since they were not implemented (De Torre and Kelly 1992).

On the face of it, the 1960s show no sign of unilateralism, regionalism and multilateralism as being substitutes. The prima facia evidence is that they were complements.

\section{3, European Dominos phase II}

\footnotetext{
${ }^{22}$ On the EEC-GATT link see also Kaplan (1996), Destler (2005), Kenen (1989), and Preeg (1970).
} 
Britain and her companions' EEC applications were vetoed by French President Charles de Gaulle in 1963. He retired, the applications were reactivated and after many delays membership was granted in 1973. The enlargement triggered a second domino effect. EFTA industries pushed their governments to sign FTAs with the enlarged EEC. These took effect when the UK and company joined the EEC. Without the domino logic, it might seem strange that these EFTAns - who had found tariffs against EEC goods to be politically optimal for decades - suddenly found it politically optimal to lower tariffs bilaterally to zero. The losers-lobby-harder effect may have played a role here since without the FTAs, the UK would have had to raise tariffs against its former EFTA bloc members (the EEC is a customs union). The upshot of all this was that by 1973, Western Europe was a virtual free trade 'lake' for industrial goods created by the concatenation of the EEC, EFTA and the EFTA-EEC FTAs. See Figure 8.

This deepening and broadening of the West European free trade bloc threatened other major traders in the world. As in the early 1960s, the US, Japan, and Canada found themselves faced with a fresh expansion of trade diversion in the early 1970 s.
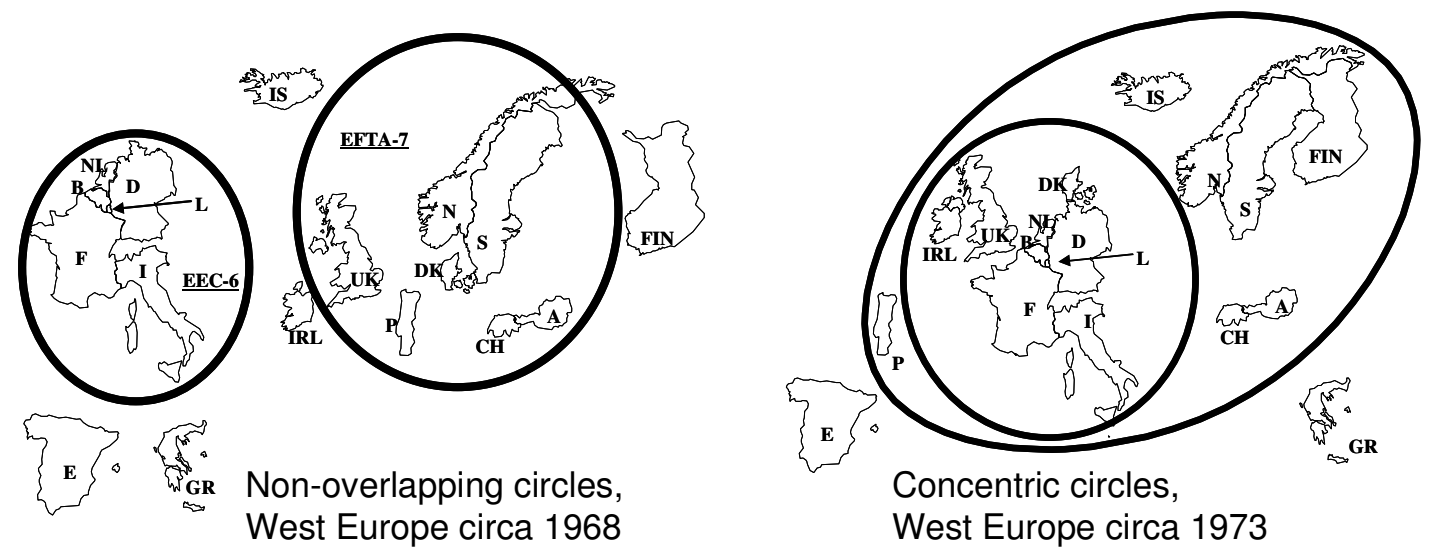

Figure 8: European Domino effect phase II.

Source: Baldwin (1994) figures 1.1, 1.2; www.hei.unige.ch/baldwin/

\section{3-1979 The juggernaut rolls forward: Tokyo Round, Juggernaut cycle 3}

The Kennedy Round tariff cuts, which reduced industrial tariffs by about a third, were phased in over eight years. This downsized import-competing industries and upsized export industries in all of the major trading nations and this political economy re-alignment prepared the stage for another round of cuts. As in the case of the Kennedy Round, the impending expansion of trade discrimination in Europe also played a role in creating a consensus for a new MTN (Bergsten 1998). Major trading nations again agreed to cut tariffs by about a third. The juggernaut rolled forward with the phase-in of these cuts. The Tokyo Round also implemented the 'Enabling Clause' that made official the asymmetric treatment of developing nations. In particular, it formalised the practice of exempting poor nations from the reciprocity principle in MTNs. It also disabled most of the GATT's discipline for the developing nations, so perhaps it should have been called the Disabling Clause. As in the 1960s, regionalism, unilateralism and multilateralism in the 1970s appeared to be complements. ${ }^{23}$ As shown in Figure 7, the Tokyo Round cuts, which started in 1979, did little to lower US average applied tariff rates; the focus of the Tokyo Round was on non-tariff barriers.

Two oil shocks (1973 and 1979) together with bungled monetary policy resulted in stagflation in the major trading nations. This economic climate of rising unemployment and double-digit inflation dampened enthusiasm for unilateral, regional, and multilateral liberalisation. Europe slipped into Euro-pessimism and the US slipped into what

\footnotetext{
${ }^{23}$ The multilateralism and unilateralism stemmed from the Tokyo Round, which cut MFN tariffs and pushed rich nations to preferentially and unilaterally reduce tariffs on poor nations' exports. Europe regionalism has been discussed. In the US, Section 612 of the Trade Act of 1974 authorised the President to agree an FTA with Canada; the 1979 Trade Act (section 1104) required the President to study FTAs with Canada and Mexico and the resulting report to Congress recommended that further regionalism (beyond the Auto Pact) be explored.
} 
was known as 'aggressive unilateralism' which included imposing a $10 \%$ import surcharge in reaction to the demise of the dollar-based Bretton Woods fixed exchange rate system.

\section{6 juggernaut cycle 4, European dominos phase III}

As stagflation was defeated with the 1981 and 1983 recessions, growth was restored to the major trading economies and the trade liberalisation dynamo slipped back into gear. After the usual squabbling among major trading nations over the agenda, a new MTN was launched in Uruguay in 1986. As Figure 9 shows, the Uruguay Round brought US and EU MFN tariffs down a notch from roughly $6 \%$ to roughly $4 \%$ where they are today.

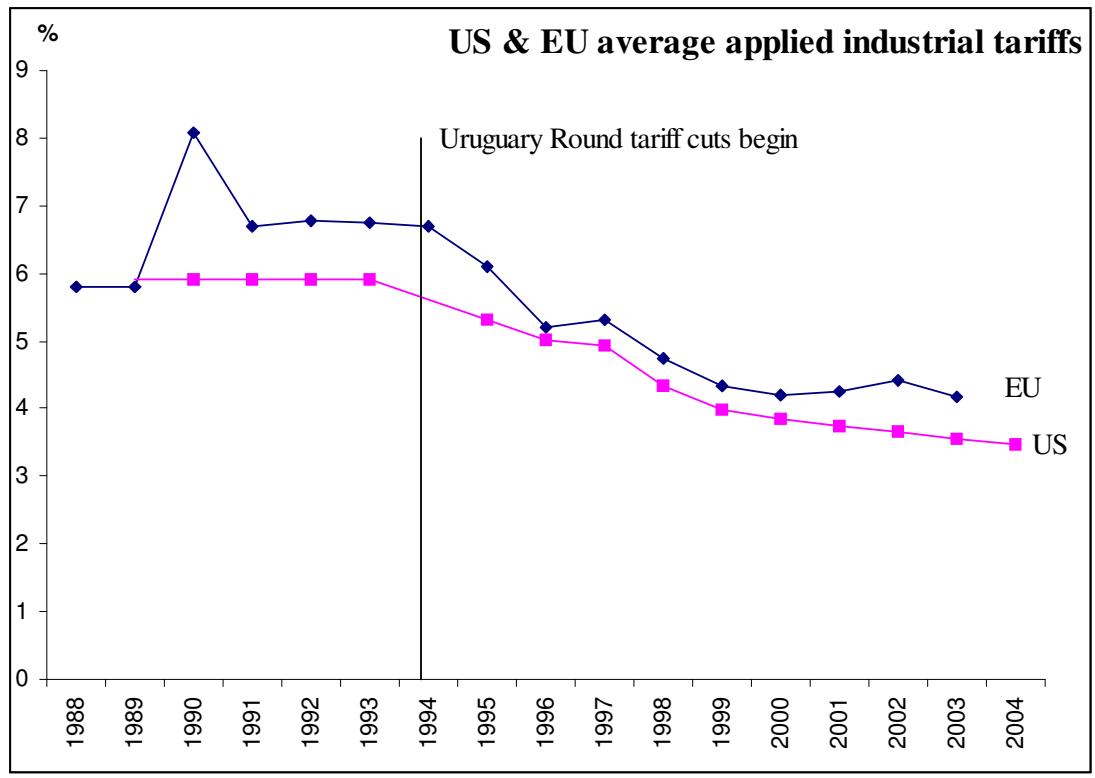

Figure 9: US \& EU MFN industrial tariffs 1988 - 2004.

Note: Simple average tariff on non-agricultural and non-fuel products dutiable imports from world. Source: Source: UNCTAD, TRAINS online database.

As in the 1960s and in the 1970s, regional trade liberalisation proceeded in parallel, partly due to domino effects but partly due to the fact that earlier liberalisation had re-aligned political economy forces in all major trading nations and this made all types of liberalisation politically optimal. ${ }^{24}$ The EEC developed, signed and ratified the Single European Act (SEA) in record time with the signature coming in 1986. The SEA resulted in a storm of liberalising Directives and a substantial deepening of economic integration. As in the 1960s, this triggered a domino effect. The excluded Western European sought to redress the discrimination via the European Economic Area (EEA) agreement, the aim of which was to extend the Single Market to EFTA (leaving agriculture aside). The EEA talks started in the mid-1980s, finishing only in 1993 due to a long string of mistakes and delays.

North American regionalism, which had not progressed since the 1965 Auto Pact, was also reignited. Canada had long resisted an FTA with the US (Canadian industry feared it would be overwhelmed by US industrial might), but in 1986 it proposed the Canada-US FTA (CUSFTA) and President Reagan accepted. Despite the success of the 1965 Auto Pact and the low initial level of US and Canadian tariffs, the talks proved difficult; CUSFTA entered into force in January 1989. Australia and New Zealand also decided to deepen their regionalism with the 1983 Closer Economic Relationship (ANZCER).

These three major regional liberalisation initiatives sought to go beyond mere tariff cutting. The juggernaut would explain this outreach to 'behind the border measures' on the basis of the political economy interests of exporters. Forming a winning coalition for liberalisation required governments to get their powerful export sectors really interested in pushing through the politically painful opening of import-competing sectors. Since industrial tariffs were already so low on major trade flows, the governments had to offer exporters more 'meat' and this took the form of better market access in services, the lowering of technical barriers to trade and heightened investment

${ }^{24}$ Some scholars argue that European regionalism in the 1970s prompted the Tokyo Round and the SEA prompted the Uruguay Round, e.g. Bergsten (1989). 
assurances. ${ }^{25}$ Since the political calculus for regional and multilateral liberalisation is broadly similar, it is not a coincidence that many of these deeper-than-tariff issues were also taken up in the Uruguay Round and forced on developing nations via the novel Single Undertaking approach. The new issues and the Single Undertaking were what was needed to get rich-nation exporters behind the package.

Plainly the 1980s showed no sign of unilateralism, regionalism and multilateralism being substitutes. 1986 saw i) the Uruguay Round launched, ii) a major step in European regional integration (the SEA), iii) a major step in North American integration (CUSFTA talks). The juggernaut approach explains this by noting the reshaping of the political economic landscape induced by trade liberalisation in the 1970s would have lower resistance from importcompeting firms to MTNs and RTAs while the expansion of export sectors would have raised political support for both. Moreover, European and North American regional integration, the SEA and CUSFTA, would bolster transAtlantic discrimination and this heightened the attractiveness of an MTN to both parties.

\section{1, American dominos phase I}

CUSFTA did not trigger a domino effect due to Mexico's traditional resistance to free trade in general and with the US in particular. The first domino effect in North America was triggered when Mexico changed tack and asked the US for an FTA. Mexico, which had hereto found it politically optimal to maintain high tariffs against US exports, changed its mind after it was rocked by a series of debt crises and severe recessions in the 1980s. From the juggernaut perspective, the recessions were pro-trade in that they eliminated many of the small firms that had lived on protection alone. Starting in 1988, the pro-market Mexican President Carlos Salinas cut tariffs unilaterally, joined the GATT, and signed several bilateral trade accords with the US and Canada, culminating in the Mexico-US FTA (MUSFTA). This triggered a massive domino effect in the Western Hemisphere. Canada asked to trilateralise the US-Mexico bilateral and the North American Free Trade Area (NAFTA) was born. The year was 1994.

The MUSFTA triggered domino reactions by re-arranging political economy forces throughout the Americas (Serra et al. 1997). Nations that had previously found it politically optimal to avoid FTAs with the US, now eagerly sought them. The low level of US tariffs did nothing to lessen the attractiveness of bilaterals. As explained above, lower overall trade barriers made industry more footloose, not less (home market magnification effect) so even small margins of preference could result in important investment diversion. The usual domino theory reactions were observed as nations sought FTAs to redress trade diversion and seize the mercantile benefits of trade creation. Chile, Brazil, Argentina, Uruguay and Paraguay all formally or informally approached the US with requests for FTAs. Protectionists in Congress were stirring for a fight (here the supply side of PTA starts to bite), so the Bush administration decided to privilege NAFTA and delay the others. It offered the Enterprise for the Americas Initiative instead in June 1990. This was a process intended to lead to FTAs (CEA 1991 Chapter 7), but the process started with unilateral liberalisation by the demandeurs in Latin America in the form of Framework Agreements; 26 countries in the Western Hemisphere signed Framework agreements in 1991 - the year US-Mexico bilateral talks started.

Since the most direct means of redressing trade diversion was blocked by the US Congress, many Latin Americans reacted in the same way the UK did in 1960 - they formed blocs among the excluded nations. The most important was Mercosur (March 1991). The idea started as a bilateral between Brazil and Argentina, but quickly created a domino effect of its own when the impending discrimination realigned pro- and anti-trade political forces in Paraguay and Uruguay such that they found it politically optimal to liberalise trade flows that they had previously found politically optimal to protect. The other Southern Cone country, Chile, who headed the queue for a US bilateral, resisted Mercosur membership initially. However, from 1990 to 1995 trade within Mercosur grew at 27\% annually while its external trade expanded at only 7.5\% (Yeats 1997). Chile joined as an associate member in October 1996. More dominos fell when Bolivia, Colombia, Ecuador, Peru and Venezuela became associate members.

Just as this tangle of FTAs was emerging in the Western Hemisphere, completely unrelated events triggered another tangle in Europe.

\footnotetext{
${ }^{25}$ Alan Winters pointed out that bringing service to the negotiating table added new players, not new benefits to old ones, or to put it differently, up till the 1980 s, service exporters, like industrial exporters pre-1934, we bystanders in the MTNs. The Uruguay Round and Single Market agendas changed this.
} 


\section{USSR falls: European spaghetti bowl emerges}

The division of Europe - which had been quite literally cemented in 1961 by the Berlin Wall - began to crumble as the East-West gap in living standards grew large. In the 1980s, the failings of Soviet economics forced some promarket reforms (perestroika) and greater openness (glasnost). Pro-democracy forces in Central Europe, which had hereto been flattened by Soviet military force, found little resistance in the late 1980s. The 'Solidarity' movement in Poland won free parliamentary elections; the result was a chain reaction of events. By 1991, the Eastern bloc disappeared and the USSR itself broke up into independent republics. The EU was quick to support the new democracies with aid. It also signed bilateral trade deals with a dozen Central and East European Countries (CEECs) some of which signed trade deals among themselves and this triggered a minor domino effect. To avoid the impending trade discrimination, the EFTAns signed FTAs with all 12 CEECs. This created a 'hub and spoke' bilateralism around the EU (Baldwin 1994 Chapter 5).

The liberalisation of trade between high-wage West Europe and the low-wage East Europe posed a threat to several Mediterranean nations who viewed the CEECs as competitors for EU investment and markets. This, together with the disappearance of the East-West conflict and the general adoption of pro-market policies, led several of the Mediterranean nations most dependent upon the EU's market to seek bilateral FTAs (taking a step up from the unilateral preferences the EU was already granting them under GSP). The EU's reaction in 1995 - the Barcelona Process - promised another dozen hub-and-spoke bilateral FTAs. Turkey led the Meds by joined the EU customs union in 1995, the same year that the EU signed bilaterals (called Euro-Meds) with Tunisia and Israel. Others followed rapidly: Morocco (1996), Jordan (1997), PLO (1997), Egypt (2001), Algeria (2002), Lebanon (2002) and Syria (2004). This proliferation of FTAs was multiplied by deals among some of the 'Meds' themselves, e.g. Arab Maghreb Union (Morocco, Algeria, Tunisia, Mauritania and Libya) and Agadir Agreement (Morocco, Tunisia, Egypt and Jordan). The Barcelona Process has the overarching goal of establishing a Euro-Med free trade zone by 2010.

For two decades trade had been quite harmonious in the virtual West European trade zone comprising the EU and EFTA. The flurry of EU and EFTA bilaterals with the 'new' neighbours changed all this. Although the EU's hegemonic position meant the bilaterals were not as disparate as they might have been, each involved only bilateral cumulation so the rules of origin began to matter. To tame the European 'Spaghetti Bowl', the EU pushed through the Pan-European Cumulation System (PECS) in 1997. The EU15, the EFTA4 (Iceland, Liechtenstein, Norway and Switzerland), and ten of the then applicant-nations in Central Europe decided to amend their various FTAs by substituting a common set of rules of origin for those they originally contained. Value could thus be cumulated between different European countries without prejudicing the duty-free status of end products. PECS was extended to Turkey in 1999, and the EU promised in 2003 to extend it to the Euro-Med bilaterals. PECS members account for about $40 \%$ of world trade.

\section{Dominos trigger juggernaut effects: 'fuzzy and leaky trade blocs'}

While the US and EU emerged as hubs in their networks of hub-and-spoke FTAs, the spokes started to react in the 1990s and new century. In both Europe and North America, the spoke's found little domestic opposition to further tariff cutting since their FTAs with their dominant trade partner (US or EU) had reshaped their economic landscapes in a way that strengthened pro-trade forces and weakened anti-trade forces. Mexico provides the most striking example of this new interaction between domino and juggernaut effects.

NAFTA meant that Mexico had zero tariffs on most of its imports. Because the US maintained low MFN tariffs, bilateral free trade with the US produced domestic prices in Mexico that resembled those that would be observed under free trade with the world (with a few exceptions like sugar and clothing). In short, NAFTA launched a juggernaut effect that crushed in 10 years the sort of protectionist forces that took the GATT four decades to crush in the US and Canada. This realigned Mexican political economy forces, eliminating firms that might have objected to liberalisation outside of NAFTA and creating some that would gain. Mexico could have gone for unilateral free trade or offered steep tariff cuts in the Doha Round. The 'Disabling Clause,' however, meant that Mexico felt no obligation to play reciprocally in the WTO and Article 24 meant that there was no reason to give up its MFN tariffs for free. Mexico decided to 'sell' its market access bilaterally. The result has been impressive. While almost $90 \%$ of Mexico's exports go to NAFTA, Mexico signed FTAs with the EU and Japan in additional to FTAs with another 40 
or so nations; the main ones being with Chile, Bolivia, Costa Rica, Colombia, Venezuela, Nicaragua, Israel, EFTA, Guatemala, Honduras, and El Salvador. Trade with most of these nations grew rapidly, and this was seen as validation of Mexico's decision to go bilaterally instead of unilaterally or multilaterally.

Chile's political economy forces were similarly re-arrayed by its FTAs and unilateral liberalisation and this pushed its government to adopt Mexico's "promiscuous bilateralism." Chile's list of FTAs includes the plums of NAFTA, EU and Japan as well as a list of bilaterals with small nations is almost as impressive as Mexico's.

In a sense, Mexico and Chile were merely mimicking Singapore's strategy. Singapore, which has long embraced unilateral free trade, has literally nothing to lose from a political economy standpoint from one more FTA and its exporters may potentially gain some preferences. (The optimal trade policy for a small nation is not unilateral free trade, it is unilateral free trade and every FTA it can get its hands on.) So far Singapore has free trade deals with the US, Japan, Korea, EFTA, Australia, New Zealand, India, Chile and China; it is talking with the EU, Canada and a slew of West Hemisphere and Asian nations.

The remaining EFTAns - Switzerland, Norway, and Iceland (Liechtenstein is in a customs union with Switzerland) - had until recently been content to shadow the EU's FTAs in order to prevent discrimination for EFTA-based exporters. Starting in 2002, when the EFTAns signed bilaterals with Singapore, EFTA began to imitate Mexico's strategy of seeking trade deals independently of its dominant trade partner. For example, it is now the EU playing catch up after EFTA's deal with Korea; Switzerland even sought an FTA with the US although the effort failed. $^{26}$

This implication of the juggernaut effect - that small nations are now seeking global networks of FTAs - has made the three classic trade blocs - Europe, North America and East Asia - into what might be called fuzzy, leaky trade blocs; 'fuzzy' since the proliferation of bilaterals by the spokes make it difficult to determine the boundary of the Big-3 blocs, and 'leaky' because some of the spokes have FTAs with more than one of the Big-3 trade blocs. Mexico, Chile and Singapore, for example, have deals with all three blocs; Jordan has an FTA with the US and EU.

\section{US tariff cutting back on track}

After the post-NAFTA, post-Uruguay Round hiatus, the new century has seen the US return to the three-track tariff-cutting approach it pursued in the 1960s, 1980s and 1990s, namely unilateral, bilateral and multilateral. On the unilateral front a notably innovation was the African Growth and Opportunity Act of 2000. On the multilateral front, the US fully engaged in the Doha round tariff cutting process. ${ }^{27}$ It was the bilateral front however that has seen the most movement. The US has signed or is negotiating deals with Singapore, Chile, Jordan, Australia, Morocco, El Salvador, Nicaragua, Honduras, Bahrain, Guatemala, the Dominican Republic, Costa Rica, Oman, Peru and Colombia. Tentative talks have begun with Korea and several other East Asian nations. As in Europe in the mid1990s, the tangle of bilaterals is creating a Western Hemispheric spaghetti bowl.

\subsubsection{Stock taking and accounting for the stylised facts}

The Juggernaut-domino duo can directly explain stylized facts 1, 2, 3 and 4.

Fact 1 is easy. Tariffs were high to start with since they were, to a large extent, set unilaterally.

Fact 2 is due to the fact that developing nations did not participated in GATT/WTO Rounds on the basis of reciprocity. Until the 1970s, the GATT was a rich-man's club. Most poor nations were colonies or newly independent states; few wanted to join. When GATT membership began to appeal to developing nations, it became clear that something would have to change given the GATT's consensus decision-making rule. The solution was the 1979 "Enabling Clause." This solved the problem of consensus with an economically diverse membership in a curious manner. The GATT rules and decision-making procedures were designed for and by a handful of industrialized nations in the mid-1940s. The hallmark of the GATT was inflexible but minimalist rules (MFN, reciprocity, etc.) and decision-making by consensus so that no member would be forced to accept deeper commitments against their will. This posed two types of problems. The principle of consensus (unanimity) meant that the newcomers could jam up all future progress with their shear numbers, and the vast economic differences

\footnotetext{
${ }^{26}$ See Hufbauer and Baldwin (2006) for an analysis; talks broke down when US made it clear that its FTA template (applied to all FTAs negotiated since 2000) was not negotiable in its main outlines, and Switzerland decided it could not accept the main outlines, especially the commitment to eventual free trade in agriculture. ${ }^{27}$ This was written before the Doha Round went into hibernation in July 2006.
} 
between incumbents and newcomers implied that they were likely to have very different opinions as to where the GATT should go. The Enabling Clause fudged rather than solved the problem; it absolved developing nations from GATT disciplines and this turned GATT membership for poor members into a don't-obey-don't-object proposition. The GATT continued to be run by the Quad despite the numerical dominance of developing nations. What this meant was that the MTN's were like a political-economy Christmas for poor nations; they slept soundly as Father and Mother Christmas argued over what market-access presents to put under the tree. Not surprisingly, the gifts did not always reflect what the poor nations really wanted. By contrast, rich nations got the market access they paid for. ${ }^{28}$ The juggernaut hinges on reciprocity. MTN Rounds did not convert developing country exporters from bystanders into free traders. Little wonder, then, that they decided to stay with the initial level of their tariffs, which were after all politically optimal to begin with. Observe that the Single Undertaking undid this don't-obey-don'tobject deal. All this was by way of accounting for Fact 2.

As for Fact 3, gradualism, the approach relies on the slow adjustment of industry structures. Reciprocity triggers slow changes in the political economy landscape which slowly alter the politically optimal tariff.

Fact 4 - that the juggernaut failed to crush tariffs in sensitive sectors such as clothing and food - requires another modification of the basic juggernaut framework. Until the 1990s, GATT Rounds focused on manufactured goods, so it is no surprise that food was not liberalised. More specifically, the import competitors in the EU, US and Japan were so strong that they managed to take food tariffs off the bargaining table. ${ }^{29}$ As a result, no one inside the EU, US or Japan gained from lobbying against food tariffs. Food tariffs were shielded from the juggernaut and thus remained at their uncoordinated levels. This changed in the Uruguay Round and the juggernaut's power is now in the process of crushing agricultural protection.

Fact 5 is explained by the intra-sectoral special interest political economy discussed above. The juggernaut in these industries arrayed the pro-trade political economy interests of large exporting firms against the anti-trade interests of small firms in the same industry and same country.

Fact 6 - the fact that multilateral and regional liberalisation proceeded in tandem since 1947 - has been abundantly explained in the preceding historical narrative. There are some important differences between unilateralism and regionalism (trade diversion and creation) and between unilateralism and multilateralism on the other (reciprocity). The common dynamo, however, relies on the way that liberalisation rearranges the political economic landscape in each nation participating on the basis of reciprocity. The altered landscape tends to foster all forms of liberalisation regardless of what causes the initial market opening. As for developing nations, they did not engaged in reciprocal trade liberalisation and so never found it politically optimal to lower the tariffs that they had previously found politically optimal to impose. This has changed recently as some developing nations are engaging in bilateral reciprocal liberalisation and many have engaged in unilateral tariff cutting (more on this below).

The historical narrative so far has focused on the major trading nations - the US, Canada, the Europeans and Japan - since these nations accounted for the bulk of world trade and almost all of the world's tariff-cutting. The biggest changes in the topography of world trade liberalisation in the past decades, however, have been in Asia. Since the late 1980s, East Asian regional trade has flourished. While an East Asian domino effect has been in operation since 2000, there is still very little preferential trade in East Asia. The major tariff cutting in the region was due to unilateral initiatives rather than RTAs or MTNs. This brings us to stylised fact number seven.

\subsubsection{Asian race-to-bottom unilateralism and Asian dominos phase I}

Until the 1980s, tariff cutting in Asia was limited to Japan's MFN tariff liberalization in the GATT and its unilateral extension of preferences to other Asian nations. Neither regionalism nor unilateralism had gained a foothold. There are many reasons for this. For example, there was only one big economy in the region (Japan) and although this normally would have created a hub-and-spoke outcome as it did in Europe and North America, the natural East Asian 'spokes' explicitly resisted the draw of the Japanese economy, fearing - just as Canada and

\footnotetext{
${ }^{28}$ There were also policy rationales for the Enabling Clause. In the 1970s economists and politicians believed that import substitution was critical to industrialisation, so market-access reciprocity would hinder poor members' development.

${ }^{29}$ The fundamental reason may have to do with agriculture's specific technology. Protection can only create permanent rents if entry is restricted permanently. It can create quasi-rents in industrial sector, but this only serves to protect sunk costs. Since sunk costs in industrial sectors eventually erode, while the land-based entry restrictions in agriculture do not, one could expect farm landowners to take a much longer perspective than the owners of industrial sunk assets. This suggests that farm landowners would be willing to engage in much more extensive and expensive lobbying to keep agriculture off the MTN bargaining table.
} 
Mexico did until the 1980s - that their giant neighbour's industry would overpower their manufacturing sectors. As part of this, most East Asian nations maintained high barriers against industrial imports in general and against Japanese exports in particular. This high-tariff political equilibrium, however, was shocked by changes inside Japan. The result was rapid and impressive unilateral tariff cutting in East Asia.

\section{Race-to-the-bottom unilateralism: establishing Factory Asia ${ }^{30}$}

In 2006, East Asia can be thought of as a highly integrated 'factory' in which formerly national production processes have been 'unbundled' and dispersed to the lowest cost location in East Asia. ${ }^{31}$ For some labour-intensive components, the low-cost nation is Thailand or China. For engineering-intensive components the low-cost nation is Japan or Korea. Surprising as it may seem, all this regional trade creation happened outside the aegis of regional trade agreements. The commercially important arrangements - the ASEAN-China FTA and ASEAN-Korea FTA are supposed to be phased in by 2010 but have not yet done much tariff cutting. The only arrangement that has been implemented, the ASEAN Free Trade Area (AFTA), is not actually used - its utilisation rates are below 10\% (JETRO 2003).

Factory Asia got established via unilateral liberalisation of tariffs on the parts-and-components trade that makes up the bulk of intra-East Asian trade. The tariff cutting was non-discriminatory but the effect was regional given the nature of the goods and the network of Korean, Japanese and Taiwanese multinationals. Factory Asia's construction began in the mid-1980s when most East Asians followed 'dual track' industrialisation strategies that blocked imports while promoting exports. The erosion of Japan's comparative advantage in manufacturing and the global trend towards 'unbundling' of manufacture processes led Japanese firms to 'unbundle' their manufacturing process and off-shore labour-intensive stages of production to nearby East Asian nations. This 'hollowing out' of the Japanese economy started the development of "Factory Asia" and the hollowing out of Taiwan, Korea, Singapore and Hong Kong extended it. As in the rest of the world, the deep cause of unbundling was the falling costs of moving ideas, goods and people, but the result was more extreme in East Asia due to the extreme factor price differences in a geographically compact area. Factory Asia's next big fillip came from China's decision to join the world economy. This accelerated the erosion of the industrial comparative advantage in high-income East Asian nations while simultaneously boosting the attractiveness of off-shoring.

How did the emergence of Factory Asia foster unilateral liberalisation? The off-shoring strategies of Japanese and Korean firms fit in nicely with the export-track of the dual-track development strategies being pursued by China and the ASEANs. To attract such investment, the ASEANs unilaterally reduced their tariffs in what may be viewed as a 'race to the bottom'. While it is hard to find direct evidence that the unilateral tariff cutting in this phase was caused by competition for Factory Asia investment, anecdotal evidence is abundant, see for example Kuchiki (2003). As the complexity of Factory Asia grew and timeliness in production became a key competitive factor, the time and cost of negotiating duty drawbacks and special deals on a product by product, firm by firm basis began to tell. Nations found it useful to switch from special deals to non-discriminatory lowering the applied MFN tariff. The impressive results are shown in Table 6. Some East Asians have always had low tariffs and some still have high tariffs (India and Vietnam), but the major East Asian developing nations cut tariffs unilaterally in an impressive way in the last 15 years, especially in the 1990 s.

Table 6: Unilateral tariff cutting in East Asia, 1991 to 2003 (average applied tariffs \%).

\begin{tabular}{lllllllll}
\hline \hline & $\mathbf{1 9 8 9}$ & $\mathbf{1 9 9 2}$ & $\mathbf{1 9 9 5}$ & $\mathbf{1 9 9 9}$ & $\mathbf{2 0 0 0}$ & $\mathbf{2 0 0 1}$ & $\mathbf{2 0 0 2}$ & $\mathbf{2 0 0 3}$ \\
\hline India & & 59 & & 34 & & 31 & & 28 \\
Vietnam & & & 14 & 15 & & 15 & 15 & 16 \\
Thailand & 40 & 40 & 20 & & 16 & 15 & 14 \\
China & & 42 & 35 & 16 & 16 & 15 & 9 & 11 \\
Malaysia & 14 & 14 & & & & 9 & 9 & 8 \\
Korea & 14 & 11 & 8 & 8 & & & 8 & 8
\end{tabular}

\footnotetext{
${ }^{30}$ See Whalley and Banda (2005), Lamy et al (2006), Lijun, (2003), ADB (2006), or Baldwin (2006a) for a more extensive, data-based account of the evolution of East Asian regionalism from 1985 to present.

${ }^{31}$ On Factory Asia see Ando (2004), Ando and Kimura (2004, 2005), Kimura and Ando (2003, 2005), Ng and Yeats (2003), and Fukao, Ishito and Ito (2003). Many authors call this 'fragmentation' but that term suggests the pre-fragmentation situation was the natural state that got broken up by globalisation. Another view is that the initial state was an unnatural bundling of productive factors that was only made economic by high trade and communications costs (Baldwin 2006, b).
} 


\begin{tabular}{|c|c|c|c|c|c|c|c|c|}
\hline Indonesia & 23 & & 16 & 11 & 9 & 7 & 7 & 7 \\
\hline Taiwan & 10 & 6 & & 6 & 6 & 6 & 6 & 5 \\
\hline Philippines & 28 & 19 & 19 & 9 & 7 & 7 & 5 & 4 \\
\hline Singapore & 0 & & 0 & & & 0 & 0 & 0 \\
\hline
\end{tabular}

\section{The limited role of regionalism}

Regionalism played almost no role in fostering East Asian trade in the 1985-2000 period. In particular, although AFTA was set up in 1992 it did little to foster liberalisation. Intra-AFTA trade is dominated by trade in parts and components. HS Chapters 84 and 85 account for $50 \%$ of the intra-AFTA trade and fuels and lubricants for another $10 \%$. On these items, the ASEANs have cut their applied rates to zero or very low levels, so there is almost no margin of preference that would justify the cost of complying with rules of origin. This lack of regional preference can be seen in the second and third rows of Table 7. The final bit of evidence is the extremely low utilisation rate in AFTA. In the late 1990s, the overall utilization rate was under 3\%. By 2002, the rate was $11 \%$ for Thailand and $4 \%$ for Malaysia (JETRO 2003). For comparison, utilization rates below 50\% are considered very low in European preferential agreements (Augier Gasiorek and Lai Tong 2005, Candau, Fontagne and Jean 2004).

Table 7: Intra-East Asian preference margins vis-à-vis EU and North America

\begin{tabular}{|c|c|c|c|}
\hline \multirow[b]{2}{*}{ Sector: } & \multicolumn{3}{|c|}{ Exporter to East Asia } \\
\hline & East Asia & $\begin{array}{c}\text { North } \\
\text { America }\end{array}$ & EU \\
\hline Mining products (HS25-27) & 1.7 & 2.6 & 1.7 \\
\hline General machinery (HS 84) & 1.5 & 1.9 & 2.5 \\
\hline Electrical machinery (HS 85) & 1.4 & 1.5 & 2.2 \\
\hline Others & 1.4 & 1.7 & 2.6 \\
\hline Wood and paper & 1.4 & 1.3 & 1.5 \\
\hline Precision apparatus & 1.2 & 1.3 & 2 \\
\hline Agriculture & 41 & 29.7 & 30.9 \\
\hline Light industry & 26.8 & 8.3 & 12.8 \\
\hline Food and beverages & 21.8 & 26.4 & 25.8 \\
\hline Textiles and clothing & 7.3 & 7.6 & 7.8 \\
\hline Transportation machinery & 4.6 & 2.8 & 8.6 \\
\hline Pottery products & 2.9 & 3.6 & 4.4 \\
\hline Chemicals & 2.4 & 3 & 2.7 \\
\hline Basic metals & 1.8 & 2.6 & 2.3 \\
\hline All products & 7.4 & 5.5 & 7.2 \\
\hline
\end{tabular}

Note: Tariff data for 2002; see the source for aggregation schemes.

Source: Author's reorganisation of data drawn from Freudenberg and Paulmier (2005), Table 3.

\section{China sparks East Asian domino effect phase I}

While race-to-the-bottom unilateralism was the only liberalising force that worked well until the year 2000, East Asia has since experienced a massive domino effect with dozens of new RTAs being announced, negotiated and signed. The 1997 Financial Crisis is sometimes held accountable for this, but the domino theory provides an alternative framework in which one can understand the facts. Under the domino theory, the key event was China's WTO membership. ${ }^{32}$

China's WTO membership would provide an external lock-in of Chinese unilateral economic reforms, and this, many believed, would magnify China's attractiveness as a location for Factory Asia jobs and investment. To assuage ASEAN fears of new Chinese competition, Chinese leader Zhu Rongji suggested an FTA between China and ASEAN at the November 2000 China-ASEAN Summit. The idea, which came as a surprise, led to the 2003 ASEAN-China Free Trade Agreement (ACFTA), which is scheduled to eliminate tariffs on almost all bilateral trade between China and the ASEANs by the year 2010. This triggered a domino effect among the ASEANs themselves since they moved up the deadline for AFTA to match the ACFTA's date of 2010.

The domino effect quickly spread. Japan and Korea realised that preferential liberalisation between two of their major markets - China and ASEAN - would create discrimination against their goods. It is true that no one knew what ACFTA might become, but Japan and Korea simply had to have a plan in case major tariff discrimination did

\footnotetext{
${ }^{32}$ See Baldwin $(2002,2006$ a) for a much more detailed accounts of the East Asian domino effect.
} 
arise. In this way, China's surprise offer in November 2000 triggered an East Asian domino effect that continues to play itself out today. Since Japan and Korea could not join ACFTA, they adopted Britain's 1960 strategy of forming another trade bloc and signing bilaterals with the smaller/more-susceptible members of the new trade bloc. The result was the Japan-Korea FTA talks (which have stalled), the Japan-ASEAN bilaterals (which are well on track), the broad Japan-ASEAN FTA (which is progressing slowly), and the Korea-ASEAN FTA (which has worked with the exception of Thailand). Recently, trading powers outside East Asia have been drawn in. The ever lengthening list includes Australia, New Zealand, India and the US.

The result has been an East Asian 'noodle bowl' syndrome. Depending upon how one counts them, dozens if not hundreds of trade deals are under discussion, under negotiation, or already signed. The ASEAN-Korea FTA (AKFTA), ASEAN-China FTA (ACFTA) and ASEAN-Japan FTAs (AJFTA) should be thought of as separate deals since - given ASEAN's the rather unique way of negotiating FTAs - the tariff charged on a particular product can be different for each of the 30 bilaterals trade flows. Likewise, all the bilateral trade links inside AFTA should be listed as separate agreements given the disjointed nature of ASEAN. ASEAN's method of preferential liberalisation implies that the degree of market access faced by an exporter of any particular product based in any particular ASEAN nation varies according to the ASEAN destination market concerned. ${ }^{33}$

\subsection{Future history: Staging post 2010}

The section up to here has focused on relating a broad historical narrative of global post-war trade liberalisation organised around the logic of three political economy effects: dominos, juggernauts and RTB unilateralism. The narrative was intended to build confidence in the usefulness of the three political economy effects, and this, in turn, to build confidence in the predictions of what the world trade system might look like in 2010. The next task is to take stock of the global liberalisation to date and then to use political economy logic to project what the world may look like in 2010. The year 2010 is chosen since it is the deadline set for the harmonisation if Europe's bilaterals with its Mediterranean neighbours and, more importantly, the year by which full implementation of East Asia's RTAs should have taken place.

Table 8: World network of trade, 2004.

\begin{tabular}{|c|c|c|c|c|c|c|c|}
\hline & Europe & NAFTA & Asia & $\begin{array}{l}\text { Middle } \\
\text { East }\end{array}$ & Africa & $\begin{array}{l}\text { S. \& C. } \\
\text { America }\end{array}$ & World \\
\hline Europe & $33 \%$ & $7 \%$ & $8 \%$ & & $2 \%$ & & $45 \%$ \\
\hline NAFTA & & $8 \%$ & $9 \%$ & & & & $15 \%$ \\
\hline Asia & & & $13 \%$ & $3 \%$ & & & $27 \%$ \\
\hline Middle East & & & & & & & $4 \%$ \\
\hline Africa & & & & & & & $3 \%$ \\
\hline South and Central America & & & & & & & $3 \%$ \\
\hline World & $44 \%$ & $21 \%$ & $23 \%$ & $3 \%$ & $2 \%$ & $3 \%$ & $100 \%$ \\
\hline
\end{tabular}

Note: The inter-regional flows are summed over both directions, so there are no entries in the lower triangle of the matrix. All flows are taken as a $\%$ of world trade and numbers less than $2 \%$ are zeroed out for clarity's sake. CIS-Europe's bi-lateral trade is omitted; it accounts for $2.4 \%$ of world merchandise exports in 2004 (my thanks to Michael Finger for this).

Source is WTO (2005), Table A1.

The world trade pattern does not change very quickly, so in 2010 it is likely to resemble the 2004 pattern shown in Table 8 . The $33 \%$ of world trade that takes place inside of Europe is already tariff-free and almost surely will remain so. By 2010 the Euro-Med free trade area should be completed and PECS extended to it, but given the small economic size of the Meds this will do little to alter the $33 \%$ figure. The $8 \%$ of world trade that takes place within NAFTA is also basically duty free and almost sure to remain that way; many US, Mexican and Canadian extraNAFTA bilaterals will have been implemented, but again these cover small trade volumes by world standards. The big change will be in East Asia. If the promises that have been made in East Asia are kept, the 13\% of world trade inside that region will be basically tariff-free. This assertion requires some conjecture, however, since the three main flows in East Asia are among China, Japan and Korea and these are not slated for liberalisation. (See Table 9 for information on the size of intra-East Asian flows in comparison to other major world trade flows.)

\footnotetext{
${ }^{33}$ Basically preferences are only granted on products that are on neither partner's sensitive list, so market access is defined by the interaction of the two lists thus creating different market access for every one of the 45 bilateral flows among the 10 ASEANs.
} 
Table 9: Intra East Asian trade flows as \% or world trade, 2003.

\begin{tabular}{llllllll}
\hline \hline & ASEAN & $\begin{array}{l}\text { Greater } \\
\text { China }\end{array}$ & Korea & Japan & EU & US & ANZ \\
\hline ASEAN & $5 \%$ & $10 \%$ & $2 \%$ & $6 \%$ & $6 \%$ & $5 \%$ & $1 \%$ \\
US & $1 \%$ & $3 \%$ & $1 \%$ & $2 \%$ & $3 \%$ & & \\
Greater China & $1 \%$ & $3 \%$ & $1 \%$ & $2 \%$ & $1 \%$ & $1 \%$ & \\
EU & $1 \%$ & $2 \%$ & & $1 \%$ & & $2 \%$ & \\
Japan & $1 \%$ & $1 \%$ & & & $1 \%$ & $1 \%$ & \\
China & $1 \%$ & $1 \%$ & $1 \%$ & $1 \%$ & $1 \%$ & & \\
Canada & & & & & & $2 \%$ &
\end{tabular}

NB: Each ASEAN's export to column markets less than $1 \%$ of world trade

Notes: The trade flows (uni-directional) are as a \% of world trade ( $\$ 7.3$ trillion); numbers less than $1 \%$ are rounded to zero for clarity's sake. Source: IMF DOTS database.

The major RTAs that have been or soon will be signed are the agreements between AEASN and China (ACFTA), ASEAN and Korea (AKFTA), and bilateral FTAs between the big ASEANs (Malaysia, Thailand, Philippines, Indonesia) and Japan. There are indications that ACFTA is not on schedule and it would certainly not be unusual for south-south RTAs to be signed and not implemented. In the case at hand, there seems to be a fear among ASEANs that freer trade with their huge neighbour would to turn China into a 'growth pole' and them into 'growth sinks', to use some old economic geography terminology. The AKFTA has just been signed but it is already showing signs of strain since one of the ASEANs, Thailand, refused the deal based on Korea's decision to excluded rice.

The situation is quite different when it comes to Japan. The ACFTA, AKFTA and AFTA appear to be relatively undisciplined. For example the actual texts of the agreements have no clear surveillance, enforcement and adjudication provisions on many issues, especially non-implementation. Japan's bilateral FTA with Malaysia, by contrast, is an Article 24-consistent FTA with all the usual surveillance, enforcement and adjudication of a NorthNorth FTA. This, plus the enormous asymmetry of the partners suggests that this FTA will be implemented since the political economy forces in Japan, and especially Malaysia, will keep their governments to their promises. Given the usual domino effects, the Japan-Malaysia deal is likely to force the other major ASEANs, Thailand, the Philippines and Indonesia, to complete their on-going bilateral FTA talks with Japan.

If the Japanese bilateral FTAs with the major ASEANs are implemented, important discrimination will appear in East Asia for the first time. Following the predictions of the domino logic, political economy forces throughout the region will find it politically optimal to redress this discrimination. There are many ways to do this, some involving RTAs, others involved heightened RTB unilateralism. In either case, the likely outcome is that the main trade flows in East Asia will be substantially duty-free by 2010. This zero-tariff treatment, however, will be supported by a motley assortment of regional, unilateral and multilateral arrangements.

Here it is useful to once again recall the 'home market magnification effect'. Since trade barriers in many parts of East Asia are already so low (Japan's and Korea's due to GATT/WTO obligations; and ASEAN's and China's due to unilateralism) small advantages can have an outsized impact on the location of industry. Since the desire to avoid such delocation is often at the heart of East Asian governments' application of the domino logic - they have to redress actual or impending trade discrimination by signing FTAs to avoid seeing their industry 'vote with their feet' for free trade access - the magnification of the effect means that despite the low margins of preference, the domino logic continues to drive forward an exponential expansion in the number of FTAs and/or RTB unilateralism.

\section{Where will the tariff barriers be in 2010?}

Many developing nations in the Middle East, Africa and South and Central America will maintain tariffs on manufactured goods, but these flows have very little impact on world trade. Indeed, there are only two trade flows involving the Middle East, Africa and South and Central America that cross the 2\% threshold - the flow between Europe and Africa and the one between the Middle East and Asia (Table 8). Much of the former is in the process of being liberalised via Euro-Med agreements, GSP and other bilaterals, while the latter involves trade in fuels which is largely duty free in any case.

In short, almost all of the trade flows that are large enough to matter on the global scale will be quite close to duty free, although most of this duty-free status will be governed by RTAs and unilateralism rather than WTO bindings. 
There are two important proviso to this optimistic forecast. First, the Asian unilateral trade liberalisation that has done so much to build Factory Asia is largely undisciplined. Most of the FTAs were announced under the Disabling Clause and the unilateral tariff cuts have not been bound in the WTO. In short, East Asian regionalism resembles the interwar regionalism rather than the GATT-disciplined postwar regionalism in North America and Europe. There is very little in the way of institutions to ensure that bilateralism remains benign in East Asia. Finally, there is always the possibility of inter-bloc trade war, but so far the possibility seems remote since most of the nations concerned would have to violate their WTO obligations on tariff bindings to carry out such a war. While this could always happen, the solid political economy forces that pushed the juggernaut forward since 1947 are likely to restrain their governments from such folly. Moreover, the existence of 'free trade canals' linking the 'free trade lakes' within each of the Big-3 trade blocs will alter the political economy calculation of intra-bloc trade war. It is hard to maintain a siege when part of your wall encompasses the enemy's camp.

\subsubsection{The Big-3 as fuzzy, leaky trade blocs}

Given sufficient imagination, one could see the world in 2010 as three perfectly formed trade blocs - one in Europe, one in North America and one in East Asia. This would be wrong. Only one of the Big-3 is actually a bloc (the EU is a customs union). The other blocs are basically matrices of bilateral deals with minimal institutional integration. NAFTA is substantially ahead of Asia on the intuitional front, and it does have a leader, but NAFTA institutions are a very long way from allowing NAFTA to speak with one voice in the WTO or in the context of any breakdown of the WTO system. Asia has almost no institutional integration, zero political integration and no regional leader.

All three blocs have 'fuzzy' boundaries. Again the EU is the most cohesive (due to its PECS scheme and its extension to the Meds) but the EU's system of hub-and-spoke bilaterals is far from tidy. Some of the spokes, e.g. EFTA, Turkey and other Meds, have their own bilaterals, some of them with nations outside the Euro-Med area. This means that the geographical boundary of the European trade bloc is not a sharp line. When it comes to trade, Europe is a 'fuzzy set.'

NAFTA itself is basically a set of bilaterals that have been hegemonically harmonised by the US. For example, Chile did not join NAFTA; it signed NAFTA-like bilaterals with the three incumbents. The US has also signed a network of hub-and-spoke trade agreements with an astonishing diverse range of nations, and it has more in the pipeline. Although there is some coherence among these (since all of them had to match the US's template FTA which includes NAFTA-like rules of origin), disparate coverage and phase-in periods as well as bilateral cumulation make it difficult to precisely define the edge of the NAFTA-centric trade bloc. For example, Mexico and Canada have signed their own networks of bilaterals and these typically do not follow the US template, nor do they follow the geographical pattern of US bilaterals. In this sense, the frontier of the North American trade bloc is fuzzy.

The fuzzy trade bloc concept is clearest in Asia. In some ways India is, or soon will be, part of the East Asian trade bloc, but it is unlikely to be able to sign an FTA with the dominant economy in the region, Japan. Moreover, the three dominant economies in East Asia (Japan, China and Korea) are not linked by trade agreements. As of 2006, the prospects for any one of the three bilaterals necessary to complete the East Asia trade bloc (China-Korea, Korea-Japan, Japan-China) being in place by 2010 appears remote, but there is always the chance the domino effect will make it politically optimal to sign deals that it is now politically optimal to resist.

These trade blocs are leaky as well as fuzzy - leaky in the sense that each bloc's tariff wall against the other two blocs have several holes in the form of cross-bloc FTAs. These non-regional RTAs are one of the newest and most curious aspects of the juggernaut-domino effect. Regional and unilateral liberalisation has so altered the political economy geography inside some small nations, that FTAs have become a "why not?" proposition. The fact that the blocs are leaky probably changes things, at least when it comes to considering the prospects for trade war among the Big-3. For example, if the US and the EU went to trade war over trade in automobiles, the car industry job losses in the US would be amplified by delocation to Mexico; US-EU barriers would heighten the attractiveness of Mexico as a production platform and thus the value of the Mexico-EU bilateral. In other words, trade war among leaky trade blocs is more costly in political economy terms. 


\section{FRACTALS AND THE FINAL FRONTIER: MULTILATERALISING THE FTAS}

If the reasoning above holds, staging-post 2010 will consist of a world where almost all major trade flows are duty free, but the lack of tariffs will be founded on a motley assortment of regional, unilateral and multilateral arrangements. This section turns to the final step on the path to global free trade, namely the multilateralisation of the FTAs that would turn the major trading nations into a worldwide tariff-free zone.

\subsection{Fractals: Solution to one is solution to all}

Fractals have a strange property often explained by analogy with the Norwegian coastline. ${ }^{34}$ Type Norway into Google Earth and you will see a thousand kilometres of jagged coastline. As you zoom in from the space view to a stretch of coastline that is 10 kilometres long or 1 kilometre long or 1 metre long, you see roughly the same jagged line. The world's trade system is now marked by something like this.

In 2010, trade arrangements in Asia should involve three areas of reasonably well functioning regionalism (around Japan, Korea and China). Memberships in these areas however will be overlapping and intersecting. In short, the East Asian trade bloc will itself consist of fuzzy and leaky sub-blocs. Likewise, the North American bloc consists of a number of sub-blocs, notably the bilaterals surrounding the US, Mexico and Canada. Membership in these areas is overlapping and intersecting, so North America can be thought of as consisting of fuzzy, leaky sub-blocs. Things in Europe are only marginal less confused. The EU has a network of bilaterals that encompasses almost all of its neighbours, but some of the neighbours have their own free trade areas and FTA networks. Membership in these areas is overlapping and intersecting, so Europe can be thought of as a bloc that consists of fuzzy and leaky subblocs. Finally, the pattern reproduces itself at the world level. Although there will be three regional trade blocs in 2010, membership in the areas is overlapping and intersecting. The world will be a fuzzy, leaky trade bloc. In this way, the configuration of world trade arrangements can be thought of as being marked by fractals - the fuzzy, leaky nature of the world system is echoed in each of the Big-3 blocs, and their sub-blocs.

There is a reason for characterising the system of world trade relations as fractal. It tells us that the 'end game' in the path to free trade for the world as a whole is logically equivalent to the path to harmonious free trade within any given region. Or at least there are strong elements of symmetry in the problems. This is important since the world has seen two successful efforts in taming the tangle - one covered most sectors but was geographically limited, the other covered the world but was limited to a single sector. Europe did it in the late 1997 by 'multilateralizing' the tangle of FTAs in Europe. ${ }^{35}$ As mentioned, the multilateralising vehicle was the Pan-European Cumulation System. The second example was the 1996 Information Technology Agreement (ITA); this tamed the tangle of preferences and rules of origin governing trade in Information Technology (IT) goods in a very different way. Instead of harmonising rules of origin and cumulation, it made the motley assortment of trade deals irrelevant by binding MFN tariffs at zero for a set range of IT goods.

\subsection{How PECS tamed the European Spaghetti bowl}

The way in which PECS tamed the tangle of FTAs in Europe contains many lessons for the multilateralisation of regionalism on a global scale. In particular, it is critical to understanding the political economy forces that brought PECS to life. The basic political economy logic is simple. The spaghetti-bowl syndrome teamed with the unbundling of manufacturing processes altered the array of political economy forces in Europe. Quite specifically, unbundling and off-shoring from the EU meant that many EU firms that were previously protected by, or indifferent to Europe's spaghetti bowl now became victims of the spaghetti-bowl rules. This political economy re-alignment ultimately led to a policy that reversed the spaghetti bowl. Or, to put it colloquially - the spaghetti bowl came to act as a building block towards the creation of a coherent European free-trade zone.

To understand how unbundling and complexity rearranged EU political economy forces, it is necessary to define 'spaghetti bowl syndrome' more carefully and to understand the political economy forces that lead to the spaghetti bowl syndrome in the first place.

\footnotetext{
${ }^{34}$ A definition: "A rough or fragmented geometric shape that can be subdivided in parts, each of which is (at least approximately) a reduced/size copy of the whole."

${ }^{35}$ See Baldwin (1994) for a discussion of how: "A web of trade deals can create a nightmarish tangle of administrative procedures that raise costs for enterprises and for governments. Most costly of all, are those dealing with rules of origin (p.131)." Also see the proposal to multlateralise the Europe Agreements (Chapter 9).
} 
The first task is easy and best tackled by thinking of why a network of bilateral FTAs in a three nation world might not reproduce MFN free trade. This brings out the two distinct features of the spaghetti bowl: 1) different rules of origin and/or the exclusions of different lists of sensitive goods can mean that the three bilaterals could produce trade that is less than fully free, and 2) bilateral cumulation as opposed to diagonal or full cumulation can distort the purchase pattern of intermediate inputs in a way that does not occur under MFN free trade (see Box 2 for definitions). For short, we refer to these two symptoms of the spaghetti bowl syndrome as non-harmonised ROOs and bilateral cumulation.

The second task is to identify the political economy factors that produced the spaghetti bowl in the first place.

\subsubsection{Political economy forces that create the spaghetti bowl syndrome}

Start from the assertion that the spaghetti bowl syndrome does not emerge by mistake. Rules of origin and/or exclusions and cumulation rules affect the fortunes of organised lobbies and so are influenced by the usual political economy considerations, with a few twists (Destler 2003). The politically optimal structure of a given bilateral FTA depends upon the comparative advantages of the two nations and the particular political strengths of various interest groups at the time the deal is signed. For example, an EU producer may be worried about competition from Czech glass producers, but the Polish glass industry may not be worried by Czech competition (say Czech and Polish firms produce for different market segments). Since obtaining protectionist ROOs or exclusions is expensive for the industry and granting such exceptions is politically expensive for governments, it should not be surprising to see one set of ROOs governing the EU-Poland FTA while another set of ROOs governs the Czech-Poland FTA. Moreover, the Czech competition might have been more of a political economy problem to EU industry in 1991 than it was in 2005, if for example, most of the EU's crystal industry had been off-shored to the Czech Republic in the meantime. Thus it should not be surprising to see the glass ROOs that the EU imposes on FTAs signed in 2005 look different from those it signed in 1991. In a nutshell, think of restrictive ROOs as a way of granting Article-24 consistent protection to very narrowly defined import competing sectors. Since the special interests driving the protection vary across bilateral trade relationships, it is natural that the ROOs will differ for different bilateral trade agreements. This is the driving force behind the non-harmonised-ROOs part of the spaghetti bowl.

The political economy of bilateral cumulation is different. Take the example of the hub-and-spoke bilaterals that the EU's signed with Hungary and Poland in the 1990s. Suppose EU cloth industry competes directly with Polish cloth firms, and suppose the EU industry wins protectionist ROOs on cloth that forces all shirts imported duty-free into the EU market to be made either of EU cloth or of locally produced cloth. When cumulation is bilateral, the ROO will force Hungarian shirt producers to switch from buying Polish cloth to buying EU cloth in order to get duty-free status for their shirts in the EU. In this way, protectionist ROOs twined with bilateral cumulation can boost the operating profit of EU-based cloth producers. In this case, the bilateral cumulation plus ROO acts like a Hungarian tariff on Polish cloth - a tariff that provides EU producers with an advantage in the Hungarian market. By contrast, diagonal cumulation - which would allow the Hungary shirt-makers to use Polish cloth in meeting the ROOs - would not shift sales to EU cloth makers. The main point is that the same ROO can boost EU clothproducers' profits much more when it is combined with bilateral cumulation. Of course, the bilateral cumulation harms the Polish cloth-makers, but they have little political economy leverage in the EU-Hungary FTA negotiations. In a nutshell, supply switching is the driving force behind bilateral-cumulation aspects of the spaghetti bowl.

\section{Box 2: Bilateral, diagonal and full cumulation}

Bilateral cumulation is where inputs originating in one country are considered as originating in the other. This is a feature of all FTAs.

A diagonal cumulation 'zone' is to bilateral cumulation as customs unions are to FTAs. Under diagonal cumulation, a set of nations adopt a common set of ROOs, i.e. the zone becomes what might be called a 'ROOs union.' Once a product enters the diagonal cumulation zone, its origin is determined by the common ROOs and it can never lose its origin status by crossing a border internal to the zone. This means that ROOs cease to influence the choice of suppliers among nations that are members of the zone.

Full cumulation only works in customs unions, i.e. a set of nations that have both common ROOs and common tariffs on external trade. This means that any product that is physically inside the customs union has both paid the common external tariff and complied with the common ROOs. 


\subsubsection{Political economy logic of PECS}

Given the political economy logic discussed above, the emergence of a spaghetti bowl syndrome in Europe in the 1990s should have been expected. What may not have been expected is the volte-face that occurred in 1997 with the implementation of PECS. To understand the shift, it is necessary to identify the changes that re-arranged the political economy forces that produced the European spaghetti bowl. The focus here is on the globally-observed phenomenon of 'unbundling' of manufacturing processes.

As the 1990s progressed, competition from low-wage nations mounted just as the cost of trading goods and ideas fell rapidly. In Europe, as elsewhere, staying competitive required firms to scour the world for the cheapest inputs and often this entailed the establishment of complex supply networks in which components were shipped among many nations at various stages of processing. As part of this, EU firms often found it profitable to unbundle their manufacturing process and off-shore the production of some components to low-wage-low-productivity nations, such as those in Central Europe. The spaghetti bowl syndrome made it difficult to optimise manufacturing. Some final good have hundreds of intermediate inputs, some of which pass through several nations during their production. This made the spaghetti bowl syndrome a nightmare for many European businesses.

Close examination of this story reveals that unbundling undermined political economy support for the spaghetti bowl in two distinct ways. First it weakened the demand for ROOs/cumulation protection since it reduced the size of the import-competing industry that was initially protected (typically low-wage-labour intensive sectors). Some of the EU-based production that was protected by the rules of origin and bilateral cumulation shut down or moved offshore in response to new opportunities (the opening of the CEECs and market reforms in Mediterranean economies, for example) and new competitive pressures (the emergence of China, for example). Second, it raised the cost of supplying ROOs/cumulation protection since some of the EU firms that unbundled their manufacturing processes now had plants on the other side of the trade barriers. In essence, unbundling meant that 'us' became 'them.' Some of the EU firms that had lobbied for protectionist ROOs/cumulation in the early 1990s now became victims of those same policies. Taking up the last point for closer inspection, it is useful to note that the spaghetti bowl harms the delocated EU firms in two ways. First, the bilateral cumulation in the EU's hub-and-spoke FTAs with the CEECs hindered the EU firms now based in the 'spoke' economies from sourcing their inputs most efficiently. Taking up the example from above, recall that the EU shirt-maker had previously been unaffected by the EU's bilateral cumulation and ROOs on cloth (when the EU shirt-maker was located in the EU, the ROOs and bilateral cumulation had little impact). Now, when it moved some production to Hungary, the ROOs/cumulation 'forced' it to buy from the EU even if Polish cloth was cheaper. Second, now that the EU firm is located in Hungary, its shirts were subject to multiple ROOs. The EU-Hungary rules for the shirts it ships to the EU on one hand and the Hungary-Poland ROOs for its shipments to Poland on the other hand. Arranging production structures to satisfy two sets of ROOs is costly as is maintaining two sets of documentation necessary to obtain the two origin certificates. 


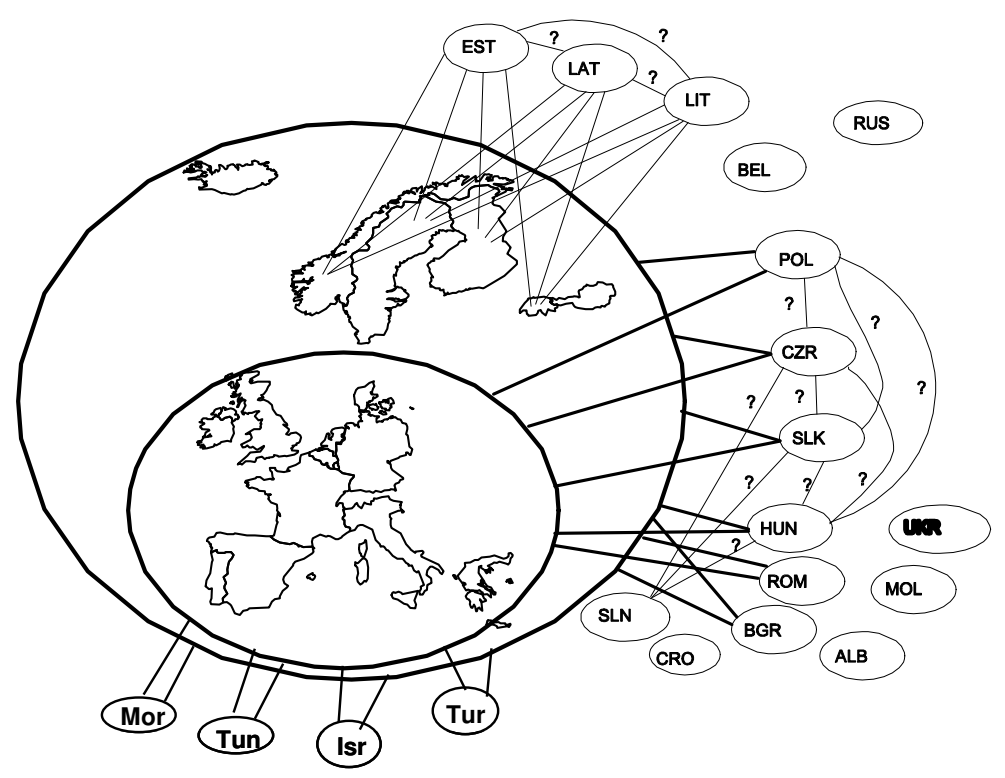

Figure 10: European spaghetti bowl, early 1990s.

Source: Baldwin (1994) figure 9.1.

What all this meant was that some EU firms, even some of those that pushed for the spaghetti bowl in the first place, now pushed the EU to make two changes: 1) to harmonise rules of origin so as to avoid the cost of meeting the actual and documentary requirements of multiple sets of rules of origin, and 2) to allow diagonal cumulation, so firms in the 'spoke' economies could source inputs from any nation in the PECS system without fear of losing the origin status on their sales to the EU.

Of course, a complete analysis of the situation would require examination of the changes in the political economy alignment in the 'spoke' economies as well, but given the hugely asymmetric export dependence of the spoke economies on the EU, the EU was in the driver seat when it came to reform. The switch was made even easier since most of the spokes (the CEECs) hoped to be EU members in just a few years.

In a nutshell, the unbundling of manufacturing processes in the face of the spaghetti bowl syndrome realigned the array of political economy forces that produced the spaghetti bowl in the first place. Practically, this meant amending all their various FTAs by substituting a common set of rules of origin, and allowing for diagonal cumulation. The resulting PECS was extended to Turkey in 1999 and the EU is extending it to the Euro-Med FTAs by 2010. Note that a domino-like effect is triggered by PECS. A nation like Tunisia would be willing to adopt this common set of rules since being outside PECS raises the cost of doing business in Tunisia compared to, say, Turkey. In this way, being outside may encourage investment diversion to PECS members and so PECS has created a domino effect of its own - not in terms of tariffs (these have already been or will be eliminated by the Euro-Meds) but rather in terms of ROOs/cumulation protection.

To sum up, the spaghetti bowl created a new political economy force - independent of the juggernaut and the domino effects - that pushed the European trade bloc to transform itself from a fuzzy, fragmented matrix of bilaterals into a relatively harmonious regional free trade zone for industrial goods. See Figure 10 and Figure 11. 


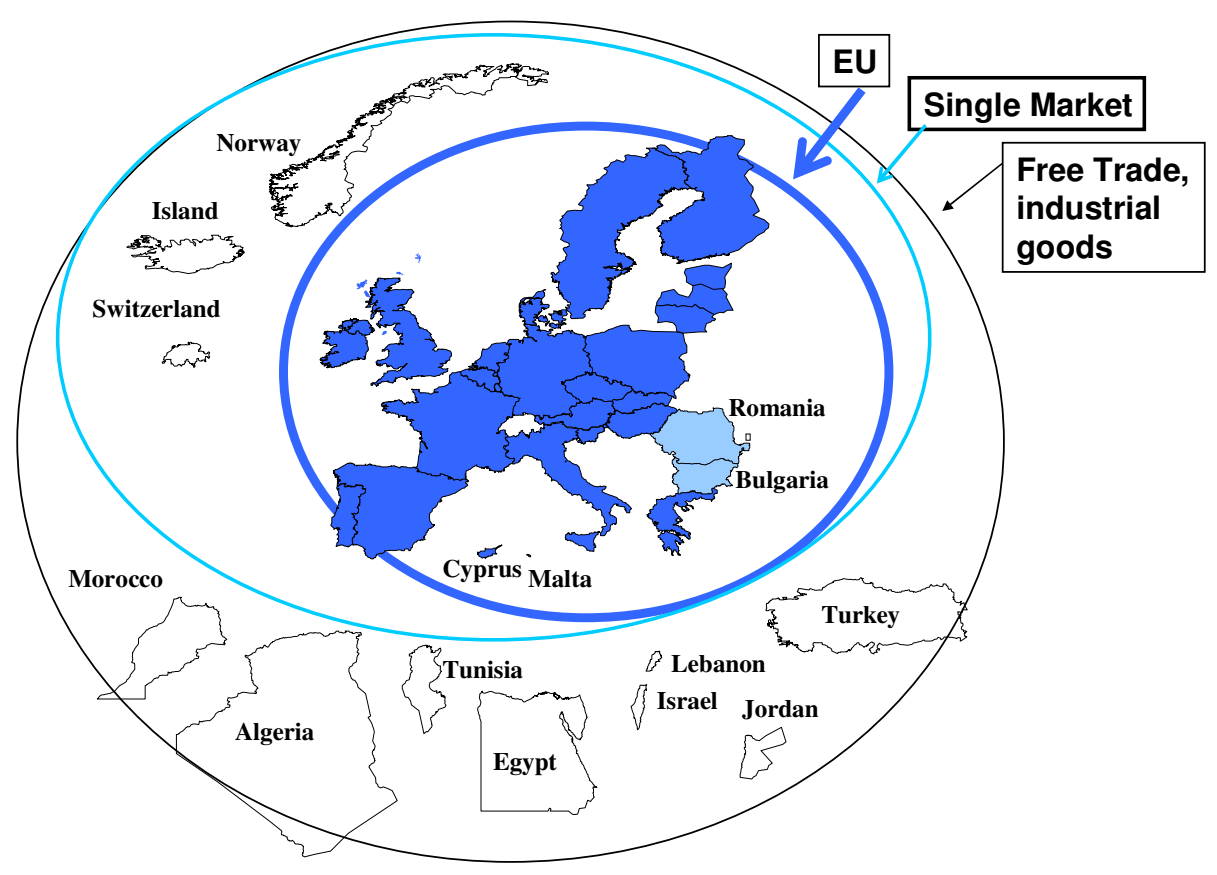

Figure 11: Euro-Med trade bloc with PECS extended to Meds.

\subsubsection{Spaghetti bowls as building blocks}

Here we extract the general political economy logic from the PECS experience so as to apply to other regions. The key elements are:

- Easily understandable political economy forces result in the spaghetti bowl syndrome. ROOs and exclusions engage political economy forces that are pair-specific, rather than economy specific, so it is natural that the resulting endogenously chosen pair-specific trade policy (e.g. rules of origin and cumulation) differ across bilateral FTAs. The natural result is a tangle of uncoordinated and often conflicting rules of origin and bilateral cumulation.

- Unbundling of the manufacturing process erodes political support for existing ROO/cumulation protection since it downsizes the import-competing industries that benefited from them.

- Unbundling also creates new political economy opponents of the ROO/cumulation protection embedded in the spaghetti bowl since it places on the other side of the ROO/cumulation barriers some of the firms that previously either benefited from or were indifferent to the ROO/cumulation protection.

- Unbundling also creates new political economy opponents to multiple sets of ROOs in that it moves into spoke economies some of the firms that were previously located in the hub economy (and therefore only had to deal with one set of ROOs). This location change means that the formerly hub-based firms now face the tangle of ROOs that had previously only bothered spoke-firms. To the extent that these newly delocated firms have greater political clout in the hub economy than did firms of spoke nationality, this shift will tend to prompt the hub towards pushing for harmonisation.

\subsection{The Information Technology Agreement (ITA)}

World trade in Information Technology (IT) goods was quite free in the mid-1990s due to a motley assortment of unilateral trade liberalisation (especially in East Asia), regional trade liberalisation in Europe and North American, and multilateral tariff cutting (especially the US and Japan). This did not make the world into a free trade zone for IT goods. Bilateral cumulation and mismatching rules of origins hindered trade and made it hard for IT producers to optimise their production networks globally.

In 1996, the major IT-producing nations met under the WTO's auspices and agreed to bind their MFN tariffs at zero for a specific list of IT goods including computers, telecommunications, semiconductors, semiconductor 
manufacturing equipment, software, instruments and apparatus. ${ }^{36}$ The ITA is a package deal in that no productcoverage exceptions are allowed. The deadline for zero tariffs is 2000, although some developing nations had longer phase in period (2005 was the longest delay possible). The ITA zero-tariff bindings are on an MFN basis and so available to exporters from any WTO member.

The ITA was initiated by the US and attracted staunch support from the EU, Japan and Canada. The deal was clearly aimed at establishing global free trade in the sector. A key proviso in the 1996 deals was its 'critical mass' clause that stipulated that it would come into effect only if nations accounting for at least $90 \%$ of world IT trade had signed. The original negotiators did not meet this threshold in 1996, but nine more nations signed up by the March 1997 deadline and the agreement came into force (Bora 2004).

Why did nations agree to cut tariffs? First it should be noted that the US, Japan and most major East Asian producers were already applying near duty free status to IT products even before the ITA. The EU had high tariffs on semiconductors, but EU semiconductor production stagnated while its consumption of chips grew rapidly (ESIA 2005). This evolution shifted the political power from the EU industry that benefited from protection to the EU industry that suffered from it. More generally, the IT sector is marked by production unbundling on a global scale. An example of the production unbundling in a particular IT product can be seen in Figure 12. As in the case of PECS, former beneficiaries of complexity were now victims. Given this realignment of the political economy forces in the sector, it is easy to understand why tariffs that had previously been politically optimal to impose where now politically optimal to remove.

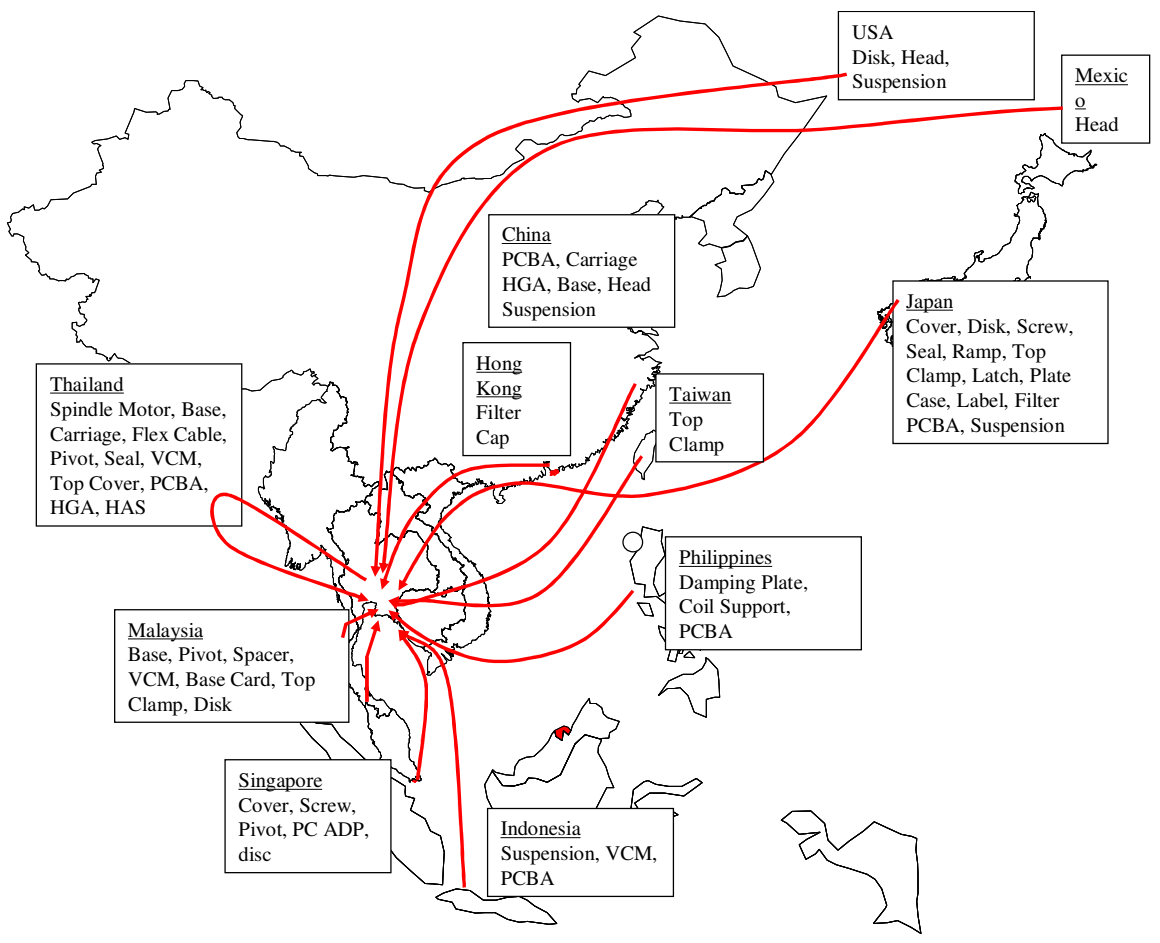

Figure 12: An example of global production unbundling in an IT good.

Note: This shows the nations where parts are sourced for a hard-disk drive assembled in Thailand; the disk drives are then shipped on to various markets to be used in various electronic goods.

Source: Baldwin (2006, a) adapted from Hiratsuka (2005).

Just as with PECS, the ITA created a domino effect as smaller nations signed up to the ITA as a means of boosting the attractiveness of their nation to foreign IT producers. A steady stream of WTO members has signed the ITA; there are now 63 signatories which account for about 97 percent of world IT trade (Bora 2004).

${ }^{36}$ See Bora (2004) and Bora and Liu (2004) for analysis of the ITA. See www.wto.org for a negotiation history, and AITIC (2006) for the latest developments. 


\subsection{Leap of faith: Spaghetti bowls and the final frontier}

To date, the spaghetti bowl complexity of North American and East Asian trade arrangements have not created the sort of spaghetti-bowl-as-building-block (SBBB) political economy forces seen a decade ago in Europe. In East Asia the problem has been avoided hereto since only one RTA had been substantially implemented - AFTA - and it was rarely used by traders; its ROOs/cumulation protection have no bite. Instead, East Asians unilaterally cut their applied MFN tariffs on the items that might have caused complexity-problems for East Asian firms. All this could change because East Asia has signed itself up for a truly massive degree of complexity - the East Asian noodle bowl. By 2010, there should be well over 90 FTAs affecting bilateral flows in East Asia as shown in Figure 13. ${ }^{37}$

\section{Figure 13: The East Asian 'Noodle bowl’ syndrome.}

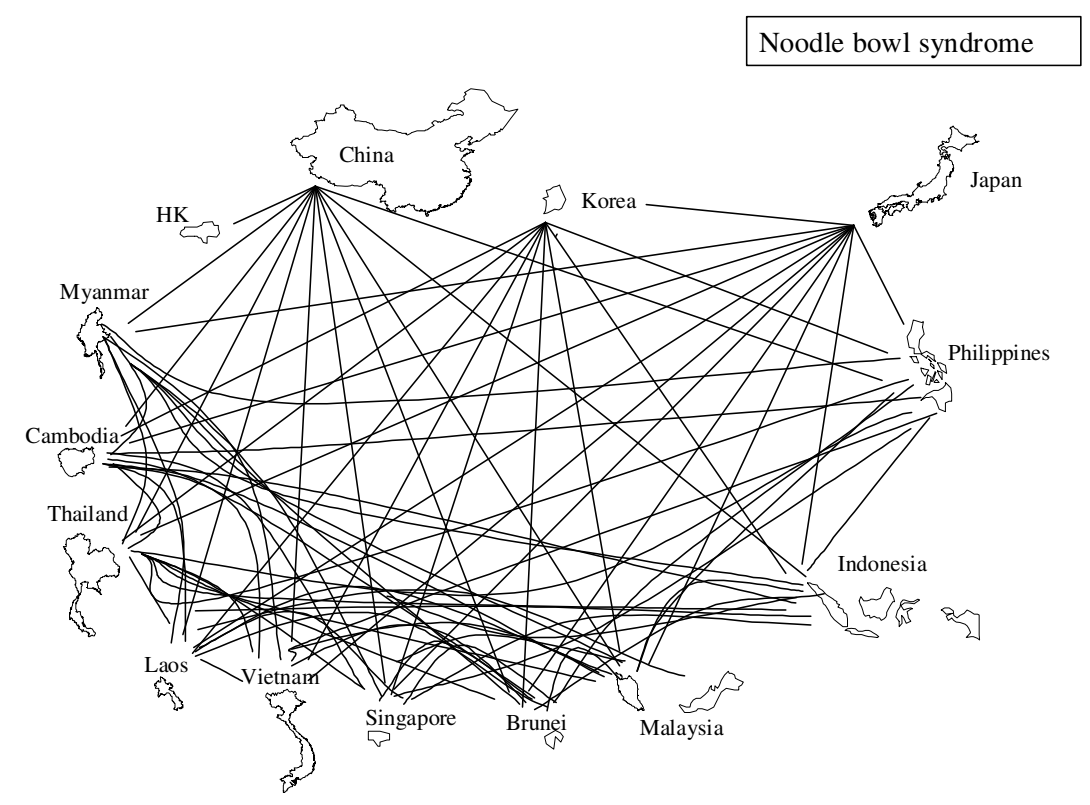

Note: The map shows FTAs signed or under negotiation in January 2006. East Asia is defined here as the 10 ASEANs, China, Japan and Korea. Source: Baldwin (2006a, Figure 1).

This might not lead to a 'noodle bowl' problem, however, since the PTAs might not get used. East Asian may engage in de facto unilateralism while they talk about de jure regionalism. That is, they may simply cut their MFN applied rates in line with their preferential rates, so the preferential rates (and attendant rules of origin and cumulation) remain irrelevant. This would be a case of RTB unilateralism preventing complexity from being an issue. While there is a good chance that some aspects of this will occur, it is unlikely to occur in more sensitive items such as trade in assembled cars or other high-end products. ASEANs and China still believe that protecting such industries is a good way of promoting them, and the industrial might of Korean and Japanese carmakers implies that there will be a big difference between unilateralism and bilateralism in this industry. If this happens, then the combination of complexity and unbundling may create a new political economy force in the region that pushes for a PECS-like solution. If this analysis is correct, East Asian multinationals would provide the initial push.

In North America, the spaghetti-bowl-cum-unbundling problem is much less severe since the US has de facto imposed hub-and-spoke harmony on its FTAs in the Americas. So far, US off-shoring to the region has not created a "Factory Americas" akin to Factory Asia. Consequently, US firms have only just begun to suffer from the spaghetti bowl syndrome in the Western Hemisphere. While this may begin to change - especially if rapid growth in Mexican incomes continues - there are other sources of new political economy pressures. The US's hub-and-spoke

${ }^{37}$ See Baldwin (2006a) for a more detailed count. 
bilateralism disfavours industrial location in the "spokes. ${ }^{38}$ Because nations like Mexico and Costa Rica have no hope of changing this system, the most likely outcome is that their own manufacturing sectors will push for a region-wide application of US rules of origin. The political economy force here is that harmonisation of such rules boosts the spoke's competitiveness as a location for US firms. (US firms would have to follow only a single set of ROOs to get free-trade access to both the big US market and all the spoke's FTA partners.)

The only thing missing at that point would be diagonal cumulation. Thinking about the future, there is a scenario where the US would push for diagonal cumulation. If rising Mexican wages keeps the unbundling process on track, US firms may delocate production to other Western Hemisphere nations and thus lose the benefits of NAFTA's harmonious ROOs. Under this conjecture, some of the US firms that asked for the complexity in the first place may find themselves victims of it. The next step would be for the US to lead talks that formalised the adoption of NAFTA ROOs and institutionise diagonal cumulation. Just as a domino-like logic is spreading PECS to the EuroMed arrangements, this process could easily spread to South America due to the overlapping membership of the North American and Southern Cone trade blocs.

The preceding constitutes two fairly daring pieces of extrapolated political economy logic. The prediction is that the fuzzy, leaky nature of the Big-3 trade blocs will - together with unbundling - create new political economy forces that transform each of the blocs into a coherent free trade zone for industrial goods. The argument can be taken even further out on a limb.

To date, the fundamental forces that have fostered unbundling - the drop in the cost of moving ideas, goods and people - have tended to result in regionalised unbundling. The reason is that the drop in the cost of moving ideas (IT and communications in general) has far outstripped the drop in the cost of shipping goods and this has far outstripped the cost reduction of moving people (executives, technical personal, sales and marketing people, etc.). Airfares have fallen but the opportunity cost of time for managers and skilled workers continue to rise with their wages. Regionalising off-shoring is thus a way of saving on the cost of moving people. ${ }^{39}$ As the costs of trade continue to fall, however, unbundling will tend to get more global. And this will mean that the differences between Europe's PECS, and East Asia's and NAFTA's PECS-like systems will start to create new political economy forces. These forces may mean that governments in the Big-3 blocs will find it politically optimal to reverse the complexity that they previously found it politically optimal to maintain. Under this scenario, the final step on the path to global free trade is forced by the spaghetti-bowl-as-building-bloc syndrome.

This may sound pie-in-the-sky, and it certainly is speculative, but there is a precedent - the ITA. As discussed above, IT tariffs in the major producing and consuming nations were quite low in the mid-1990s, and much of the trade occurred duty free under the aegis of various RTAs. This meant that the policy distance to global free trade was not great. All that was needed was a mild push from a significant fraction of the global producers and a bit of race-to-the-bottom-liberalisation logic to pull in the rest. The result was ITA. Observe that the ITA tamed the tangle by making ROOs and cumulation irrelevant.

\section{CONCLUDING REMARKS: WHAT COULD THE WTO DO?}

What role might the WTO play in multilateralising regionalism and promoting the final steps to global duty-free trade? The introduction mentioned two key facts that condition any answer to this question. 1) Regionalism is here to stay. 2) The motley assortment of unilateral, bilateral, plurilateral and multilateral deals is a poor way of running the world trade system. A third fact can be added here: 3) The WTO has been little more than an "innocent bystander" in the massive spread of regionalism.

These facts lead naturally to a stark conclusion. The WTO risks a serious erosion of its relevance if it continues in its "innocent bystander" role. Moreover, the WTO is probably the only international organisation that is well-placed to help tame the tangle of free trade deals at the global level; it is probably the only international organisation that has a clear incentive to do so.

The two examples of multilateralising regionalism - PECS and the ITA - stand in stark contrast with respect to the WTO's role. PECS was conceived, negotiated and implemented by one of the world's trade hegemons - the EU.

\footnotetext{
${ }^{38}$ See Baldwin (1994 Chapter 5) and Baldwin (2004) for the economics of hub and spoke bilateralism and its impact on industry location.

${ }^{39}$ I thank Gary Hufbauer for sharing this (and many other) insight with me.
} 
The WTO was an "innocent bystander" in the process. ${ }^{40}$ Although the PECS members adhered to the letter of the law, and the WTO's lack of engagement was in line with historical precedent, there are good reasons for thinking that it should have been otherwise. Recent research has demonstrated that PECS harmed the export interests of WTO members excluded from the club (Augier, Lai and Gasiorek 2005). Moreover, given the size of the PECS markets, nations who were not part of the original scheme are being induced/forced to join it in order to avoid the harmful impact of staying out (although of course enlargement of PECS membership is driven by carrots as well as sticks). The ball that PECS started rolling is likely to affect a growing list of WTO members - none of which are likely to have a substantial say in the arrangement given the EU's commercial dominance. The original GATT was set up quite precisely to discipline such 'spillovers' so one might have thought that PECS would have been a natural topic for WTO discussions.

It is worth noting that there might have been a strictly legal case for WTO intervention. From a purely legal point of view, the recent research on the impact of rules of origin (Cadot et al 2006) suggests that a sufficiently strict interpretation of Article 24 would consider rules of origin as subject to WTO discipline. ${ }^{41}$ Fifty years of practice however have rendered this discipline non-applicable. Given this, and absent an Appellate Body decision that reversed this non-application, the legal route for WTO influence appears to be blocked. Given this limited mandate, the WTO could not have influenced the PECS talks in any direct manner, but it might have helped in its 'fair broker' role.

The main issues involved in the multilateralisation of FTAs turn on rules of origin, rules of cumulation and the economic spillovers on third nations. These are immensely complex and involve a very subtle economic and legal logic. The WTO could help WTO members in future PECS-like arrangements by providing unbiased research on the impact of such arrangements, especially concerning the impact on excluded WTO members. Solid, non-partisan research on such issues could ensure that future PECS-like arrangements take better account of excluded nations. Such efforts would help to identify critical issues for any future step towards multilateralisation of FTAs. It would also alert the dominant members of the WTO that these seemingly regional and seemingly technical issues may have broader implications that merit multilateral discussion. For example, the political economy forces that led the EU to multilateralise its tangle of FTAs may eventually induce the US to impose a PECS-like solution on the tangle of FTAs in the Western Hemisphere. As with PECS, such a move would be likely to harm the export interest of excluded WTO members and induce/force WTO members in the Western Hemisphere to follow the hegemon's initiative.

The WTO's role in the ITA was very different. The ITA resulted from negotiations conducted under the WTO's aegis (it was a leftover from the Uruguay Round). The outcome was non-discriminatory; any nation is free to join the club. Lessons can be drawn from the structure of the ITA initiative. The ITA was very much in the spirit of the early GATT tariff talks. The ITA was driven by the world's major IT exporters, but it was done within the WTO context. 29 major IT exporters negotiated and signed a declaration that committed them to zero bound MFN tariffs on the negotiated list of information technology products. There was no hegmon involved, or rather there were several so none played a hegemonic role. Given this structure, the ITA naturally took into account a much broader range of concerns about 'spillovers' than might have been the case if it had been, for example, a US-led initiative outside of the WTO's framework. The original signatories agreed, inter alia, to consult with other participants as requested and to encourage other WTO members to accede to the deal. Perhaps PECS might have included such elements if the WTO had been more involved.

It is perhaps impossible to generalise from the two instances, but it seems plain that the WTO's involvement in the ITA produced a multilateralisation of regionalism that was much more open and less hegemonic than PECS. It would seem important to study the political economy of the ITA more closely to determine the critical factors that allowed the WTO's participation in the ITA. Such research would yield lessons for future multilateralisation initiatives.

\footnotetext{
${ }^{40}$ The new 'Transparency Mechanism', recently agreed by WTO members, should speed the Committee on Regional Trade Agreements' work. For details see http://www.wto.org/english/news_e/news06_e/rta_july06_e.htm .

${ }^{41}$ Paragraph $.5 \mathrm{~b}$ ) of article 24 states as one of the conditions on FTA formation that: "the duties and other regulations of commerce maintained in each of the constituent territories and applicable at the formation of such free-trade area or the adoption of such interim agreement to the trade of contracting parties not included in such area or not parties to such agreement shall not be higher or more restrictive than the corresponding duties and other regulations of commerce existing in the same constituent territories prior to the formation of the free-trade area." Emphasis added. Recent empirical research (Cadot et al 2006) has shown that ROOs do act as trade barriers and so should in principle be subject to the XXIV.5 b discipline.
} 
More generally, the ITA's reliance on negotiations - as opposed to legal routes - would seem to hold many lessons for how the WTO could most effectively guide the multilateralisation of regionalism. One of the WTO's great assets is its role as a convenor. Regional attempts to multilateralise FTAs - attempts that may well occur in East Asia and the Western Hemisphere in the future - would seem like an excellent opportunity for the WTO to convene discussion among the major players on this topic. It is quite clear that there are 'spillovers' on excluded WTO members; negotiations or even discussions on the issues might well reveal areas where mutually beneficial agreements might be found.

An example can be found in the issue of the harmonisation of rules of origin. To date, this has been done primarily in a regional, hegemonic manner - by the EU in Europe and by the US in North and Central America. ${ }^{42}$ While rules of origin for FTAs in some sensitive sectors are political landmines, it would seem possible to develop global standards for preferential rules of origin in less sensitive sectors. After all, organisations such as the International Standards Organisation (ISO) manage to set, via negotiations, common standards on many but not all products. Likewise, it would seem that the WTO could start something like the ISO of FTA rules of origin. As globalisation proceeds, resistance to such harmonisation is likely to recede in non-sensitive sectors while the gains from such harmonisation are likely to multiply. Specifically, the trend to heightened competition from low-wage nations and the unbundling and off-shoring of manufacturing stages will increasingly reduce the size and number of firms that are protected by non-standard ROOs. At the same time, the unbundling and offshoring means that a growing list of firms (especially multinational firms based in the most powerful WTO member states) might gain from the standardisation of ROOs as more sectors may come to resemble the IT sector. In other words, the gains from cooperation multiply in a world where 'us' is increasingly confused with 'them.' A well-timed initiative by the WTO might set up a negotiating framework that might become increasingly useful in the future.

The two roles suggested here for the WTO - providing clearer information and a deeper understanding of the effects of the multilateralisation of regionalism on the one hand, and setting up a negotiating forum for the coordination/standardisation/harmonisation of rules of origin and cumulation on the other - might be usefully augmented by a third. One of the most noxious aspects of regionalism for the world trade system is its tendency toward the law of the jungle. In multilateral trade negotiations, the principles of reciprocity and MFN, and the presence of multiple hegemons curb the power of nations with big markets to force/cajole small-market nations into accepting less-than-fully even-handed deals. For example, it is remarkable to see how developing nations are willing to accept disciplines in FTAs on intellectual property rights, investment measures, government procurement and agricultural that they reject at the WTO level. While there may be many reasons for this, one key element is the enormously asymmetric dependence of these nations on the hub's market compared to the hub's dependence on the spoke's market. Just think of Costa Rica and the US.

Since this marked asymmetry is observed in all regions of the world, the WTO might think about convening a forum of 'spokes' that would explore that possibility of mutually advantageous cooperation on hub-spoke FTAs in different regions of the world. Given the political economy realities of regionalism, such a forum could not hope to reverse the asymmetries in bargaining power, but it might achieve useful scale economies in the more technical aspects of FTA negotiations. Faced with the massive legal and economic analytic resources of a hub economy like the EU, US or Japan, small-nation FTA partners may find that their 'hand' at the negotiation table is even weaker than it need be. This suggests the setting up of something like the Advisory Centre on WTO Law but one specifically devoted to North-South and South-South FTAs. A corresponding economic analysis service for FTAs might also be useful to developing members of the WTO. An example can

Regionalism is here to stay. Arguments over the merits of regionalism versus multilateralism are useful and will continue, but as far as the world trade system is concerned, it seems that regionalism must be taken as a fact of life. One way forward would be to foster the multilateralisation of FTAs. The WTO is well-placed to play a constructive role in this process. Indeed, it is hard to think of any organisation that could play this role better than the WTO.

\section{REFERENCES}

ADB (2006). Asian Development Outlook 2006. Asian Development Bank, Manila. http://www.adb.org/

\footnotetext{
${ }^{42}$ The WTO's efforts on rules of origin are limited to non-preferential rules of origin. See “Agreement on Rules of Origin,' on www.wto.org
} 
Aghion, P., P. Antras and E. Helpman (2004). Negotiating Free Trade. NBER Working Paper 10721.

AITIC (2006). "Information Technology Agreement (ITA): A Tool for Narrowing the Digital Divide?, Information Brief N 8. www.acici.org

Anderson, K. and H. Norheim (1993), 'Is World Trade Becoming More Regionalized?', Review of International Economics, Blackwell Publishing, vol. 1(2), pages 91-109, June.

Ando, M. (2004). Fragmentation and vertical intra-industry trade in East Asia. 21st Century COE Discussion paper No.2004-25; Forthcoming North American Journal of Economics and Finance. http://lowe.claremontmckenna.edu/events/pdf/AndoPaper022505.pdf

Ando, M. and Kimura, F. (2005). The formation of international production and distribution networks in East Asia. In T. Ito and A. Rose (Eds.), International trade (NBER-East Asia seminar on economics, volume 14), Chicago: The University of Chicago Press. First version, NBER Working Paper 10167.

Augier, P. M. Gasiorek and Charles Lai Tong (2005). "The impact of rules of origin on trade flows," Economic Policy, Issue 43, July.

Augier, P. M. Gasiorek and Charles Lai Tong (2005). “The impact of rules of origin on trade flows,” Economic Policy, Issue 43, July.

Augier, P.. M. Gasiorek, Charles Lai Tong (2005). “The Impact of Rules of Origin on Trade Flows," Economic Policy.

Bagwell, K. and R. Staiger (2002), The Economics of the World Trading System (Cambridge MA: The MIT Press).

Bagwell, K. and R. Staiger, (1999), 'An Economic Theory of GATT', American Economic Review, vol. 89(1), pages 215-248, March.

Bagwell, Kyle and Robert Staiger (2002). The Economics of the World Trading System, MIT Press, Cambridge.

Baldwin, Richard (1987). "Politically Realistic Objective Functions and Trade Policy: PROFs and Tariffs", Economic Letters, 24, pp 287-290, 1987.

Baldwin, Richard (1993a), 'A domino theory of regionalism', NBER WP 4465 (Cambridge). Published as: Baldwin, Richard E. (1995), 'The domino theory of regionalism', in Baldwin, Haaparanta and Kiander (eds.), Expanding membership of the European Union (Cambridge: Cambridge University Press). Republished as Chapter 23 (pp 479-502) in J. Bhagwati, P. Krishna and A. Panagariya (1999), Trading blocs: Alternative approaches to analyzing preferential trade agreements, Cambridge: MIT Press.

Baldwin, Richard (1994). Towards an Integrated Europe, CEPR Press, London. http://hei.unige.ch/ baldwin

Baldwin, Richard (2000), 'Regulatory Protectionism, Developing Nations, and a Two-Tier World Trade System,' Brookings Trade Forum: 2000, (Washington DC: Brookings Institution).

Baldwin, Richard (2002). "Asian Regionalism: Promises and Pitfalls," http://hei.unige.ch/ baldwin. Published in East Asian Economic Regionalism: Feasibilities and Challenges, Ahn, Choong Yong; Baldwin, Richard E.; Cheong, Inkyo (Eds.), Springer, April 2005.

Baldwin, Richard and F. Robert-Nicoud (2002). "Entry and Asymmetric Lobbying: Why Governments Pick Losers," NBER WP 8756.

Baldwin, Richard and F. Robert-Nicoud, (2005), 'Juggernaut model - the Lego version', GIIS mimeo.

Baldwin, Richard and F. Robert-Nicoud, (2006), 'Protection for Sale Made Easy', CEPR Discussion Paper 5452 (London: Centre for Economic Policy Research).

Baldwin, Richard (2006, b), 'Globalisation: the great unbundlings(s)', paper prepared for the Finnish Prime Minister's Office for EU Presidency. www.vnk.fi.

Baldwin, Richard E. (1997). "The causes of regionalism," The World Economy, Vol. 20, No, 7, pp 865-888, 1997.

Baldwin, Richard E. and Robert E. Baldwin (1996). "Alternate Approaches to the political economy of endogenous trade liberalization," European Economic Review, 40, pp 775-782.

Baldwin, Richard, (1993b) “Asymmetric lobbying effects: Why governments pick losers," Mimeo, Graduate Institute of International Studies on http://heiwww.unige.ch/baldwin/. Presented at CEPR workshop in Stockholm \& discussed by Henrik Horn.

Baldwin, Richard, and Charles Wyplosz, (2006). The Economics of European Integration, McGraw-Hill. 2nd Edition.

Baldwin, Richard, and R. Forslid (2004), "Trade Liberalization with Heterogenous Firms" (May 2006). CEPR Discussion Paper 4635; 2006 version in NBER Working Paper 12192.

Baldwin, Richard, R. Forslid, P. Martin, G. Ottaviano, and F. Robert-Nicoud, Economic Geography and Public Policy (Princeton: Princeton University Press).

Baldwin, Robert (1976), ‘The Political Economy of Postwar U.S. Trade Policy', Bulletin, 1976 (4) (New York: New York University Graduate School of Business).

Baldwin, Robert (1976). "The Political Economy of Postwar U.S. Trade Policy", Bulletin, 1976-4, New York: New York Graduate School of Business.

Baldwin, Robert (1984) "The Changing Nature of U.S. Trade Policy since World War II," in R.E. Baldwin and A.O. Krueger (eds), The Structure and Evolution of Recent U.S. Trade Policy, Chicago: University of Chicago Press.

Baldwin, Robert (1985), The Political Economy of U.S. Import Policy, (Cambridge, MA: The MIT Press)

Baldwin, Robert (1985). The Political Economy of U.S. Import Policy, Cambridge, MA: The MIT Press.

Baldwin, Robert (2004) "Key Challenges Facing the WTO," in M. Moore (ed.), Doha and Beyond: The Future of the Multilateral Trading System, Cambridge, U.K.: Cambridge University Press.

Baldwin, Robert (2006) "Failure of the WTO Conference at Cancun," The World Economy, vol.26, no. 6, 677-696.

Bergsten, F. (1989), 'Fifty Years of the GATT/WTO: Lessons from the Past for Strategies for the Future', IIE Working Paper 1998-3 (Washington DC: Institute for International Economics).

Bergsten, F. (1998). "Fifty Years of the GATT/WTO: Lessons from the Past for Strategies for the Future", paper presented to the symposium on the world trading system "Fifty Years: Looking Back, Looking Forward", Geneva, Switzerland. www.iie.com.

Bhagwati, J. (1994). "Regionalism and multilateralism: an overview," in J. de Melo and A. Panagariya (eds), New Dimensions in

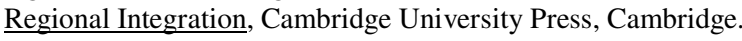


Bombardini, M. (2004).’Firm heterogeneity and lobby participation," MIT thesis chapter.

Bond Eric W. \& Jee-Hyeong Park (2002). "Gradualism in Trade Agreements with Asymmetric Countries," The Review of Economic Studies, Volume 69 Page 379.

Bond, Eric W., and Constantinos Syropolous (1996). "The size of trading blocs: Market power and world welfare effects," Journal of International Economics, Vol. 40, pp. 411-437.

Bora, B. (2004), 'Information Technology Agreement and World Trade', www.wto.org (Geneva: World Trade Organisation).

Bora, B. and X. Liu (2004), 'The Impact of Information Technology Agreement on Trade', mimeo, (Geneva: World Trade Organisation).

Brainard, S. Lael, and Thierry Verdier, 1997, "The political economy of declining industries: Senescent industry collapse revisited," Journal of International Economics, Vol. 42, pp. 221-237.

Brander, J. and P. Krugman (1983)

Brander, J. and P. Krugman (1983), 'A 'reciprocal dumping' model of international trade', Journal of International Economics, vol. 15, No 3-4, 313-321.

Cadot, Olivier, Antoni Estevadeordal, Akiko Suwa Eisenmann and Thierry Verdier (2006). The Origin of Goods: Rules of Origin in Regional Trade Agreements, Oxford University Press, Oxford.

Cadot, Olivier, Antoni Estevadeordal, Akiko Suwa Eisenmann and Thierry Verdier (2006). The Origin of Goods: Rules of Origin in Regional Trade Agreements, Oxford University Press, Oxford.

Candau, F, L. Fontagne and S. Jean (2004). "The utilisation rate of preferences in the EU." CEPII working document, Paris.

CEA (1991). Economic Report of the President, Council of Economic Advisors, Washington D.C.

Charnovitz, Steve (2002), Trade Law and Global Governance, London: Cameron May.

Charnovitz, Steve (2005), “The WTO in 2020, Journal of International Law and International Relations 1 (1-2), pp 167-190.

Chisik, Richard A. (2003). "Gradualism in Free Trade Agreements: A Theoretical Justification," Journal of International Economics. 59:2, pp. 367-397.

De Torre, A. and M. Kelly (1992), 'Regional trade arrangements,' IMF Occasional papers, No. 93 (Washington).

Destler, I. (2005), American Trade Politics, 4th ed. (Washington DC: Institute for International Economics).

Destler, I.M. (2003). “US Trade Politics and Rules of Origin: Notes Toward A Paper,'Workshop on Rules of Origin Paris, France, May 24, 2003. www.publicpolicy.umd.edu/faculty/destler/ROA.pdf

Destler, I.M. (2004). American Trade Politics, Fourth Edition, Washington, D.C.: Institute for International Economics..

Destler, I.M. (2005). American Trade Politics, Institute for International Economics, 4th edition, 2005.

Destler, I.M. and John Odell (1987). Anti-Protection: Changing Forces in US Trade Politics. Washington, DC: IIE.

Eaton, J., S. Kortum, and F. Kramarz (2004), 'Dissecting Trade: Firms, Industries, and Export Destinations', American Economic Review, 94, 2004, 150-154.

Eichengreen, B. and D. Irwin (1996). "The Role of History in Bilateral Trade Flows,” NBER WP 5565.

El-Agraa, A. (ed.) (1994) The Economics of the European Community, 4th edition, (New York: St Martin's Press).

ESIA (2005). “The European Semiconductor Industry: 2005 Competitiveness Report.” ESIA, Brussels. www.eeca.org

Ethier, W.J. (1998b). ”The New Regionalism,“ Economic Journal, Vol. 108, No. 449, pp1149-1161.

Ethier, Wilfred J, (2002). "Unilateralism in a multilateral world,” Economic Journal, Vol. 112, pp. $266-292$.

Ethier, Wilfred J. (1998) 'Reciprocity, Nondiscrimination, and a Multilateral World,' Penn Institute for Economic Research Working Paper No 99-001.

Ethier, Wilfred J., (1998a). "Regionalism in a multilateral world,” Journal of Political Economy, Vol. 106, pp. 1214-1245.

Evans, D. et al (2006), 'Assessing Regional Trade Agreements with Developing Countries: Shallow and Deep Integration, Trade, Productivity, and Economic Performance', University of Sussex mimeo.

Falvey, R., D. Greenaway and Z. Yu (2004), 'Intra-industry Trade Between Asymmetric Countries with Heterogeneous Firms,' University of Nottingham Research Paper No. 2004/05.

Findlay, R. and K. O'Rourke (2007), Power and Plenty: Trade, War and the World Economy in the Second Millennium (Princeton: Princeton University Press).

Findlay, R., and S. Wellisz, (1982), "Endogenous Tariffs, the Political Economy of Trade Restrictions, and Welfare", in Jagdish Bhagwati (ed.), Import Competition and Response, Chicago: University of Chicago Press.

Freudenberg, M. and T. Paulmier (2005), 'A Comparison of De Jure Economic Integration in East Asia: Is East Asia Discriminating Against Itself?' IDE working paper (Tokyo: Institute for Developing Economies, JETRO).

Freund, C. (2000) Different Paths to Free Trade: The Gains from Regionalism*. Quarterly Journal of Economics 115:4, 13171341.

Fukao, K., Ishito, H. and Ito, K. (2003). Vertical intra-industry trade and foreign direct investment in East Asia. Journal of the Japanese and International Economies 17, 468-506.

GATT (1953). World Trade, GATT Secretariat, Geneva.

GATT (1986), International Trade, 1985-86. (Geneva: General Agreement on Tariffs and Trade)

Gilligan, M. (1997), Empowering Exporters: Delegation, Reciprocity and Collective Action in Twentieth Century American Trade Policy. 1997 (Ann Arbor: University of Michigan Press).

Greenaway, D, C.Morgan and P. Wright (2002). Trade Liberalisation and Growth in Developing Countries, Journal of Development Economics, Vol. 67 (2002) pp.855-865.

Grossman, G. and E. Helpman (1994), 'Protection for Sale', American Economic Review, vol. 84(4), pages 833-50, September.

Grossman, G. and E. Helpman (2001), Special Interest Politics, (Cambridge MA: The MIT Press).

Grossman, G. and E. Helpman (2002). Interest Groups and Trade Policy, Princeton University Press.

Grossman, Gene M \& Helpman, Elhanan, 1994. "Protection for Sale," American Economic Review, vol. 84(4), pages 833-50.

Grunwald, J. and K. Flamm (1985). The Global Factory: Foreign Assembly in International Trade, Brookings Institution, Washington DC.

Helen Milner (1988). Resisting Protectionism: Global Industries and the Politics of International Trade. Princeton: Princeton University Press. 
Helpman, E. and P. Krugman (1985), Market Structure and Foreign Trade, (Cambridge MA: The MIT Press).

Hillman, A. (1989). The Political Economy of Protection. Harwood Academic Publishers, Chur, London and New York, 1989, 2nd printing 1994; 3rd printing 2001 (hardcover) Routledge, London.

Hillman, A. (1989). The Political Economy of Protection. Harwood Academic Publishers, Chur, London and New York, 1989, 2nd printing 1994; 3rd printing 2001 (hardcover) Routledge, London.

Hiratsuka, Daisuke (2005). "Vertical Intra-Regional Production Networks in East Asia: A Case Study of Hard Disc Drive Industry," IDE working paper.

Hoekman, Bernard and Kostecki, Michel (2001). The Political Economy of the World Trading System: The WTO and Beyond, Oxford University Press, Oxford.

Hoekman, Bernard, and Michel Kostecki, 1995, The Political Economy of the World Trading System, Oxford: Oxford University Press.

Hufbauer, G. (1989). Background Paper for The Free Trade Debate, Reports of the $20^{\text {th }}$ Century Fund Task Force on the Future of American Trade Policy, Priority Press, New York.

Hufbauer, G. and R. Baldwin (2006), 'The Shape of a Swiss-US Free Trade Agreement', Policy Analyses in International Economics 76 (Washington DC: Institute for International Economics).

Hufbauer, G.C., J.S. Erb and H.P. Starr (1980). "The GATT codes and the undconditional most-favoured nation principle," Law and Policy in International Business, no.1.

Hufbauer, H, J. Schott, and D. Clark (1994), Western Hemisphere Economic Integration, (Washington: Institute for International Economics).

Irwin, D. (1996). Against the Tide: An Intellectual History of Free Trade, Princeton University Press.

Jackson, John H. (1997) The World Trading System: Law and Policy of International Economic Relations. 2d ed. Cambridge: MIT Press, 1997.

JETRO (2003). "Current Status of AFTA and Corporate Responses," November, JETRO, Japan.

John H. Jackson (2000). The World Trade Organization: Watershed Innovation or Cautious Step Forward?' in John H. Jackson, ed., The Jurisprudence of the GATT \& the WTO: Insights on Treaty Law and Economic Relations (Cambridge: Cambridge University Press).

John H. Jackson '(2000). The World Trade Organization: Watershed Innovation or Cautious Step Forward?' in John H. Jackson, ed., The Jurisprudence of the GATT \& the WTO: Insights on Treaty Law and Economic Relations, Cambridge University Press.

Kajita, A. (2004). “The Influence on Japanese Companies by East Asian FTAs, and an Overview of East Asian Countries' Tariff Rates," IDE APEC Study Center, Working Paper Series 03/04 - No. 5.

Kaplan, E. (1996), American Trade Policy: 1923-1995. (Westport, CT: Greenwood Press).

Kenen, P. (1989), The International Economy, Second Edition. (New York: Prentice-Hall).

Keohane, Robert D. (2002), Power and Governance in a Partially Globalized World, London: Routledge.

Kimura, Fukunari and Ando, Mitsuyo (2003a) "Fragmentation and Agglomeration Matter: Japanese Multinationals in Latin America and East Asia." North American Journal of Economics and Finance Vol. 14 (3).

Kimura, Fukunari and Ando, Mitsuyo (2003b) "Intra-regional Trade among China, Japan, and Korea: Intra-industry Trade of Major Industries." In Yangsen Kim and Chang Jae Lee, eds., Northeast Asian Integration: Prospects for a Northeast Asian FTA. Seoul: KIEP: 245-279.

Kimura, Fukunari and Ando, Mitsuyo (2004) "Two-dimensional Fragmentation in East Asia: Conceptual Framework and Empirics". Forthcoming in the special issue, 'Outsourcing and Fragmentation: Blessing or Threat?', of International Review of Economics and Finance.

Kindleberger, C. (1989), 'Commercial policy between the wars'. In P. Mathias and S. Pollard (eds), Cambridge Economic History of Europe, Volume VII, (Cambridge: Cambridge University Press).

Krishna, P. (1998). "Regionalism and Multilateralism: A Political Economy Approach," Quarterly Journal of Economics, February 1998, Vol. 113, No. 1, Pages 227-250.

Krueger, A. (1993), 'Free trade agreements as protectionist devices: Rules of origin,' NBER WP 4352, (Cambridge MA).

Krugman, P. (1980), 'Scale Economies, Product Differentiation, and the Pattern of Trade', American Economic Review, Vol. 70, No. 5, pp. 950-959.

Krugman, P. (1995). Growing world trade: causes and consequences. Brooking Papers on Economic Activity, 25th Anniversary Issue, 327-377.

Krugman, Paul (1993), 'Regionalism versus multilateralism: Analytic notes', in De Melo, J. and Panagariya, A. (eds), New dimensions in regional integration, (Cambridge: CambridgeUniversity Press for CEPR).

Kuchiki, A. (2003). "Agglomeration and exporting firm in industrial zones in Northern Vietnam: Players and Institutions," in M. Kagami and M. Tsuji (eds), Industrial Agglomeration, IDE-JETRO 2003, Tokyo.

Lamy, P. , H. Dieter , J. Defraigne, R. Higgott (2006), 'Report on East Asian Integration: Opportunities and Obstacles for Enhanced Economic Co-operation' www.notre-europe.asso.fr (Paris: Notre Europe).

Lawrence, R. (1996), Regionalism, multilateralism and deeper integration, (Washington: Brookings Institute).

Levy, Philip, 1997, “A political-economic analysis of free-trade agreements," American Economic Review, Vol. 87, pp. 506519.

Lijun, Sheng (2003). "China-ASEAN Free Trade Area: Origins, Developments and Strategic Motivations,” ISEAS Working Paper, Series No. 1(2003). http://bookshop.iseas.edu.sg.

Magee, Chris, 2002, "Declining industries and persistent protection," Review of International Economics, Vol. 10.

Markusen, J. (1981)

Markusen, J. (1981), 'Trade and the gains from trade with imperfect competition', Journal of International Economics, vol. 11, 4, 531-551.

Matsuyama, Kiminori, 1990, "Perfect equilibria in a trade liberalization game," American Economic Review, Vol. 80, pp. 480492. 
Mclaren, J. (2002) A Theory of Insidious Regionalism. Quarterly Journal of Economics 117:2, 571-608.

Melitz, M. (2003), 'The Impact of Trade on Intra-Industry Reallocations and Aggregate Industry Productivity', Econometrica, vol. 71(6), pages 1695-1725, November.

Michael Gilligan (1997). Empowering Exporters: Reciprocity, Delegation and Collective Action in American Trade Policy. Ann Arbor: University of Michigan Press.

Milner, H. (1988), Resisting Protectionism: Global Industries and the Politics of International Trade (Princeton, NJ: Princeton University Press).

Nell, P. (1999). "WTO negotiations on the harmonization of rules of origin : a first critical appraisal." Journal of World Trade, 33 , no. 3 , p. $45-71$.

$\mathrm{Ng}$, F. and Yeats, A. (2003). Major trade trends in East Asia: what are their implications for regional cooperation and growth?. World Bank Policy Research Working Paper 3084. The World Bank.

Panagariya (1996), 'APEC and the United States,' CIES DP, (University of Adelaide).

Panagariya A (1999). “The Regionalism Debate: An Overview.” The World Economy, Volume 22, Number 4, June 1999, pp. 455-476.

Panagariya, A. (2000). "Preferential Trade Liberalization: The Traditional Theory and New Developments," Journal of Economic Literature, vol. 38(2), pages 287-331, June.

Preeg, Ernest (1970). Traders and Diplomats: An Analysis of the Kennedy Round under the General Agreement on Tariffs and Trade, Brookings Institution, Washington D.C.

Sapir, A. (1997),'Domino effects in Western European Trade, 1960-1992,' CEPR DP (London).

Schott, J. (1988), 'The free trade agreement: A US assessment' in J. Schott and M. Smith (eds), The Canada-US free trade agreement: The global impact, (Washington: Institute for International Economics).

Schott, J. (1989), 'More free trade areas?' in J. Schott (ed.), Free trade areas and US trade policy, (Washington: Institute for International Economics).

Schott, J. and G. Hufbauer (1992), 'NAFTA: Questions of form and substance,' in Waverman, L. (ed.), Negotiating and implementing a North American free trade agreement, (Vancouver: The Fraser Institute).

Serra et al. (1997), Reflections on regionalism: Report of the study group on international trade, (New York: Carnegie Endowment for International Peace).

Smith, M. (1988), 'The free trade agreement in context: A Canadian perspective,' in The Canada-United States free trade agreement: The global impact (Washington: Institute for International Economics).

Staiger, Robert W. (1995). "A Theory of Gradual Trade Liberalization,” in Jim Levinsohn, Alan V. Deardorff, and Robert M. Stern, New Directions in Trade Theory, Ann Arbor, The University of Michigan Press.

Summers, L. (1991), 'Regionalism and the world trading system,' in L.Summers (ed.) Policy implications of trade and currency zones, Federal Reserve Bank of Kansas City.

USTR (1981), North American Trade Agreements, (Washington: Ofice of the US Trade Representative).

Viner, J. (1950), The Customs Union Issue, (New York: Carnegie Endowment for International Peace).

Whalley, J. (1993), 'Regional trade arrangements in North America: CUSTA and NAFTA,' in De Melo, J. and Panagariya, A. (eds), New dimensions in regional integration, (Cambridge: CambridgeUniversity Press for CEPR).

Whalley, J. (1996), 'Why do countries seek regional trade agreements?', NBER WP 5552 (Cambridge MA)

Whalley, John and O G Dayaratna Banda (2005). "Beyond Goods and Services: Competition Policy, Investment, Mutual Recognition, Movement of Persons, and Broader Cooperation Provisions of Recent FTAs Involving ASEAN Countries," University of Western Ontario, Center for International Governance and Innovation (CIGI) manuscript, March 2005.

Winters, A. (1996), 'Regionalism versus multilateralism,' World Bank PolicyResearch Working Paper 1687, (Washington).

Winters, L. Alan, 1996. "Regionalism versus multilateralism," Policy Research Working Paper Series 1687, The World Bank.

Wolf, M. (1994), The Resistable Appeal of Fortress Europe (Washington: American Enterprise Institute)

Wonnacott, P. (1987), The United States and Canada: The quest for free trade, (Washington: Institute for International Economics).

World Bank (2000), Trade Blocs, (Oxford: Oxford University Press).

WTO (1995), Regionalism and the world trading system (Geneva: WTO Secretariat)

WTO (1999). "High Level Symposium on Trade and Development: Background Document," Development Division.

WTO (2003), Annual Report, (Geneva: World Trade Organisation).

WTO (2004), International Trade Statistics, (Geneva: World Trade Organisation).

WTO (2005), International Trade Statistics, (Geneva: World Trade Organisation).

WTO (2005), World Trade Report (Geneva: World Trade Organisation).

Yamamoto, Gen (2002). "Theoretical Considerations of Multilateralism and Regionalism," Working Paper Series 01/02 - No. 2,IDE APEC Study Center. http://www.ide.go.jp/English/Publish/Apec/pdf/apec13_wp2.pdf

Yeats, S. (1997), 'Does Mercosur's trade performance raise concerns about the effects of regional trade arrangements' World Bank Policy Research WP 1729 (Washington).

Yi, S. (1996), 'Endogenous formation of customs unions under imperfect competition: Open regionalism is good,' Journal of International Economics, 41, 151-175.

Zeiler, T. (1997). “GATT Fifty Years Ago: U.S. Trade Policy and Imperial Tariff Preferences,” Business and Economic History, Vol. 26, No.2, Winter.

Zissimos, Ben \& Ben Lockwood, 2004. "The GATT and Gradualism," Econometric Society 2004 North American Summer Meetings 607, Econometric Society. 


\section{APPENDIX}

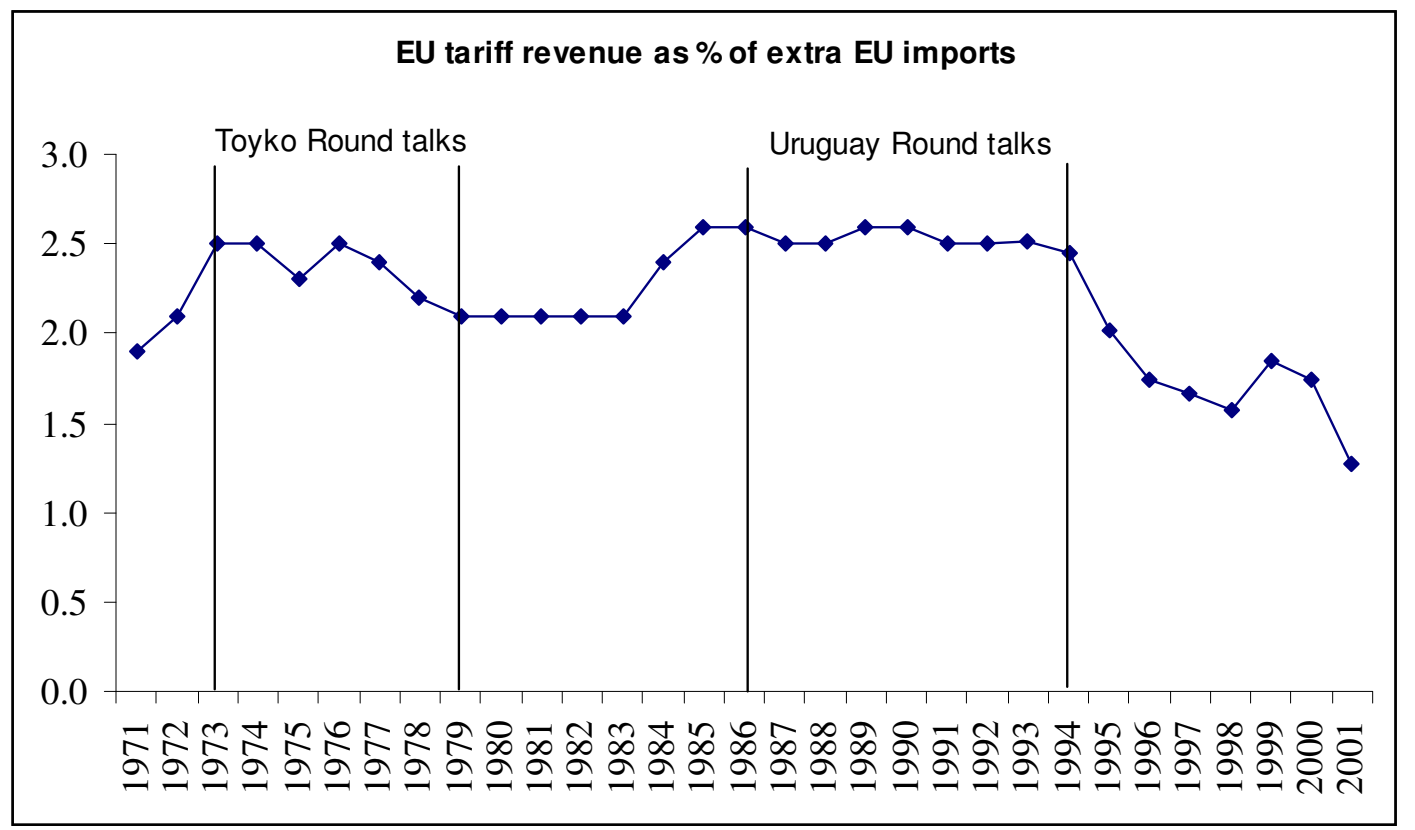

Figure 14: EU average tariff rate, 1971-2003.

Note: EU membership (and with it, the composition of EU imports) changed in 1973, 1981, 1986 and 1995. For most of this period, much of the EU tariff revenue came from agriculture variable levies which were adjusted to maintain a given domestic price. The protectionist element of the variable levy tended to rise over the 1970s and 1980s, but also fluctuated with world food prices. The system was reformed massively with the MacSharry reform which was implemented in 1994 (in tandem with the Uruguay Round conclusion).

Source: Michael Finger. 


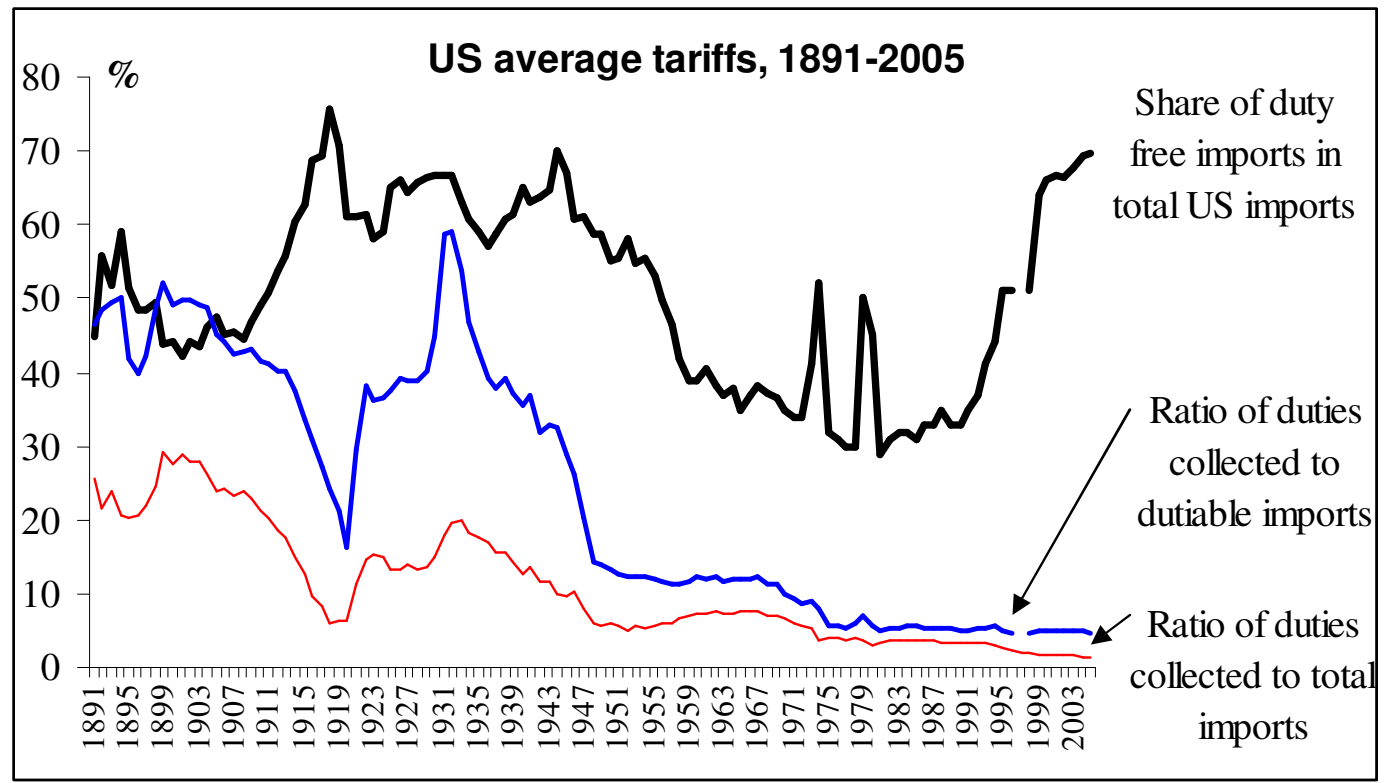

Figure 15: US average tariff; \% of dutiable and total imports, 1891-2005.

Note: The US did not collect tariffs on imports for which there was no domestic supplier e.g. coffee (Doug Irwin provided this insight). Up to 1950, almost $60 \%$ of US imports consisted of such duty-free raw materials; $30 \%$ in 1980s as the US shifted towards intra-industry trade in manufactures, but it has recently risen to $70 \%$ as a result of multilateral, regional and unilateral tariff cutting. Michael Finger provided this additional proviso: "The decline in the US average nominal tariffs on dutiable imports between 1938 and 1947 was largely unintended. The sharp rise in price level and the widespread use of specific duties caused a marked decrease in nominal tariffs between 1938 and 1947. (Between 1938 and 1948 primary commodity prices went up by $172 \%$ and those of manufactured goods by $100 \%$ according to Gatt International Trade 1952."

Source: Michael Finger. 